\title{
Learning from international internships : a reconstruction in the medical domain
}

Citation for published version (APA):

Niemantsverdriet, S. (2007). Learning from international internships : a reconstruction in the medical domain. [Doctoral Thesis, Maastricht University]. Datawyse / Universitaire Pers Maastricht. https://doi.org/10.26481/dis.20070626sn

Document status and date:

Published: 01/01/2007

DOI:

10.26481/dis.20070626sn

Document Version:

Publisher's PDF, also known as Version of record

\section{Please check the document version of this publication:}

- A submitted manuscript is the version of the article upon submission and before peer-review. There can be important differences between the submitted version and the official published version of record.

People interested in the research are advised to contact the author for the final version of the publication, or visit the DOI to the publisher's website.

- The final author version and the galley proof are versions of the publication after peer review.

- The final published version features the final layout of the paper including the volume, issue and page numbers.

Link to publication

\footnotetext{
General rights rights.

- You may freely distribute the URL identifying the publication in the public portal. please follow below link for the End User Agreement:

www.umlib.nl/taverne-license

Take down policy

If you believe that this document breaches copyright please contact us at:

repository@maastrichtuniversity.nl

providing details and we will investigate your claim.
}

Copyright and moral rights for the publications made accessible in the public portal are retained by the authors and/or other copyright owners and it is a condition of accessing publications that users recognise and abide by the legal requirements associated with these

- Users may download and print one copy of any publication from the public portal for the purpose of private study or research.

- You may not further distribute the material or use it for any profit-making activity or commercial gain

If the publication is distributed under the terms of Article $25 \mathrm{fa}$ of the Dutch Copyright Act, indicated by the "Taverne" license above, 


\section{Learning from International Internships}

A Reconstruction in the Medical Domain 
Dit onderzoek werd uitgevoerd in het kader van het Interuniversitair Centrum voor Onderwijsonderzoek.

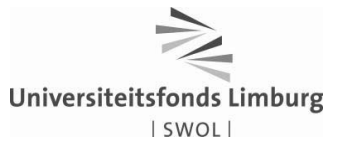

Dit onderzoek werd mede mogelijk gemaakt door een reiskosten subsidie van het Universiteitsfonds Limburg / SWOL.

Cover photo: Susan Niemantsverdriet

Cover design: Datawyse Maastricht

Printing: Datawyse / Universitaire Pers Maastricht

ISBN 9789052786292

(C) Taylor \& Francis Ltd, Chapters 2 and 5

(C) Blackwell Science Ltd, Chapters 3 and 4

(C) Susan Niemantsverdriet, other Chapters 


\title{
Learning from International Internships A Reconstruction in the Medical Domain
}

\author{
PROEFSCHRIFT \\ ter verkrijging van de graad van doctor \\ aan de Universiteit Maastricht, \\ op gezag van de Rector Magnificus, \\ Prof. mr. G.P.M.F. Mols, \\ volgens het besluit van het College van Decanen, \\ in het openbaar te verdedigen \\ op dinsdag 26 juni 2007 om 14.00 uur \\ door \\ Susanna Niemantsverdriet
}

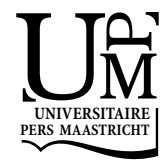




\section{Promotores}

Prof. dr. C.P.M. van der Vleuten

Prof. dr. A.J.J.A. Scherpbier

\section{Copromotor}

Dr. G.D. Majoor

\section{Beoordelingscommissie}

Prof. dr. G.G.M. Essed (voorzitter)

Prof. dr. H.P.A. Boshuizen, Open Universiteit Nederland Prof. dr. G.J. Dinant

Dr. T. de Goeij

Prof. dr. M.C. van der Wende, Universiteit Twente 


\section{Table of Contents}

1 Introduction $\quad 7$

2 Internationalization of medical education in the Netherlands: $\quad 17$ State of affairs.

Published in Medical Teacher 2006;28:187-189.

3 What do students learn?

Published in Medical Education 2004;38:749-757.

4 Students' perceptions of their learning processes.

Published in Medical Education 2005;39:1236-1242.

5 Foreign supervisors' perceptions of students' learning processes.

Published in Medical Teacher 2006b;28:e104-e111.

6 What should be learning outcomes?

Submitted.

7 Towards a Grounded Theory of learning in international internships.

Submitted.

8 Conclusion and discussion $\quad 97$

$\begin{array}{ll}\text { Summary } & 107\end{array}$

Samenvatting 113

Dankwoord 119

$\begin{array}{ll}\text { Curriculum Vitae } & 121\end{array}$ 



\section{Chapter 1}

\section{Introduction}

The subject of this thesis is students' learning from international internships. Learning from international internships is part of the turbulent field of internationalisation of higher education. In a short historical overview, the main developments in internationalisation of higher education will be sketched. Subsequently, we will discuss why the field of medical education has to pay attention to internationalisation of education. The problem definition of the research reported in this thesis is presented and the research methodology discussed. This introductory chapter ends with an overview of the studies that together constitute this thesis.

\section{Background to the Research}

\section{Short History of Internationalisation of Education}

Today, internationalisation of higher education is going through a process of rapid change. Until the twentieth century the international dimension of higher education was rather incidental and individual. Characteristic manifestations include the wandering student and scholar, and student flows from less developed to highly developed countries. The export of higher education models in the eighteenth and nineteenth century might be viewed as academic colonialism rather than internationalisation of higher education. Around and after the Second World War international education activities became more structurally embedded within educational programmes, especially in the United States and to a large extent driven by the Cold War. Undergraduate education was the main focus of these activities, which were motivated by political rationales of national security and foreign policy, like promoting peace and international understanding. From the 1960s until the 1980s the dominant international programmes in Canada, Australia, and the Netherlands focused on 'technical assistance and 
development cooperation'. During the same period the international flow of students mainly from south to north expanded. ${ }^{1}$

The 1980s started to see major changes in internationalisation of education in Europe. In 1976 the Council of the European Communities adopted an action programme for education. From the rationales of this plan the issues emerged that have continued to dominate European education policies until today: harmonisation, Europeanisation and globalisation. ${ }^{1}$

In 1987 the ERASMUS programme was launched by the European Commission. This programme was directed at mobility and cooperation on education in Europe. Student mobility has been the most prominent feature of the programme from the outset, with more than half of the funding going to student mobility grants. One of the results of this programme has been that a large component of internationalisation in education changed from traditional vertical mobility, i.e. student flows from the less favoured to the most privileged countries and prestigious institutions, to exchange of students on equal terms, based on partners' mutual trust in the quality of their higher education provisions. Additional actions of the ERASMUS programme provided support for teaching staff exchange and curricular innovations. In 1995 the ERASMUS programme was incorporated into SOCRATES; the umbrella programme of the European Union for educational activities. ${ }^{2}$ Since the launch of the ERASMUS programme many institutions of higher education have established offices of international relations. It has become the trend for institutions to give internationalisation a central place in their mission statements, strategy plans and budgets. ${ }^{1}$

Education was covered by the Maastricht Treaty of 1992, with issues like the development of a European Credit Transfer System (ECTS) within the ERASMUS/SOCRATES framework and recognition of diplomas. In the 1990s a broad range of programmes and activities was introduced to promote the European dimension in higher education, such as research \& development programmes, mobility of staff and students, curriculum development and network building. ${ }^{1}$ At the turn of the century, in 1999, the Bologna Declaration was signed. It envisaged the creation of a European space for Higher Education, which was to be completed by 2010 . The Bologna Declaration has been signed by 29 European countries (including the Netherlands). The main objectives are to increase transparency and enhance international competitiveness of European higher education by means of the introduction of an undergraduate-graduate system. ${ }^{3}$

Within Europe the Bologna process is linked to a shift from cooperation to competition. With the demand for higher education increasing worldwide, the transnational delivery of higher education becomes big business in some areas. Another increasingly strong impact on higher education is that of economic globalisation. This development paves the way for global definitions of the quality of education, based on benchmarking and well-defined quality criteria. The Bologna process has introduced an explicit international dimension into European 
higher education, with strong implications for quality assurance at the national level. ${ }^{4}$

There is considerable discrepancy in the terms used in relation to internationalisation of education. Definitions by American authors generally emphasise activities, rationales, competencies and/or ethics, and they use the term 'international education'. 'International education' is used in diverse ways and its main focus is on primary and secondary education rather than on higher education, development education, and/or country studies. Authors from Europe, Canada, and Australia tend to favour a process approach and use the term 'internationalisation of higher education'. The most widely cited and accepted process definition of 'internationalisation of higher education' is the one by Jane Knight (1993). ${ }^{1}$ She defined internationalisation of higher education as: 'The process of integrating an international/intercultural dimension into the research, teaching and services function of higher education'.

\section{Medical Education and Internationalisation of Education}

In medical education, internationalisation has been slow to develop. An important topic at the conference on "ERASMUS and Mobility in Medical Studies" which was held in Brussels in November 1991 was why participation of medical students in European student and teacher exchange programmes did not reflect the size of the profession and the number of persons in medical training. At that time, medical students accounted for $15 \%$ of the student population in the then twelve member states of the European Community, whereas only 3\% of ERASMUS mobility students were medical students. ${ }^{6}$ Awareness of later developments relating to the Bologna process was also considered by some to be rather limited in medical schools. ${ }^{7}$ However, at the beginning of the new century, standardisation of medical education was a topic of lively debate at conferences and in medical journals ${ }^{8-10}$ and universities developed Bachelor/Master programmes in medicine (e.g. in the Netherlands: Groningen University Medical School started a Bachelor/Master programme in 2005-2006 and Maastricht University medical school in study year 2006-2007).

Medical education was also pressed to pay attention to internationalisation because of issues pertaining to globalisation. ${ }^{9,11,12}$ Globalisation is recognised as an important factor in the field of medicine. Globalisation, through the exchange of people, services and commodities all over the world, affects the health of populations and the delivery of health care worldwide. ${ }^{13,14}$ To some extent these issues can be addressed by internationalisation of education, such as internationalisation of the curriculum, student mobility and staff mobility. ${ }^{1,5}$ Thus far student mobility (students going abroad for part of their training) has been the most popular approach to internationalisation in education. ${ }^{2}$ 
In the medical education literature the effects of student mobility have received scant attention. A few publications addressed the potential dangers of international internships, like moral dilemma's ${ }^{15}$ and risk of infections. ${ }^{16,17}$ Thompson et al. (2003) ${ }^{18}$ evaluated the educational effects of international clinical electives or rotations by reviewing studies reported in Medline and ERIC databases between 1966-2000. The eight studies they selected were conducted among medical students (three studies), residents (two studies) or combinations of medical students and residents (three studies). One conclusion was that international clinical electives and rotations had educational benefits in respect of participants' knowledge, skills, and attitudes, and another conclusion was that learning from international internships remained to be examined further. The implications of the conclusions were constrained by extensive variation among the electives and rotations studied in duration, types, and preparation as well as by the not so very strong study designs of the studies. ${ }^{18}$

\section{General Problem Definition}

Historical and political developments, like the unification of Europe, globalisation and steadily increasing internationalisation activities, forced medical educationalists to pay attention to issues of internationalisation. In the medical education literature, however, attention for internationalisation of undergraduate medical education has been sparse and there is a lack of knowledge with regard to the educational effects of internationalisation.

When we embarked on the research for this thesis, the medical education literature had little to offer in terms of theoretical underpinnings for a study of internationalisation in medical education. Of course there is a considerable body of literature about learning in (clinical) practice, with extensive overviews by Onstenk (1997) ${ }^{19}$ and Dornan (2006) ${ }^{20}$, but at the start of our research it was not clear whether the theories discussed in those overviews, like those of Kolb $(1984)^{21}$ or Schön $(1987)^{22}$, were applicable also to learning during international internships. The studies reviewed by Thompson et al $(2003)^{18}$ did not present clear signposts for explorations in that direction either. Because of this lack of theoretical background we formulated a general research question that allowed holistic and inductive exploration of internationalisation in medical education. The general research question at the centre of this thesis is: 'What are the educational effects of internationalisation of education for learning in the undergraduate medical curriculum?

To answer this general question, we formulated more specific research questions. Our first study revealed that outbound student mobility was the trait of internationalisation that was shared by most of the Dutch medical schools. Hence we decided to focus our research efforts on international internships. The 
inductive nature of our research led us to continue to formulate specific subsequent research questions based on the findings of the studies we had completed. A motivation for each step in the research will be presented in the overview of the studies after the discussion of our methodological approach. The following specific research questions were addressed:

- Which aspects of educational internationalisation can be identified in the Dutch undergraduate medical curricula?

- What do medical undergraduate students learn from international internships?

- What is the nature of the learning process that takes place when undergraduate medical students undertake international internships?

- Do socio-cultural differences influence the nature of the learning process that takes place when undergraduate medical students undertake international internships?

- What should the learning outcomes of international internships for undergraduate medical students be?

The focus of the research is outbound student mobility, i.e. students going abroad for part of their training. The students that participated in the different studies can be characterised as 'free movers'. They did not apply for ERASMUS/SOCRATES grants and thus their choice of internship was not limited to regular study programmes or internships within Europe. The undergraduate medical students who participated in our studies undertook orientation electives, elective clerkships, regular clerkship rotations and research training electives all over the world. All these different international electives, rotations and other activities are referred to as international internships in this thesis.

\section{Nature of the Research}

\section{Research Method; a Qualitative Approach}

We chose a qualitative research approach to arrive at an answer to our general research question, because we wanted to explore holistically and inductively the educational effects of international internships. Grounded Theory was preferred over other qualitative research approaches because this methodology is directed at developing a well-integrated set of concepts that provides a theoretical explanation of a social phenomenon, grounded in data from the field. Other qualitative approaches seemed less useful because they are directed at understanding about matters like the essence of experiences about a phenomenon (phenomenology) or describing and interpreting a particular cultural and social group (ethnography). ${ }^{23}$ 


\section{Origin and Paradigmatic Location of Grounded Theory}

In their pre-eminent treatise The discovery of Grounded Theory: Strategies for qualitative research (1967) ${ }^{24}$ Glaser and Strauss laid the foundation for Grounded Theory. Many elaborations of this original work followed, including publications by Strauss (1987) ${ }^{25}$ and Strauss and Corbin (1998). ${ }^{26-28}$

Initially, Grounded Theory took a traditional positivist position, based on the assumption of an objective, external reality. Strauss and Corbin $(1998)^{26}$ moved to a post positivist position, still assuming an objective, external reality, but also acknowledging how respondents' views of reality might conflict with their own views. Charmaz $(2000)^{29}$ elaborated Grounded Theory in a constructivist way. Charmaz $(2000)^{29}$ "assumes the relativism of multiple social realities, recognises the mutual creation of knowledge by the viewer and the viewed, and aims at interpretive understanding of subjects' meanings."

In this thesis, Grounded Theory has been used as a heuristic strategy, aimed at constructing theoretical frameworks to explain the collected data. Another aim was to reconstruct, understand and interpret the realities of the research subjects. In this (pragmatic) way we joined the post positivist approach and the constructive approach. ${ }^{30}$

\section{Grounded Theory Methodology}

Grounded theory is a research methodology designed to develop, through collection and analysis of data, a well-integrated set of concepts that provide a theoretical explanation of a social phenomenon. It involves cycles of simultaneous data collection and analysis, in which the results of ongoing data analysis inform subsequent data collection. Grounded Theory methodology starts with an exploratory phase characterised by 'open coding' of data to discover categories. A second level coding process, called 'axial coding', explores and defines connections between central categories. On a further level a 'core category' is determined, which makes the other categories 'work'. In this final phase the Grounded Theory is elaborated. The cycle of data collection-analysis-reflection takes place iteratively over the course of the Grounded Theory trajectory. Data collection is not restricted to specific modalities and data are primarily, but not exclusively, qualitative. ${ }^{25,26,28,31}$

We used the Grounded Theory methodology in all parts of the research, with 'open coding' and 'axial coding' phases being conducted continuously to build frameworks to explain the collected data. Our final study can be seen as a prelude to the final phase of Grounded Theory methodology. We present an integrated set of concepts based on our findings, explaining the research problem concerning internationalisation of medical education in a preliminary Grounded Theory. 


\section{Overview of the Studies}

In Chapter 2 our exploration starts with an electronic survey of internationalisation in the Dutch medical schools. The themes of the questionnaire we administered to the internationalisation coordinators were: aspects of internationalisation in the medical curricula; quantity and nature of student mobility; quality assurance policies. A feature of internationalisation that proved to be shared by all the medical schools was the dominance of outbound student mobility.

Outbound student mobility, i.e. international internships, is the focus of the exploration in Chapter 3. This study reports the results of in depth interviews with undergraduate medical students about their learning experiences during international internships. The students reported a range of meaningful outcomes as well as a range of problems encountered during their internships. The variation between students in learning outcomes could not be explained by year of study, country visited or type of internship.

In Chapter 4 we try to explain the variation in learning outcomes that emerged from the previous study. We explore the learning processes of students on international internships. Categories distilled from interviews with students about their learning processes were: motivation, preparation, internal supervisor, external supervisor, assessment and positive and negative incidents. Some students reported that socio-cultural differences between them and their foreign supervisors constituted a barrier to productive learning. It appeared highly likely that students' learning processes explained a large part of the variation in their learning outcomes.

In Chapter $\mathbf{5}$ we explore students' learning processes again, this time by interviewing foreign supervisors of Dutch students in a case study design. The three cases addressed the effects of potential socio-cultural differences between the Dutch context and three different contexts of elective sites: 1. outback Australia; 2 urban Australia; 3 non-western countries. The findings were largely consistent with those of the study reported in chapter 4: students' learning processes were largely unstructured; 'experiential learning processes' prevailed, and productive learning was occasionally hampered by socio-cultural differences.

In Chapter 6 we argue that bringing more structure to students' learning processes might enhance the educational effectiveness of international internships. One way of structuring learning processes is to define learning outcomes. This requires a framework of desired learning outcomes for international internships. As a starting point for developing such a framework we used the one we developed in Chapter 2 to organise the learning outcomes reported by the students. A Delphi-study among an international panel refined and validated this framework. In Chapter 7 the findings of the studies are synthesised in a preliminary Grounded Theory. We present a well integrated set of concepts which together elucidate students' learning on international internships. 
In Chapter 8 the main conclusions of the studies are discussed and recommendations for future research are made.

In chapters 2-7 the studies we conducted are reported in detail. Because these studies were written to be published as separate articles, some overlap of content is inevitable.

\section{References}

1. De Wit JWM. Internationalisation of higher education in the United States of America and Europe. Amsterdam: University of Amsterdam PhD Thesis, 2001.

2. Teichler U. Changes of ERASMUS under the umbrella of SOCRATES. Journal of Studies in International Education 2001;5:201-227.

3. Van der Wende MC. Globalisation and access to higher education. Journal of Studies in International Education 2003;7:193-206.

4. Campbell C, van der Wende MC. International initiatives and trends in Quality Assurance for European Higher Education. Exploratory trend report. Helsinki: The European Network for Quality Assurance in Higher Education, 2000.

5. Knight J. Monitoring the quality and progress of internationalisation. Journal of Studies in International Education 2001;5:228-43.

6. Bourgeois M. ERASMUS and mobility in medical studies. Report of the conference in Brussels, November 22 and 23, 1991. University of Düsseldorf: Commission of the European Communities, 1992.

7. Christensen L. The Bologna process and medical education. Medical Teacher 2004;26:625629.

8. Ten Cate O, Karle H. Point: Global standards in medical education - what are the objectives? Counterpoint: Global standards in medical education - an instrument in quality improvement. Medical Education 2002;36:602-605.

9. Karle H. Spotlight on globalization and international standards. In: Take-home messages from AMEE 2004 in Edinburgh. Medical Teacher, 2004;26:741-742.

10. Prideaux D. Think global, act regional: promoting change in medical education. (Editorial) Medical Education 2005;39:765-757.

11. Edwards R, Rowson M, Piachaud J. Teaching international health issues to medical students. Medical Education 2001;35:807-8.

12. Eckhert NL. The global pipeline: too narrow, too wide or just right? Medical Education 2002;36:606-13.

13. Unwin E, Alberti G, Aspray T, Edwards R, Mbanya J, Sobngwi, Mugusi F, Rashid S, Setel P, Whiting D. Economic globalisation and its effect on health. British Medical Journal 1998;316:1401-2.

14. Bateman C, Baker T, Hoornenborg E, Ericsson U. Bringing global issues to medical teaching. Lancet 2001;358:1539-42.

15. Banatvala N, Doyal, L. Knowing when to say "no" on the student elective. British Medical Journal 1998;316:1404-1405.

16. Wilkinson D, Symon B. Medical students, their electives, and HIV. British Medical Journal 1999;318:139-140.

17. Moss PJ, Beeching NJ. Provision of health advice for UK medical students planning to travel overseas for their elective study period: questionnaire survey. British Medical Journal 1999;318:161-162. 
18. Thompson MJ, Huntington MK, Hunt DD, Pinsky LE, Brodie JJ. Educational effects of international health electives on US and Canadian medical students and residents: A literature review. Academic Medicine 2003;78:342-7.

19. Onstenk J. Lerend leren werken. Brede vakbekwaamheid en de integratie van leren, werken en innoveren. (Learning to learn working.) Delft: Eburon, 1997, PhD Thesis.

20. Dornan T. Introduction. In: Experience based learning. Learning clinical medicine in workplaces. Dornan T. Maastricht: Datawyse, 2006, PhD Thesis.

21. Kolb DA. Experiential learning. Englewood Cliffs: Prentice-Hall, 1984.

22. Schön DA. Educating the reflective practitioner. Toward a New Design for Teaching and learning in the professions. San Francisco: Jossey Bass, 1987.

23. Creswell JW. Qualitative inquiry and research Design: Choosing among five traditions. Thousand Oaks, CA: Sage Publications, 1998.

24. Glaser BG, Strauss A. The discovery of Grounded Theory: Strategies for qualitative research. Chicago: Aldine Transaction, 1967.

25. Strauss A. Qualitative Analysis. New York: Cambridge University Press, 1987.

26. Strauss A, Corbin J. Basics of qualitative research, techniques and procedures for developing grounded theory. Newbury Park: Sage Publications, 1998, Second Edition.

27. Harris I. What does "The Discovery of Grounded Theory" have to say to medical education? Advances in Health Sciences Education 2003;8: 49-61.

28. Kennedy TJT, Lingard LA. Making sense of grounded theory in medical education. Medical Education 2006;40:101-108.

29. Charmaz K. Grounded Theory: objectivist and constructivist methods In: Denzin NK, Lincoln YS. (Eds) Handbook of Qualitative Research. Thousand Oaks, CA: Sage Publications, 2000.

30. Lincoln YS, Guba EG. Paradigmatic controversies, contradictions and emerging confluences. In: Denzin NK, Lincoln YS. (Eds) Handbook of Qualitative Research. Thousand Oaks, CA: Sage Publications, 2000.

31. Wester F. Strategieën voor kwalitatief onderzoek. (Strategies for qualitative analysis.) Bussum: Coutinho, 1987. 



\title{
Chapter 2
}

\section{Internationalization of Medical Education in the Netherlands: State of Affairs ${ }^{1}$}

\begin{abstract}
In the framework of the Bologna Process, internationalisation co-ordinators of 7 (out of 8) Dutch medical schools completed an electronic survey about internationalisation-related aspects of the curriculum.

Common features of internationalization in Dutch medical schools were: the numbers of outgoing students exceeded the numbers of incoming students, and most international programmes involved clinical training and research projects. We recommend that Dutch medical schools should pay more attention to 'Internationalisation at Home' and focus on conditions that are conducive to participation by foreign students.
\end{abstract}

\footnotetext{
${ }^{1}$ This chapter has been pubished as: Niemantsverdriet S, Majoor GD, Scherpbier AJJA \& van der Vleuten CPM. Internationalisation of medical education in the Netherlands: state of affairs. Medical Teacher 2006;28:187-189.
} 


\section{Introduction}

In 1999, the Bologna declaration was signed by 29 European countries including the Netherlands. The main objectives of the declaration were to increase transparency and enhance international competitiveness of European higher education through the introduction of an undergraduate-graduate system. ${ }^{1}$ The position of medical education towards the Bologna Process is challenged, not in the least for reasons of quality assurance. ${ }^{2}$ To account for the state of affairs in the Netherlands and to invite others to do the same for their countries, we formulated the following research questions:

- Which aspects of internationalisation can be detected in the Dutch undergraduate medical curricula?

- What is the quantity and nature of student mobility at Dutch medical schools?

- How is the quality of study programs abroad maintained?

\section{Methods}

Internationalisation co-ordinators of Dutch medical schools were electronically surveyed about the state of affairs with regard to internationalisation in their medical school. ${ }^{3}$ Internationalisation of the curriculum was operationalised by five features of internationalisation: inclusion of courses in the regular medical curriculum given in English; inclusion of topics on (imported) tropical diseases; inclusion of topics on international health care systems; facilities for foreign language learning; facilities for skills training for dealing with patients from different cultural backgrounds. ${ }^{4}$

Closed questions were used to obtain data on quantity of student mobility, the countries of origin and destination of incoming and outgoing students respectively, divided into developing and industrialised countries, and the different types of study programs. The study programs were classified as regular courses, elective courses, clinical training or research projects. Open questions were related to quality assurance procedures.

The internationalisation co-ordinators of seven of the eight Dutch medical schools returned the completed questionnaire. Data were collected for the academic years 1998/1999 till 2000/2001. At the moment of data collection these were the latest available data. 


\section{Results}

\section{Internationalisation of the curriculum}

The situation with regard to the five features of internationalisation runs as follows.

Two schools have programs in the English language in their curricula and five have language teaching facilities for English or other languages.

Four schools offer electives in tropical medicine within the regular elective program. Two of the schools have integrated (imported) tropical diseases in the curriculum and one pays no attention to this subject.

Two schools offer electives that address communication with patients from different cultural backgrounds. One school has integrated a program in the regular curriculum, which addresses communication with patients from different cultural backgrounds. Four schools have not incorporated this feature in their curriculum.

International health care systems are included in the regular curriculum of one school. Three schools offer electives on international health care. Elsewhere the subject is not dealt with explicitly.

In addition to the features covered by the questions on internationalisation aspects, two schools mentioned their Summer Schools, which are attended by foreign students.

\section{Quantitative data on student mobility}

In the academic year 2000/2001, the average numbers of outgoing and incoming students per school were 107 (range 53-243) and 38 (range 12-77), respectively (table 1). The average number of outgoing students was stable over the three years studied (99, 104 and 107 in 1998/1999, 1999/2000 and 2000/2001, respectively). The average number of incoming students showed a slight increase over the years studied: from 27 in 1998/1999, to 38 in 2000/2001.

\section{Destinations of outgoing students and type of study program}

When we take the data of the seven schools together, the numbers of students going to industrialised and developing countries are very similar: 380 and 306. (However, the data vary considerably for the different schools.) Of the students going to industrialised countries, $59 \%$ participated in a research project, $32 \%$ did clinical training and $9 \%$ attended a course of the regular curriculum. Of the students going to developing countries, $70 \%$ took part in clinical training, $29 \%$ in a research project and only $1 \%$ attended a regular curricular course. 


\section{Countries of origin of the incoming students and type of study program}

The number of students from industrialised countries (219) greatly exceeds that of students from developing countries (47). Irrespective of the country of origin, the types of study programs are distributed evenly across the educational programs at the Dutch host schools. Out of the total of 266 incoming students, 79 $(30 \%)$ attended clinical training programs, $101(38 \%)$ regular (elective) courses and $86(32 \%)$ did research. (These percentages vary considerably across the schools as well.)

\section{Quality assurance in study programs abroad}

Measures and procedures for quality assurance are conducted by all seven schools with respect to study programs abroad, but differed in the way they are carried out. An example is the assessment of a students' performance abroad. It may be left entirely to the external supervisor of the study programs abroad, but more often the external supervisor's assessment is added to the assessment by the teacher(s) at the home university who are responsible for the final assessment. All schools require students to obtain permission from a teacher or committee of teachers before going abroad. For the assessment of a request to study abroad, the same quality standards are applied as those that apply for similar programs in the Netherlands.

\section{Discussion and conclusion}

The data may be considered representative for the Dutch situation. However, some internationalisation co-ordinators had difficulty producing the requested data because it was not readily available from databases. Categorization may have led to inconsistencies, for instance with categorizing the countries of destination and origin of students, into developing and industrialised countries. The distinction between the different educational options (clinical training, regular / elective courses, and research projects) is also not always very clear-cut, causing uncertainty about the appropriate category when the study program was not adequately defined when it was registered. Another constraint concerns the definition of incoming students. For instance students from abroad who participate in the regular medical curriculum as a whole were not included in this study, although it could be argued that they should have been.

The average numbers of outgoing students were stable in all medical schools for the three consecutive years studied. The average number of incoming students showed a slight increase over the course of the three years studied. Altogether there seems no indication for deviancy (in student mobility) in the study years used for this study. 
Taking account of these considerations the following conclusions can be drawn.

- All schools address some of the features of internationalisation in their curriculum. In many cases international study programs are offered as electives.

- In all schools, the numbers of outgoing students exceed the numbers of incoming students.

- All schools have some regulatory measures to ensure the quality of international internships.

The concept of 'Internationalisation at home' places a strong emphasis on the teaching and learning in a culturally diverse setting. ${ }^{5}$ From this viewpoint the lack of training with respect to dealing with patients from different cultural backgrounds in four of the medical schools, should be seen as a serious defect in the curriculum. All medical schools should include aspects of internationalisation in their regular curriculum and not just as electives. Another aspect in the development of 'Internationalisation at home' is that one might focus on the conditions that are conducive to participation by foreign students in medical education at a Dutch medical school. As a start by offering regular study programs in the English language. 


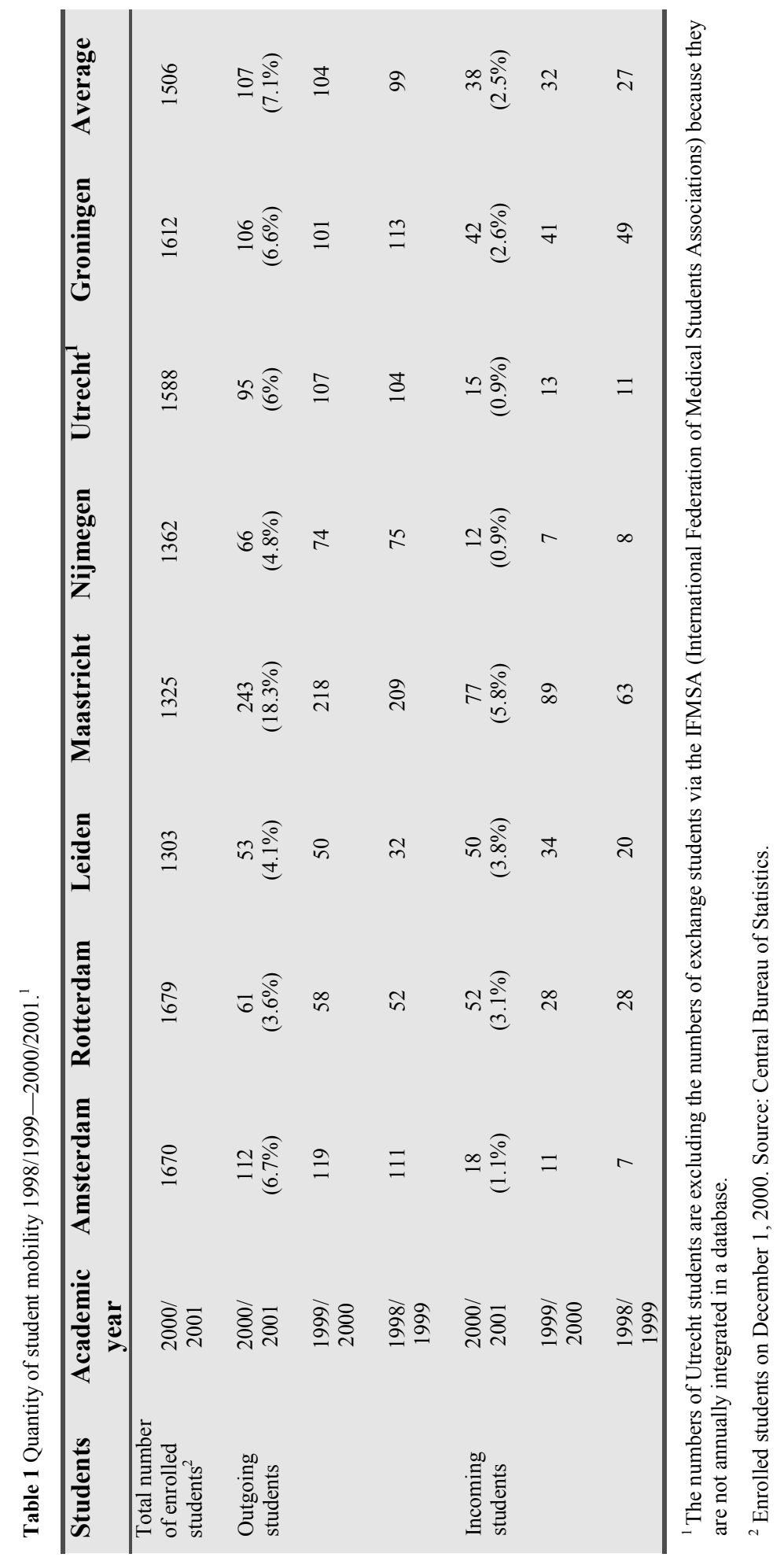




\section{References}

1. Van der Wende MC. Globalisation and access to higher education. Journal of Studies in International Education 2003;7:193-206.

2. Christensen L. The Bologna process and medical education. Medical Teacher 2004;26:625629.

3. Majoor GD, Niemantsverdriet S, Groen MM, ten Haven GEA, Hulstaert CE, Nijenhuis M, Vorstenbosch MATM, Willemstein SC. (2003) Internationalisering van het medisch onderwijs, de stand van zaken. (Internationalization of medical education: state of the art.) Tijdschrift Medisch Onderwijs (Dutch Journal of Medical Education), 2003;22:18.

4. Majoor GD, Willemstein SC. Internationalisering van het medisch onderwijs. (Internationalisation of medical education.) Nederlands Tijdschrijft Geneeskunde (Dutch Journal of Medicine), 1996;140:100.

5. Wächter B. An introduction: Internationalization at Home in context. Journal of Studies in International Education 2003;7:5. 



\title{
Chapter 3
}

\section{What do Students Learn? ${ }^{1}$}

\begin{abstract}
Objective: To explore learning outcomes from international internships for undergraduate medical students.

Method: In-depth interviews were conducted with 24 undergraduate medical students of the medical school of Maastricht University, the Netherlands. The 24 subjects were selected by purposeful sampling.

Results: Students reported meaningful learning outcomes on 6 domains: medical knowledge; skills; international health care organisation; international medical education; society and culture; personal growth.

Conclusion: International internships appear to provide good opportunities for students to meet requirements of globalisation as well as some generic objectives of undergraduate medical education.
\end{abstract}

\footnotetext{
${ }^{1}$ This chapter has been published as: Niemantsverdriet S, Majoor GD, Scherpbier AJJA \& van der Vleuten CPM. I found myself a down-to-earth Dutch girl: a qualitative study into learning outcomes from internships abroad. Medical Education 2004;38:749-757
} 


\section{Introduction}

Globalisation is recognised as a factor that affects the health of populations and the delivery of health care all over the world. ${ }^{1,2}$ Therefore medical education should pay attention to globalisation issues. ${ }^{3,4}$ This can be done by internationalisation of the curriculum, student mobility and staff mobility. ${ }^{5,6}$

Student mobility (i.e. students going abroad for part of their training) is the most common approach to internationalisation in education. ${ }^{7-9}$ A few studies have addressed what students learn from international internships. ${ }^{10,11}$ Although these studies described a variety of learning outcomes, the learning outcomes of international internships remain to be fully examined. ${ }^{11}$ The published studies were limited in scope, in that their measuring instruments were not well validated and addressed a limited quantity of variables, e.g. 'cultural sensitivity'. In order to obtain a broader view, we used a holistic and inductive approach to explore what medical undergraduate students learned from international internships (outcomes).

\section{Methods}

\section{Method}

Students' perceptions were explored using in-depth interviews. Data were collected and analysed by the constant comparative method, involving a cyclic, iterative process of 'data collection - analysis - reflection'. In that way analytical interpretations of the data focus further data collection and refine theoretical analysis. This approach resembles the 'Grounded Theory' method. ${ }^{12}$ It was chosen because it provides systematic inductive guidelines for collecting and analysing data (to build middle-range theoretical frameworks that explain the collected data. $)^{13}$

\section{Setting and subjects}

The context of this study is the medical school of Maastricht University, the Netherlands. The Maastricht undergraduate medical curriculum lasts six years, four years of predominantly theoretical education followed by two years of clerkships in hospitals and other healthcare settings. In year 3 students are offered an orientation elective, either in the Netherlands or abroad. In years 4-6 students can go abroad for one of the regular clerkship rotations, an elective clerkship or research training. In this study, all of the above-mentioned possibilities to go abroad are referred to as international internship. Students can select 
an international internship from a programme bank, but they are also free to arrange their own internship, provided approval is obtained from the Special Committee Elective Programmes of the Faculty of Medicine and from an internal supervisor (from Maastricht University). Students are assessed by the internal supervisor and by an external supervisor (at the internship site). In the academic year 2000/2001, 243 out of 1325 undergraduate medical students participated in an international internship. ${ }^{9}$

For this study, we used purposeful sampling to select 22 students who had completed an international elective in the academic years 2000/2001 and 2001/2002. ${ }^{14}$ Selection criteria were: year of study, type of internship, geographical area visited, discipline/topic of internship, sex and date of visit (one year or less after returning from the internship) (table 1). The principal author selected the students and invited them by telephone to participate in an interview; all invited students consented.

Two interviewees said that some of their fellow students had found their internships not as instructive as they had. Two students from these particular internship sites were added to the sample. They were willing to participate and were interviewed. This is considered theoretical sampling. ${ }^{13}$ In all, 24 students were interviewed.

Table 1 Overview of study sample. Distribution of students by different selection criteria $(n=24)$; numbers in brackets indicate absolute numbers of students.

\begin{tabular}{|c|c|c|c|c|}
\hline Sex & Study year & Type of internship & Geographical area & Specialty / topic \\
\hline $\begin{array}{l}\text { Male (10) } \\
\text { Female } \\
(14)\end{array}$ & $\begin{array}{l}\text { Year } 3(9) \\
\text { Year } 4(4) \\
\text { Year } 5(4) \\
\text { Year } 6(7)\end{array}$ & $\begin{array}{l}\text { Orientation elective } \\
\text { (11) } \\
\text { Research internship } \\
\text { (6) } \\
\text { Elective clerkship } \\
\text { (5) } \\
\text { Regular clerkship (2) }\end{array}$ & $\begin{array}{l}\text { Africa (6) } \\
\text { Asia (5) } \\
\text { Europe (3) } \\
\text { Middle East (3) } \\
\text { North America (2) } \\
\text { South America (4) } \\
\text { Oceania (1) }\end{array}$ & $\begin{array}{l}\text { Orthopaedics (1) } \\
\text { Gynaecology (3) } \\
\text { Surgery (3) } \\
\text { Paediatrics (3) } \\
\text { Internal Medicine } \\
\text { (1) } \\
\text { Child Neurology } \\
\text { (1) } \\
\text { Neonatalogy (1) } \\
\text { Medical Microbiol- } \\
\text { ogy (1) } \\
\text { Leprosy Project (1) } \\
\text { Malaria Project (1) } \\
\text { Rotation medical } \\
\text { care (5) } \\
\text { Orientation medical } \\
\text { care (3) }\end{array}$ \\
\hline
\end{tabular}




\section{Instruments}

The interview scheme was based on the authors' experience and prior work. ${ }^{15}$ Sensitising concepts served as starting points for interview topics. ${ }^{14,16}$ The following topics were discussed in the interviews: previous experience abroad, study results, motivational aspects of the internship, structure of internship, positive and negative learning experiences. Apart from direct questions about learning experiences, the interviewer specifically inquired about positive and negative learning experiences, using the critical incidents technique. ${ }^{17,18}$ This technique involves asking interviewees to describe incidents (events and behaviour) rather than perceptions, which has the advantage that the resulting information is less pre-interpreted. ${ }^{7}$

The interviews were conducted by the principal author at Maastricht University between February and September 2002. Interviews lasted 1-2 hours including post-interview conversations. Students received a $€ 7.5$ film voucher for participation.

\section{Analysis}

The interviews were taperecorded and transcribed verbatim immediately after the interview. Transcripts were analysed using the computer software Atlas-ti (Version 4.1). Analysis involved line by line scrutiny of transcripts with keywords being assigned to text fragments. For each interview, categories and themes were identified, which were subsequently tested and refined in a cyclic process, involving repeated analysis of both previous and following interviews. This type of analysis resembles the open coding and axial coding phases of grounded theory. ${ }^{12,16}$

To enhance the 'trustworthiness' of the study, i.e. diminish subjectivity, several quality checks were performed. ${ }^{19}$ Ten interviews were independently coded by an undergraduate medical student and the principal author. One interview was independently coded by a research fellow who was a recent medical graduate, and by the principal author. In both procedures, the author and the co-analyst compared the codings and analysed their consistency. Disagreements were few and were resolved by consensus. Discussions about the research design between the principal author and the research fellow functioned as 'peer debriefing' as well. $^{19}$

After interview no. 21 no new information concerning the research question was found, indicating that saturation was reached. ${ }^{13}$ 


\section{Results}

\section{Description of students}

Seventeen students of the 24 interviewees had previous international experience: international medical internship(s) (10), parents living abroad (temporarily) (5) education abroad other than medicine (5) nuclear family members from other country (4) backpacking outside Europe (4) medical training abroad (1). The remaining students were six third-year students and one sixth-year student, who indicated that he wished to have a solid grounding in Dutch medicine before going abroad.

\section{Description of internships}

Most of the orientation electives consisted of three two-week periods in different hospital departments and/or community settings. Some of the third-year students spent the orientation electives on local regular clerkships. This is early given that at Maastricht regular clerkship does not start until the end of fourth year. Students were allowed to perform tasks of varying degrees of complexity at different internship sites. A third year female student reported performing advanced skills during a gynaecology orientation elective in Sweden (no. 10):

"During the actual Caesarean I was allowed to stand close by and as soon as the child was out I was allowed to do the rest, closing the womb ..."

Another third-year female student reported a less advanced skill on a gynaecology orientation elective in Malaysia (no. 5):

". . and I was allowed to remove the placenta from the vagina ..."

The regular and elective clerkships were limited to one discipline with rotations in different hospital departments and community sites. If educational facilities were available at internship sites students participated in regular local attachments. There was not much difference between students in the advancedness of tasks performed during these clerkships.

Research internships varied widely in structure and in tasks. Students remained at the internship site for the full three months in most research projects. One student spent only a few weeks on the spot to gather data and finished the research report at home. Two students had not finished their report almost one year later. Some students were required to perform the full empirical cycle; others performed only isolated parts of a larger study.

Eleven students went abroad in a group of fellow students. They spent both work and leisure time together. Six students did the internship alone and spent 
their free time with other Dutch students. Seven students had no contacts at all with other Dutch students (table 2).

Table 2 Overview of various types of internships and prototypic examples of how they were structured.

\begin{tabular}{|c|c|c|}
\hline $\begin{array}{l}\text { Orientation elective } \\
\text { (6 weeks) }\end{array}$ & $\begin{array}{l}\text { Research internship } \\
\text { (12 weeks) }\end{array}$ & $\begin{array}{l}\text { Elective/ regular clerkship } \\
\text { (6 weeks) }\end{array}$ \\
\hline $\begin{array}{l}\text { Biweekly tutorials; rest of the } \\
\text { week attached to a specialist } \\
\text { in child neurology or self } \\
\text { study (Finland). }\end{array}$ & $\begin{array}{l}6 \text { weeks gathering data from } \\
\text { patient files in a rural hospital; } \\
6 \text { weeks analyzing data and } \\
\text { writing report on site (Egypt). }\end{array}$ & $\begin{array}{l}\text { Working as a rural GP super- } \\
\text { vised by local students (Mex- } \\
\text { ico). }\end{array}$ \\
\hline $\begin{array}{l}\text { Two weeks observing in } \\
\text { hospital gynaecology de- } \\
\text { partment; two weeks attend- } \\
\text { ing community visits; two } \\
\text { weeks observing in hospital } \\
\text { child health department. } \\
\text { Performing minor tasks } \\
\text { (Malaysia). }\end{array}$ & $\begin{array}{l}6 \text { weeks gathering clinical data } \\
\text { from pregnant women in a big } \\
\text { city hospital department; } 6 \\
\text { weeks collecting question- } \\
\text { naires and entering data into } \\
\text { computer and writing report on } \\
\text { site (New York). }\end{array}$ & $\begin{array}{l}\text { Three-week regular clerkship } \\
\text { rotations in two hospital } \\
\text { departments (Bahrain). }\end{array}$ \\
\hline $\begin{array}{l}\text { Two weeks of self study; two } \\
\text { weeks of local clerkships in } \\
\text { the orthopaedics department; } \\
\text { two weeks of observing } \\
\text { orthopaedic surgeons in } \\
\text { operating theatre and doing } \\
\text { clinical work (Israel). }\end{array}$ & $\begin{array}{l}12 \text { weeks conducting animal } \\
\text { experiment in laboratory of a } \\
\text { big city hospital; writing report } \\
\text { back home in Maastricht } \\
\text { (Canada). }\end{array}$ & \\
\hline $\begin{array}{l}\text { Three two-week rotations in } \\
\text { three different hospitals, in } \\
\text { rural areas and in a big city } \\
\text { (Ecuador). }\end{array}$ & $\begin{array}{l}4 \text { weeks gathering clinical data } \\
\text { from patients in the capital of a } \\
\text { developing country; } 6 \text { weeks } \\
\text { data analysis and writing } \\
\text { report back home (Nairobi). }\end{array}$ & \\
\hline
\end{tabular}

\section{Learning outcomes}

The analysis of the interviews showed that learning outcomes could be clustered into six domains: medical knowledge, skills, international health care organisation, international medical education, society and culture, and personal growth. Within these domains various dimensions could be distinguished (table 3). Learning outcomes were also categorised according to how they were achieved: by observation (watching procedures and events), by doing (performing actions and procedures), or by experiencing (an 'inner process') (table 3 ). The domains will be illustrated by excerpts from interviews. 
Table 3 Learning outcomes from international internships; numbers indicate how many times an outcome is mentioned in different interviews $(\mathrm{n}=24)$.

\begin{tabular}{|c|c|c|c|c|}
\hline \multirow[t]{2}{*}{ Domains } & \multirow{2}{*}{ Dimensions } & \multicolumn{3}{|c|}{ Learning experience by: } \\
\hline & & Observation & Doing & Experience \\
\hline $\begin{array}{l}\text { Medical } \\
\text { knowledge }\end{array}$ & Syndromes $\backslash$ Treatments & 15 & 1 & \\
\hline Skills & $\begin{array}{l}\text { Medical } \\
\text { Technical } \\
\text { Scientific } \\
\text { Teaching } \\
\text { Reflection on cultural differences } \\
\text { Consultation } \\
\text { Sensitivity for context of patients } \\
\text { Sensitivity for culture-bound } \\
\text { presentation of symptoms } \\
\text { Intercultural communication } \\
\text { Language (medical English or } \\
\text { other language) } \\
\text { Presentation in foreign language }\end{array}$ & $\begin{array}{l}3 \\
1\end{array}$ & $\begin{array}{l}9 \\
4 \\
6 \\
1 \\
7 \\
3\end{array}$ & \\
\hline $\begin{array}{l}\text { International } \\
\text { health care }\end{array}$ & $\begin{array}{l}\text { Healthcare organisation } \\
\text { Hospital culture } \\
\text { Indigenous medicine } \\
\text { Indigenous sick role } \\
\text { Different diagnostics (due to lack } \\
\text { of diagnostic means) } \\
\text { Vision on international develop- } \\
\text { ment aid }\end{array}$ & $\begin{array}{c}15 \\
14 \\
5 \\
9 \\
5 \\
\end{array}$ & $\begin{array}{l}3 \\
3 \\
1\end{array}$ & \\
\hline $\begin{array}{l}\text { International } \\
\text { medical educa- } \\
\text { tion } \\
\text { Society and }\end{array}$ & $\begin{array}{l}\text { Educational organisation } \\
\text { Educational methods } \\
\text { Culture } \backslash \text { Religion }\end{array}$ & 22 & $\begin{array}{l}2 \\
2\end{array}$ & 5 \\
\hline Personal growth & $\begin{array}{l}\text { Self-knowledge } \\
\text { Self-confidence in functioning in } \\
\text { medical profession (self- } \\
\text { efficacy) } \\
\text { Self management } \\
\text { Widening of one's horizon } \\
\text { Clarity about preferences for } \\
\text { specialisation }\end{array}$ & 6 & 12 & $\begin{array}{l}9 \\
5\end{array}$ \\
\hline
\end{tabular}


Interviewees also mentioned knowledge acquisition from books and the Internet. One student mentioned that he had to study and was tested on his knowledge of a book written by his external supervisor (no. 1). It seemed superfluous to add this as an extra dimension to the outcomes table.

In the domain 'medical knowledge' learning mainly occurred by observation, mostly of patients with specific syndromes (e.g. infectious diseases) and procedures (e.g. operations). An example of learning both by 'observation' and 'doing' was provided by a third-year female student on an orientation internship in Sweden (no. 10):

"I learned a lot about gynaecology. This year we had our first real gynaecology subjects. I found I had a lot of prior knowledge; I had gained knowledge partly without noticing it, just by seeing a lot and by being allowed to do a lot. The best part was of course, that I was allowed to do things, because when you do things yourself, it is easy to remember them."

In the domain of 'skills', learning largely occurred by 'observation' and by 'doing' as well. This is illustrated by the experiences of a third-year male student in Israel (no. 4):

"And I was allowed to actually perform a few operations. . . For instance hip operations ... if elderly people fall, they often fracture the top of an upper leg. A screw is then inserted to stabilise it, so that it can heal better. It is an operation they do daily, so I saw it many times. I built it up slowly, starting by just observing and doing more and more myself. Until finally I performed the whole procedure and was more or less in charge of the operation."

In the domain 'international health care' learning outcomes on the dimension 'indigenous sick-role' were mostly in the category 'observation'. Learning by 'doing' occurred, however, when students fell ill and were forced to play the culturally acceptable sick role. An example of learning by 'observation' was given by a male student who went to the Philippines (no. 3):

"If people want drugs they largely have to pay for them out of their own pocket. That's why education is so important. You have to encourage people to spend money on it, also for their children. . . . In the Netherlands everybody knows, if there's something wrong, you go to your GP. But over there, there is no GP. If something is wrong, people stay at home and they don't go to see a doctor because they think it's just another fact of life that it hurts when they urinate."

In the domain of 'international medical education', learning outcomes on the dimension 'educational methods' mostly occurred by experience and sometimes by doing. Students 'experienced' international educational methods on clerkship 
rotations or when they attended lectures. Students learned by 'doing' when they participated in the local educational and examination system. This applied for students on a regular clerkship. A male student gave an example from his experiences in Bahrain (no. 19):

"Rounds were a learning moment. Together with a group of residents and two specialists cases were discussed at the bedside. . . It was much more used as an educational opportunity. . . . There was active questioning, like, why are we doing this? And if such a problem should arise, then what would you do: an ultrasound or a scan? These kinds of questions. It was very good. It should be done in the Netherlands as well, although it takes much more manpower of course."

In the domain of 'society and culture' the learning outcomes on the dimension 'culture' were predominantly achieved by 'observation'. In some cases students had to actually 'perform' culturally prescribed roles. In Islam-dominated cultures female students had to adjust themselves to the culturally prescribed female role. An illustration is given by a fifth year female student in rural Egypt (no. 6):

"I mean, a woman must present herself as slightly timid, and I'm not very good at that. Certainly in the way you dress, you have to cover a lot. Especially men insist on that. . . . Sometimes you're corrected for using too many words or for the jokes you make."

In the domain of 'personal growth' learning took place by 'observation', 'doing' and 'experiencing'. The following example illustrates learning by 'experiencing' on the dimension 'self-knowledge' by a fourth-year female student in New York (no. 9). She did a internship in a New York hospital where the bodies of victims of the terrorist attack on September 11th, 2001, were gathered:

"And then the panic of bomb alerts. My room was close to the Empire State Building. I was called out of bed for the first time on Wednesday night: bomb alert, we have to go! You're under pressure and only when I was back home, did I notice the release of tension. But I wasn't afraid. I was very moved by what had happened to all these people. Yes, I found that out too, that I'm able to stay cool. I found myself to be a down to earth Dutch girl, in that sort of situation."

Another example of learning by 'experiencing', this time in the domain of 'personal growth' on the dimension 'self-confidence in functioning in the medical profession' was provided by a sixth-year female student who went to Aruba (no. 20):

"You had to examine a patient with stomach pain. . . At that moment you are there and you have to make the decisions. You go back to the theory 
and you think: I learned it that way, and it must be that. Then you gain confidence. That's the positive side, you think: I can do this!"

Table 4 Overview of problems encountered by students during an international internship.

\begin{tabular}{|c|c|}
\hline & Problems \\
\hline Cultural & $\begin{array}{l}\text { Culture shock } \\
\text { Communication problems } \\
\text { Assault tharassment }\end{array}$ \\
\hline Political & $\begin{array}{l}11 \text { September } 2001 \text {, New York } \\
\text { Shootout with royal family in Nepal } \\
\text { Medical doctors on strike in Ecuador }\end{array}$ \\
\hline Programme and supervision & $\begin{array}{l}\text { Severe sickness of external supervisor } \\
\text { Delegation of external supervision to others } \\
\text { Organisational weaknesses in the programme } \\
\text { Disappointing changes in the programme }\end{array}$ \\
\hline Sickness & $\begin{array}{l}\text { Severe physical disease of student } \\
\text { Severe psychological disease of student }\end{array}$ \\
\hline Personal & $\begin{array}{l}\text { Moral dilemmas in relation to treating patients } \\
\text { Being assertive in asking for attention or supervision } \\
\text { Conflict with fellow students } \\
\text { Loneliness }\end{array}$ \\
\hline
\end{tabular}

\section{Problems}

Students reported all sorts of problems, which could be clustered into five domains: culture, politics, programme and supervision, sickness of the student and personal problems (table 4). Coping style turned out to play an important role in dealing with problems. This will be illustrated by examples involving unavailable supervisors.

The supervisor of a fifth-year student on a research internship in Canada was frequently absent (no. 8). The student was swamped with work, at one time spending 21 days in a row in the laboratory where she conducted an animal experiment and managed a multicultural team of assistants. She was under tremendous pressure. Instead of bringing this to her supervisor's attention, she worked it off by exercising and contacting her boyfriend back home. During the 
interview (almost one year after the internship), she cried when she was telling about her experiences. Her coping style can be characterised as 'avoiding'.

Another fifth-year student on a research internship in Malawi was confronted with severe sickness of his supervisor (no. 15). As a result, he had to design the questionnaire and organise the fieldwork mainly by himself. He tried to find as much support as he could, but even his supervisor in the Netherlands turned out to be hard to contact. On the one hand he experienced his situation as having to reinvent the wheel without much help from his supervisors. On the other hand he experienced it as a powerful learning environment. By handling the situation in this way he was using an 'active' coping style.

There was not much difference in the quantity of learning outcomes achieved by these two students, apart from the extra dose of self-knowledge mentioned by the student with the 'avoiding' coping style.

Despite these problems, the overall evaluation of the internship was (very) positive for all but two of the students. The negative evaluations did not concern the internships that were selected because of suspected low learning value. The reasons for a less positive evaluation were inefficiency of the organisation of the programme and inadequate supervision.

\section{Discussion}

The aim of the study was to explore holistically and inductively the outcomes of student mobility. A weak point of this study is that the findings are based on students' self-reports only. Furthermore the limited level of analysis and sample size preclude any firm conclusions to be drawn on the basis of the findings. Quality control, however, was achieved through additional data analysis by a medical student and an independent medical researcher. ${ }^{14,19}$

With the exception of learning outcomes in the domain of 'international medical education', the results are consistent with findings from American studies. ${ }^{10,11}$ The absence of results on 'international medical education' in the American studies was probably due to the strong regulation of education at the foreign internship sites by the American medical school. The dimension 'selfconfidence in functioning in the medical profession' in the domain 'personal growth' appears to be related to the concept of 'self-efficacy'. 20,21

More than two thirds of the interviewees had prior international experience (i.e. personal and/or educational). In comparison, some $44 \%$ of the Maastricht University students of the clerkship year group 2000/2001, who went abroad for study purposes during their study, did so more than once. ${ }^{22}$ Something similar was found in a sample of American medical students going abroad for internships. ${ }^{10}$ The students were experienced international travellers. In a questionnaire survey on global influences on health and teaching issues at an English 
university among undergraduate medical students, women, students with experience in developing countries, and students who were members of political, voluntary or lobbying organisations were more likely to support teaching on these issues. ${ }^{3}$ Apparently, the international orientation of the students in our sample was not due to selection bias. On the contrary, students who went abroad for internships appeared to form a special, internationally oriented, group among undergraduate medical students.

Taking the limitations of this study into account, we conclude that international internships can affect the ability of doctors to meet the requirements posed by globalisation. For instance, for the domain of 'medical knowledge', students mentioned having observed very diverse syndromes and (indigenous) treatments. Students had also observed different cultures and religions. In the domains of 'international health care' and 'international medical education' students reported having observed international healthcare organisations, international hospital cultures and indigenous sick roles.

In addition, the international internships appear to meet generic objectives of medical education also. Students reported having observed and performed a variety of medical, technical, scientific and language skills. Generic objectives are also among the described learning outcomes concerning personal growth dimensions.

The problems students mentioned may be assumed to bear some resemblance to problems students encounter on internships at home. Nevertheless, being in a strange environment, maybe without support from family and friends, is likely to add an extra dimension to coping with problems. Coping style was found to be important in dealing adequately with problems, although it did not appear to affect the learning outcomes. Considering that some students were allowed to perform very advanced tasks and had to deal with potentially dangerous and difficult circumstances, it may be advisable to prepare students by paying attention to their coping styles.

What students learned appeared to be unrelated to their year of study, type of internship, or the country they visited. Presumably, the quantity and nature of learning experiences depend on other factors. For reasons of efficiency and effectiveness it will be interesting to investigate what factors may be involved. 


\section{References}

1. Unwin E, Alberti G, Aspray T, Edwards R, Mbanya J, Sobngwi, Mugusi F, Rashid S, Setel P, Whiting D. Economic globalisation and its effect on health. British Medical Journal 1998;316:1401-2.

2. Bateman C, Baker T, Hoornenborg E, Ericsson U. Bringing global issues to medical teaching. Lancet 2001;358:1539-42.

3. Edwards R, Rowson M, Piachaud J. Teaching international health issues to medical students. Medical Education 2001;35:807-8.

4. Eckhert NL. The global pipeline: too narrow, too wide or just right? Medical Education 2002;36:606-13.

5. De Wit JWM. Internationalisation of higher education in the United States of America and Europe. Amsterdam: PhD Thesis, 2001.

6. Knight J. Monitoring the quality and progress of internationalisation. Journal of Studies in International Education 2001;5:228-43.

7. Van der Wende MC. Internationalising the Curriculum in Dutch Higher Education: an International Comparative Perspective. Utrecht: PhD Thesis, 1996.

8. Teichler U. Changes of ERASMUS under the umbrella of SOCRATES. Journal of Studies in International Education 2001;5:201-227.

9. Majoor GD, Niemantsverdriet S, Groen MM, ten Haven GEA, Hulstaert CE, Nijenhuis M, Vorstenbosch MATM, Willemstein SC. Internationalisering van het medisch onderwijs, de stand van zaken. (Internationalization of medical education: state of the art.) Tijdschrift Medisch Onderwijs (Dutch Journal of Medical Education) 2003;22:18-27.

10. Godkin MA, Savageau JA. The effect of a global multiculturalism track on cultural competence of preclinical medical students. Family Medicine 2001;33:178-86.

11. Thompson MJ, Huntington MK, Hunt DD, Pinsky LE, Brodie JJ. Educational effects of international health electives on US and Canadian medical students and residents: A literature review. Academic Medicine 2003;78:342-7.

12. Strauss AL. Qualitative Analysis for Social Scientists. Cambridge: Cambridge University Press, 1987.

13. Charmaz K. Grounded Theory: objectivist and constructivist methods In: Denzin NK, Lincoln YS. (Eds) Handbook of Qualitative Research. Thousand Oaks, CA: Sage Publications; 2000.

14. Patton M. Qualitative Evaluation and Research Methods. Newbury Park, CA: Sage Publications, 1990.

15. Workgroup Internationalisation Faculty of Medicine. Internal Report. Maastricht University; 1997.

16. Wester F. Strategieën voor kwalitatief onderzoek. (Strategies for qualitative inquiry.) Bussum: Coutinho, 1995.

17. Flanagan JC. The critical incident technique. Psychological Bulletin 1954;51:327-58.

18. Wagenaar A, Boshuizen HPA, Scherpbier AJJA, van der Vleuten CPM. Reflection and supervision in learning in internships: a critical incident study among students of different disciplines. Advances in Health Sciences Education (Accepted 2003).

19. Lincoln YS, Guba G. Naturalistic Inquiry. Newbury Park: Sage, 1985.

20. Bandura A. Self-efficacy mechanism in human agency. American Psychology 1982;37;122-47.

21. Eraut M, Alderton J, Cole G, Senker P. Development of Knowledge and Skills in Employment. Brighton: University of Sussex, Institute of Education, 1998.

22. Aarts M. Internal Report. Maastricht University: Institute for Medical Education, 2002. 



\title{
Chapter 4
}

\section{Students' Perceptions of Their Learning Processes ${ }^{1}$}

\begin{abstract}
Objective: To explore the learning process of undergraduate medical students doing international internships.

Methods: Semi-structured in-depth interviews were conducted with 24 undergraduate medical students of Maastricht University Medical School, the Netherlands. The 24 subjects were selected by purposeful sampling. Research methods resemble Grounded Theory method. Although the data were initially gathered for an earlier study, the richness of the data enabled renewed scrutiny of the data.

Results: The data yielded the following categories concerning the description of the learning processes: motivation, preparation, internal supervisor, external supervisor, assessment, and positive and negative incidents. The majority of supervisors' influences on the learning process were facilitative or negligible. Socio-cultural differences between students and supervisors sometimes appeared to blur productive learning.

Discussion: A greater part of the students seemed to learn by 'experiential learning', a smaller part of the students learned by 'active learning', and the learning of a very small minority of the students appeared to be 'guided'.

Conclusion: Although experiential learning seemed to be the dominant learning process, it is not clear whether this is also the most fruitful approach to learning. It could be argued that structuring learning outcomes by a more active learning process could be even more effective. To guide the learning process and learning outcomes, it might be advisable to develop guidelines for writing interna-
\end{abstract}

\footnotetext{
${ }^{1}$ This chapter has been published as: Niemantsverdriet S, van der Vleuten CPM, Majoor GD \& Scherpbier AJJA. An explorative study into learning on international internships; experiential learning processes dominate. Medical Education 2005;39:1236-1242.
} 
tional internship reports. Supervision of these reports should be more coordinated to prevent arbitrariness and to scaffold active learning.

\section{Introduction}

In an earlier study we outlined why we thought the learning outcomes of international internships remain to be examined. ${ }^{1}$ In this earlier study we used a holistic and inductive approach to explore what undergraduate medical students learned from internships abroad. It resulted in an elaborate overview of learning outcomes. What students learned appeared to be unrelated to their year of study, type of internship or the country they visited. Some students performed very advanced tasks, whereas other students had very limited learning experiences. The findings led to the question: which factors affect the quantity and nature of learning outcomes in international internships? On the basis of earlier findings regarding the learning environment, we hypothesized that factors related to the learning process might help clarify this issue. ${ }^{1}$ Therefore we now explored the nature of the learning process that takes place when undergraduate medical students do an international internship.

\section{Methods}

\section{Method}

In an earlier study, students' perceptions were explored using semi-structured in-depth interviews. ${ }^{1}$ Data were collected and analysed by the constant comparative method, involving a cyclic, iterative process of 'data collection - analysisreflection'. This process is characterised by analytical interpretation of the data, which focuses further data collection, thereby enabling refinement of the theoretical analyses. ${ }^{2,3}$ Initially these data were gathered focussed on 'what' learning outcomes students achieved. The richness of the data enabled renewed scrutiny of the data, this time focussing on the nature of students' learning processes.

\section{Setting and subjects}

The study was performed at Maastricht Medical School. Students are offered an orientation elective in year 3, which may be spent abroad. In years 4-6 students can go abroad for a regular clerkship, an elective clerkship or research training. In this study, all these opportunities for gaining international experience are referred to as international internships. ${ }^{1}$

In the academic year 2000/2001, out of a total of 1325 undergraduate medical students, 243 enrolled in an international internship. ${ }^{4}$ A total sample of 24 stu- 
dents was selected, using purposeful and theoretical sampling (the researcher decides what data to collect next on analytic grounds in order to find varying dimensions). ${ }^{2}$ More detailed information about the sample has been presented in an earlier publication. ${ }^{1}$

\section{Instrument}

The interview scheme was based on the authors' experience and prior work at Maastricht Medical School. ${ }^{6}$ Sensitising concepts (background ideas that inform the overall research problem) served as triggers for interview topics. ${ }^{5,7}$ Apart from direct questions about learning experiences, the students were asked to describe two learning experiences, i.e. the most positive and the most negative one. This was done using the critical incidents technique, involving asking interviewees to describe incidents (events and behaviour) rather than perceptions, which has the advantage that the resulting information is less pre-interpreted. ${ }^{8}$ The value of these incidents for the exploration of the learning process lies (also) in the strategies that the students did or did not use to achieve the learning outcomes of these incidents. As such they don't need to be uniform learning experiences. More detailed information about the instrument and the way it was used, has been presented in an earlier publication. ${ }^{1}$

\section{Analysis}

The interviews were tape-recorded and transcribed verbatim in our earlier studie. ${ }^{1}$ For this study, transcripts were analysed using the computer software Atlas-ti (Version 4.1). Initial analysis involved line by line scrutiny of the transcripts with keywords being assigned to text fragments. This resulted in the identification of categories. If subsequent interviews yielded new categories, these were tested on the previous interviews, which, in turn, might lead to modification of the categories. In this way categories evolved in an iterative process of addition and adaptation. The resulting categories were compared to insights from the literature, to add scope and go beyond local meanings of the data. The analytic approach used resembles the 'open coding' and 'axial coding' phases of grounded theory. ${ }^{2,3,7}$

\section{Results}

The analysis resulted in six categories which are described in the following paragraphs. 


\section{Motivation}

Students gave several reasons for doing an international health elective. Nineteen students said they wanted to see the daily practice and organisation of healthcare in another country. Other students had been made enthusiastic by fellow students' internship stories (10); expected more active involvement in patient care than in internships at home (5); wanted to discover how they would cope without the support from family and friends (4); liked to finish their study programme abroad and combine this experience with a holiday (4); or wanted to find out whether specialisation in Tropical Medicine would be the right choice for them (3).

The choice of a site or country depended on the specialty or study topic offered at particular sites (13). Another consideration was the chance to improve foreign language skills (7), with most students wanting to practise English and some students Spanish. Some students considered the developmental stage of the country (3).

\section{Preparation}

Most students thought it neither possible nor advisable to draw up a detailed learning plan in advance. Two students, who did a regular clerkship abroad, claimed that preparing for an international clerkship was just as difficult as for a clerkship at home, because you never knew exactly what to expect.

Two students prepared very thoroughly. They made clear arrangements with their internal and external supervisor about the internship programme, the goals, the requirements for the internship report and the supervisors' role. They also learned about the local language and one student read the relevant medical literature very thoroughly.

Twenty-two students did less preparation, although some wrote a research protocol; contacted the external supervisor to make programme arrangements; did some initial reading and language preparation and spoke to students who had done a internship at the same site. In many cases, however, arrangements had to be finalised or altered upon arrival at the internship site.

\section{Internal supervisor (home university)}

Most students (17) met their internal supervisor one to three times, and only four students had many more contacts. Three students said that there had not been any personal contact with their supervisor. Some students (10) kept in touch with the supervisor by e-mail during the internship. Before the internship, students had to obtain their internal supervisor's approval of the internship and some supervisors gave information about the country of the internship and/or discussed a research proposal. After the internship, students had to submit a report to the internal supervisor. Three students expressed dissatisfaction with 
the frequency of the contacts or the sparse instructions for the report. The majority of the students (15) did not seem to mind the lack of intensive contact.

\section{External supervisor (abroad)}

Fifteen students were satisfied with their external supervisor, four had mixed feelings and five were dissatisfied. Reasons for satisfaction were that the supervisor had been kind, helpful, competent, willing to answer questions and give advice and had organised a good programme for the student. Other reasons were help with problems, for instance when students had been robbed, and supervisors inviting students to spend leisure time with them.

Seventeen students reported that their external supervisor delegated most of the supervisory tasks to others, such as clinical specialists, residents, students, health care workers or academic staff. Delegation of supervision was highly appreciated by the students if it occurred at their own request when they wanted to see or learn particular things.

Interviewees (5) gave as reasons for dissatisfaction: poorly organised, delegated supervision, supervisors who took no responsibility for the student or applied very strict rules as to what the student was allowed to do or not. The four students with mixed feelings about delegated supervision felt they could have learned more with proper supervision.

Cultural differences between the external supervisor and the student were also mentioned in the interviews (5). These differences could cause communication problems, such as the supervisor whose cultural code required saying 'yes' to all requests (but not actually keeping these promises) or the supervisor who was always late.

\section{Assessment}

The external supervisor had to fill out a standard evaluation form about the student at the end of the internship. Students differed in their experiences with this assessment. At the extreme positive end, two students saw the assessment as a useful feedback moment. Whenever the need arose different external supervisors had been consulted about the assessment. At the extreme negative end, two students perceived the assessment as not useful, e.g. because the external supervisor had hardly seen the student and was therefore not able to give a considered assessment. One student interpreted his surprisingly positive assessment as a way for the external supervisor to strengthen the relationship with his home university.

All students had submitted a report to their internal supervisor. Instructions on how to write the report had ranged from hardly any to the requirement to produce a brief study design before the internship. Students spent from one afternoon to several weeks or months on the report. The internal supervisors' as- 
sessment varied from just signing the assessment form to a thorough discussion of the report with suggestions for further reading and adjustments.

Students who did a regular clerkship abroad took the same examination as their peers who did the clerkship at home.

\section{Positive and negative incidents}

During the interviews students were asked to describe the most positive and the most negative incident related to their learning experiences as trainees (See table 1). 'Performing clinical skills was considered a very positive experience, which was enjoyable or increased students' sense of self efficacy. 'Insight into society and culture' was mentioned as an experience that had broadened the student's horizon. 'Enhancement of medical knowledge' was related to learning about syndromes and treatments. The 'positive experience with expert supervision' was related to learning about specialised topics, e.g. statistics.

'Confrontation with corruption and slack behaviour towards and within healthcare' was mentioned as a negative experience. Students reported that this experience had made them aware of the difficulties within medicine in developing countries. Learning experiences from 'confrontation with severe poverty, discrimination, and being robbed' were reported as enhancing self management and personal growth. Negative incidents with 'unwilling and/or incompetent supervisors' gave rise to negative learning experiences related to unfulfilled learning potential. It was striking, however, that negative incidents could constitute a positive learning experience, such as an increased sense of self-efficacy due to observing an incompetent supervisor and learning about intercultural communication skills the hard way.

The overall evaluation of the internship was (very) positive for all but two of the students, who were dissatisfied with inefficient programme organisation and inadequate supervision. 
Table 1 Positive and negative incidents ranked by number of times mentioned in separate interviews ( $\mathrm{n}=24,1$ missing).

\begin{tabular}{|c|c|c|c|}
\hline Positive incident & $\begin{array}{l}\text { Num- } \\
\text { ber }\end{array}$ & Negative incident & $\begin{array}{c}\text { Num- } \\
\text { ber }\end{array}$ \\
\hline Medical skills practicing & $9 x$ & $\begin{array}{l}\text { Confrontation with corruption and } \\
\text { slack behaviour towards and within } \\
\text { healthcare }\end{array}$ & $6 x$ \\
\hline Insight in society and culture & $6 x$ & $\begin{array}{l}\text { Confrontation with severe poverty, } \\
\text { discrimination, robbery }\end{array}$ & $6 x$ \\
\hline Medical knowledge enhancement & $3 x$ & $\begin{array}{l}\text { Unwilling and/or incompetent } \\
\text { external supervisor }\end{array}$ & $6 x$ \\
\hline $\begin{array}{l}\text { Positive experience with expert } \\
\text { supervision }\end{array}$ & $2 x$ & $\begin{array}{l}\text { Confrontation with limits of medi- } \\
\text { cine by disease and death in young } \\
\text { children }\end{array}$ & $3 x$ \\
\hline $\begin{array}{l}\text { International healthcare organisation; } \\
\text { got acquainted with different hospi- } \\
\text { tal culture }\end{array}$ & $1 \mathrm{x}$ & $\begin{array}{l}\text { Intercultural communication skills } \\
\text { development }\end{array}$ & $2 \mathrm{x}$ \\
\hline $\begin{array}{l}\text { International medical education; } \\
\text { getting acquainted with a more } \\
\text { powerful organization of medical } \\
\text { education }\end{array}$ & $1 \mathrm{x}$ & Loneliness during leisure time & $1 \mathrm{x}$ \\
\hline $\begin{array}{l}\text { Clarity about specialisation prefer- } \\
\text { ence for Tropical Medicine }\end{array}$ & $1 \mathrm{x}$ & & \\
\hline Total & $23^{1}$ & Total & $24^{1}$ \\
\hline
\end{tabular}

${ }^{1}$ One student could not mention either a most positive or a most negative incident; one student could not distinguish between two most negative incidents 


\section{Discussion}

\section{Learning theory}

To add scope and go beyond local meanings of the data the categories that emerged during analyses were compared to insights from the literature. The current educational insights described under 'new learning' were considered suitable. ${ }^{9,} 10$ 'New learning' distinguishes three types of learning processes according to the nature of guidance: namely guided learning, experiential learning and action learning (also called self-directed or active learning). Three types of learning functions are distinguished: preparatory, executive and closing functions. In 'guided learning', the teacher performs most of the learning functions, and in 'action learning' the student does so. In 'experiential learning', learning is a side effect of activities undertaken. ${ }^{9,} 10$ (Even when students are complete action learners, supervisors still play a role, e.g. as coaches, experts, consultants, role-models.)

The learning process of most of the students appears to match 'experiential learning'. Students' learning plans were rather vague (preparatory function) and they decided how, when and where to learn at the internship site (executive function). The closing of the learning experience was very diverse and subject to students' personal creativity (closing function). 'Experiential learning' seems to be represented by the positive incidents of 'gaining insight into society and culture' and 'medical knowledge enhancement', and by negative incidents like 'intercultural communication skills development' and 'confrontation with the limits of medicine'. Neither these incidents nor the ensuing learning experiences were planned or guided. They simply occurred in the course of the internship.

The learning process of a minority of the students seemed to represent 'action learning', like the two students who planned very carefully, executed their plans as arranged and closed the internship in the same self-organised way. Other instances of 'action learning' were the students who planned to be 'more involved in patient care' and actually performed more clinical skills. Another instance is the student who mentioned 'clarity about specialisation preference' regarding Tropical Medicine. Finally, action learning was exemplified by the students who were highly satisfied with their supervisor because he or she arranged programme activities on request.

Some students seemed to lack the skills for 'action learning', like the students with mixed feelings who felt they could have learned much more with proper supervision. Possibly, these students lacked the skills to design their own learning environment. Skills for carrying out 'action learning' are not evenly distributed across students but they can be encouraged and fostered by supervisors. ${ }^{10}$ 
Guided learning seemed to occur in regular international clerkships concluded with the same assessment (closing function) as clerkships at home.

\section{Learning and motivation in context}

Clearly, the learning process in an international internship does not occur in a socio-cultural vacuum. An interesting perspective on learning and motivation in context was found by Volet. ${ }^{11}$ Given their social character; contexts should be conceived as dynamic communities in need of individual reciprocal understanding. Congruence at the experiential interface enables engagement in learning and productive learning. When students move across different educational settings, a mismatch in intersubjective perceptions and consequent lack of congruence between students and teachers becomes more noticeable at the experiential interface. The prevailing norms and expectations in a particular context are often tacit rather than explicit, which is experienced by students on entering university or by persons starting a new job. When students move to another learning context, the transfer may give rise to different subjective experiences, like feelings of ambivalence, perceived difficulties and incongruence. ${ }^{11}$

This mismatch seems applicable to the students who were dissatisfied with or had mixed feelings about their external supervisor, for example the student whose supervisor said 'yes', but did 'no' in response to requests, the student who mistrusted his positive assessment and the student whose supervisor was always late. These students did not experience congruence between their personal expectations and the socio-culturally determined behaviours of their supervisors and thus were unable to (fully) engage in productive learning. (Insight may help to solve mismatches, e.g. being aware that 'saying no to a request' is regarded highly impolite in some cultures.)

\section{Conclusion}

The aim of this study was to explore the nature of learning processes of undergraduate medical students doing international internships. It appeared that most of the students learning processes could be categorised as experiential learning." ${ }^{10}$ A minority of the students seemed to display action learning (self-directed learning or active learning). ${ }^{9,10}$ Aspects of guided learning seemed to occur in the international regular clerkships. 9,10 The majority of internal supervisors' influences on how students learned in international internships was negligible. Most external supervisors predominantly facilitated students' learning. The results of this study do not elucidate whether experiential learning processes are characteristic for international internships or are inherent in students' learning behaviour in general. The remarks of the students who compared preparation for 
an international internship to that for a regular clerkship suggest a more stable pattern of students' learning behaviour irrespective of the learning site.

Although experiential learning seemed to be the dominant learning process, it is not clear whether this is also the most fruitful approach to learning. Experiential learning in international internships appears to yield valuable learning outcomes, especially concerning globalisation, as indicated by the positive and negative incidents (insight in society and culture, international health care organisation, international medical education, confrontation with corruption and severe poverty, intercultural communication skills development). The success of students with more active learning behaviour in achieving their learning goals suggests that structuring learning outcomes by a more active learning process could be even more effective. Whether all students will be capable of designing their own learning environment is not clear though.

A weakness of this study is that the findings are based on self-reports. Furthermore, no firm or transferable conclusions can be drawn, due to the limited sample size and level of analysis (in Grounded Theory). Despite these limitations, we think the results justify the conclusion that students' learning processes can at least partly explain the nature and quantity of the learning outcomes. Further research could address the supervisor role, also to explore the possible sociocultural mismatch in the students' and supervisors' experiential interface. Future research is also recommended to test our findings in a representative sample of medical students.

A final issue concerns the diversity in supervision and assessment. It seems advisable to develop uniform guidelines for writing an internship report, since this may encourage the development of learning goals before the internship and reflection afterwards. In this way the report would guide both the learning process and the learning outcomes. Supervision of these reports should be more coordinated to prevent arbitrariness and to scaffold active learning.

\section{References}

1. Niemantsverdriet S, Majoor GD, Van der Vleuten CPM, Scherpbier AJJA. "I found myself to be a down-to-earth Dutch girl": A qualitative study into learning outcomes from internships abroad. Medical Education 2004;38:749-757.

2. Strauss AL. Qualitative Analysis for Social Scientists. Cambridge: Cambridge University Press; 1987.

3. Charmaz K. Grounded Theory: objectivist and constructivist methods In: Denzin NK, Lincoln YS. (Eds) Handbook of Qualitative Research. Thousand Oaks, CA: Sage Publications, 2000.

4. Majoor GD, Niemantsverdriet S, Groen MM, ten Haven GEA, Hulstaert CE, Nijenhuis M, Vorstenbosch MATM, Willemstein SC. Internationalisering van het medisch onderwijs, de stand van zaken. (Internationalization of medical education: state of the art.) Tijdschrift voor Medisch Onderwijs (Dutch Journal of Medical Education) 2003;22:18-27. 
5. Patton M. Qualitative Evaluation and Research Methods. Newbury Park, CA: Sage Publications, 1990.

6. Workgroup Internationalisation Faculty of Medicine. Internal Report. Maastricht University, 1997.

7. Wester F. Strategieën voor kwalitatief onderzoek. (Strategies for qualitative inquiry.) Bussum: Coutinho, 1995.

8. Flanagan JC. The critical incident technique. Psychological Bulletin 1954;51:327-58.

9. Simons PRJ, Van der Linden J, Duffy T. New learning: three ways to learn in a new balance. In: Simons PRJ, Van der Linden J, Duffy T. (Eds) New learning. Dordrecht: Kluwer Academic Publishers, 2000.

10. Van Hout-Wolters, B, Simons, PRJ, Volet SE. Active learning: self-directed learning and independent work. In: Simons PRJ, Van der Linden J, Duffy T. (Eds) New learning. Dordrecht: Kluwer Academic Publishers, 2000.

11. Volet SE. Learning and motivation in context: A multi-dimensional and multi-level cognitivesituative perspective. In: Volet SE, Järvelä S. (Eds) Motivation in learning contexts: Theoretical advances and methodological implications. London: Elsevier, 2001. 



\title{
Chapter 5
}

\section{Foreign Supervisors' Perceptions of Students' Learning Processes ${ }^{1}$}

\begin{abstract}
Objective: Semi-structured interviews were conducted with external supervisors of international electives undertaken by Dutch undergraduate students, in order to gain insight into student learning processes during these electives.

Design: The interviews served to triangulate information on these learning processes that was obtained from students' self-reports.

Results: The results of the case study reported in this paper were largely consistent with findings from prior studies of international electives in which we examined learning processes and socio-cultural differences: experiential learning processes appeared to dominate and socio-cultural differences occasionally seemed to blur productive learning, especially when the differences between the national cultures of host country and student home country were substantial.

Conclusion: It is recommended that students' experiential learning from international electives should be supplemented with 'guided' and 'self-directed' learning with a focus on the socio-cultural dimension.
\end{abstract}

\footnotetext{
${ }^{1}$ This chapter has been published as: Niemantsverdriet S, van der Vleuten CPM, Majoor GD \& Scherpbier AJJA. The learning processes of international students through the eyes of foreign supervisors. Medical Teacher 2006;28:e104-e111.
} 


\section{Introduction}

There is a growing demand for higher education from a global perspective. Within this framework, in 1999, 29 European countries, including the Netherlands, signed the Bologna declaration, in order to enhance transparency and international competitiveness of European higher education by the introduction of an undergraduate-graduate system. ${ }^{1}$ The global demand for higher education definitely applies to medical education as well. Eckhert $(2002)^{2}$ showed that the number and distribution of medical schools around the world were not well matched with the available numbers and distributions of physicians or with predicted population growth patterns.

Other important globalisation considerations are globalisation in the field of health care and the recognition of the worldwide effect of globalisation on population health and the delivery of health care. ${ }^{3-5}$ Clearly, there are many reasons why medical education should take account of internationalisation issues. ${ }^{2,6}$

Educational internationalisation can be achieved by internationalisation of the curriculum, by student mobility and by staff mobility. ${ }^{7,8}$ Internationalization of the curriculum may entail: inclusion of courses in the regular medical curriculum given in English; inclusion of topics on (imported) tropical diseases; inclusion of topics on international health care systems; facilities for foreign language learning; facilities for skills training for dealing with patients from different cultural backgrounds. ${ }^{9}$

Student mobility (i.e. students going abroad for part of their training) is the most common approach to internationalisation in education. ${ }^{10-12}$ Studies of what medical students learned from international health electives described various outcomes, including 'cultural sensitivity.' ${ }^{13,14}$ Cultural sensitivity may be defined as: being sensitive to the fact that patients possess diverse health values that may be based on culture, and that neither the health care provider's nor the patient's culture offers a preferred view. ${ }^{15}$ The limitations of these studies consisted of measuring instruments that were not properly validated or the limited number of variables considered. As Thompson et al. (2003) ${ }^{14}$ demonstrated, learning from international electives remained to be examined further.

Previously, we used a holistic and inductive approach to explore what undergraduate medical students learned from international electives. ${ }^{16} \mathrm{We}$ found that some students performed very advanced tasks, whereas others had very limited (hands-on) learning experiences. What students learned (an elaborate overview of learning outcomes) proved to be unrelated to year of study, type of elective or country visited. The observed differences between students in the nature and quantity of learning outcomes might be explained by experiences with unwilling and/or incompetent supervisors which some students mentioned in connection 
with unfulfilled learning potential. The results also suggested that students' learning processes might (at least partially) explain the differences. ${ }^{17}$

The nature of the learning processes reported by students were categorised using current educational insights described under 'New Learning' by Simons et al. (2000). ${ }^{18}$ 'New Learning' is characterised by a shift from traditional 'guided learning' towards more 'experiential' and 'self-directed learning' (in the educational literature, self-directed learning is also termed 'action' or 'active' learning.). Guided, experiential and self-directed learning processes differ in the way they are structured. In 'guided learning', the teacher structures most of the learning functions (preparatory, executive and closing functions), whereas in 'selfdirected learning', the student does so. In 'experiential learning', learning is an unstructured side effect of activities. ${ }^{19}$ Even with fully self-directed learning, supervisors may still play a role, e.g. as coaches, experts, consultants and role models.

In an earlier study ${ }^{17}$, 'experiential learning' emerged as the dominant learning process in international electives. The fact that in experiential learning, learning is an unstructured side effect of activities may (at least partly) explain the observed variety in the nature and quality of student learning outcomes. A minority of students seemed to use 'self-directed' learning styles, whereas 'guided learning processes' were confined to 'regular international clerkships'.

Another finding of this earlier study ${ }^{17}$ was that socio-cultural differences between students and supervisors sometimes appeared to interfere with productive learning, which was interpreted as socio-cultural mismatch in students' and supervisors' experiential interface. ${ }^{20}$

Our earlier studies explored undergraduate medical students' learning experiences from international electives by semi-structured in-depth interviews with students. ${ }^{16,17}$ Indications of the importance of the role of external supervisors, i.e. supervisors at the sites of international electives, in student learning prompted us to select external supervisors as an additional data source for triangulation. Our research questions were: (1) 'What is the nature of undergraduate medical students' learning processes from international electives?' and (2) 'Do socio-cultural differences influence these learning processes?' Although the first research question was explored in prior studies, we addressed it again, because of indications that nature and quantity of learning outcomes may (at least partly) be explained by the nature of the learning processes.

We added the second research question, because of indications that sociocultural differences between students and supervisors could hamper productive learning. ${ }^{17} \mathrm{We}$ derived a theoretical approach to this phenomenon from studies by Hofstede $(1986)^{21},(1996)^{22}$, who described four dimensions of differences between national cultures: individualism (as opposed to collectivism), power distance (less or more), avoidance of uncertainty (less or more) and masculinity (as opposed to femininity). Hofstede (1986), ${ }^{21}$ (1996), ${ }^{22}$ showed that these di- 
mensions can also be used to characterise the 'teacher-student' role pair. In a socalled 'collectivist society', for instance, students will expect to 'learn how to do things', whereas in an individualist society students will expect 'how to learn things'. As for power distance, in a so-called 'small power distance society', students are allowed to contradict or criticise their teachers, whereas in 'large power distance societies', this behaviour is unacceptable. Plotting country scores on the four dimensions on the indexes of two dimensions (e.g. a power distance by individualism-collectivism plot) showed that power distance and collectivism were disparate factors which nevertheless were jointly associated with national wealth. Consequently, the power distance by individualism-collectivism plot clearly separated third world countries from rich countries. In other plots (e.g. the masculinity-femininity by avoidance of uncertainty plot), countries were scattered differently and no association with national wealth was present.

\section{Methods}

\section{Method}

We used a case study design, because we were investigating a contemporary phenomenon (learning from international electives) within an authentic context without clear boundaries between phenomenon and context. ${ }^{23}$ A multiple case study, replication design was set up. Replication of the three cases was directed at the socio-cultural differences within the context of the elective sites:

- Case 1 encompassed a 'Rural and Remote Medicine' elective in Broken Hill, NSW Australia;

- Case 2 encompassed electives in urban areas in Sydney and Melbourne, Australia;

- Case 3 encompassed electives in non-Western countries, i.e. Kenya, Mexico, Philippines.

The Australian cases were chosen because the Netherlands and Australia were considered comparable as to 'national culture' dimensions (individualism, power distance, avoidance of uncertainty) as well as national wealth. ${ }^{21,22}$ Different Australian settings were selected to reflect the huge differences between urban and rural areas (outback). In the outback, students are far more likely to come into contact with indigenous (aboriginal) patients.

The countries of the non-Western case (Kenya, Mexico, Philippines) were chosen for the differences with the Netherlands in 'national culture' dimensions and national wealth, which was lower compared with that of the Netherlands. ${ }^{21}$ The research methods were semi-structured interviews and direct observations. 
Selection of cases

\section{Case 1 Australian outback}

The 'Rural and Remote Medicine' elective at the Department of Rural Health, University of Sydney at Broken Hill was selected because: 1) it was popular with undergraduate students of Maastricht University Medical School, the Netherlands (in the academic years 2001/2002; 2002/2003 and 2003/2004, it was undertaken by five, seven and four students, respectively); 2) students were able to learn about the health status and health needs of people living in remote rural areas and about cross-cultural perspectives in aboriginal health; 3) the language of the electives was English and 4) the coordinator of the 'Rural Attachments Programme' offered to assist in scheduling appointments for interviews with a range of supervisors, when she was contacted by e-mail by the principal author (table 1).

\section{Case 2 Australian urban areas}

External supervisors of electives in Australian urban areas were selected by two 'exchange student' coordinators of Maastricht University. The selection criterion was having supervised at least four Maastricht undergraduate medical students in recent years. Three supervisors (1x Sydney, 2x Melbourne) met this criterion and consented to being interviewed after e-mail invitations by the principal author (table 1).

\section{Case 3 Non-Western countries}

Five external supervisors of Dutch undergraduate medical students were selected from the participants in the 2003 'NetworkTUFH' (Towards Unity For Health) conference with the help of two 'exchange student' coordinators from Maastricht University. The selection criterion was the same as for case 2. The supervisors were invited by email to participate in an interview. The principal author interviewed four of them (2x Kenya, 1x Mexico, 1x Philippines) at the 2003 'NetworkTUFH' conference in Australia (table 1).

In all three cases we assumed that by selecting external supervisors in this way, we would select 'indigenous' supervisors. Although we did not directly check this out, there were no indications that we failed to select 'indigenous' external supervisors who were true representatives of the socio-cultural dimensions described by Hofstede $(1986)^{21},(1996)^{22}$. 
Table 1 Overview of characteristics of interviewees of the 3 Cases $(n=17)$.

\begin{tabular}{|c|c|c|c|}
\hline Job Title & Residence & Work organization & $\begin{array}{c}\text { Member } \\
\text { Check }\end{array}$ \\
\hline Case 1 Outback Australia & & & \\
\hline $\begin{array}{l}\text { Director of Emergency, } \\
\text { Medical Doctor }\end{array}$ & Broken Hill & Base Hospital & $\mathrm{X}$ \\
\hline $\begin{array}{l}\text { Director of Clinical Training, } \\
\text { Senior Lecturer and } \\
\text { Consultant Physician, } \\
\text { Haematology }\end{array}$ & Broken Hill & $\begin{array}{l}\text { University of Sydney / } \\
\text { Base Hospital }\end{array}$ & $\mathrm{X}$ \\
\hline $\begin{array}{l}\text { Nurse unit manager of } \\
\text { Emergency Department }\end{array}$ & Broken Hill & Base Hospital & - \\
\hline $\begin{array}{l}\text { Nurse Unit manager of } \\
\text { Medical Ward }\end{array}$ & Broken Hill & Base Hospital & - \\
\hline $\begin{array}{l}\text { Acting Nurse Unit Manager of } \\
\text { Orthopaedic Nursing }\end{array}$ & Broken Hill & Base Hospital & - \\
\hline $\begin{array}{l}\text { Associate clinical lecturer and } \\
\text { Senior Medical Officer RFDS }\end{array}$ & Broken Hill & $\begin{array}{c}\text { University of Sydney / Royal } \\
\text { Flying Doctor Service } \\
\text { (RFDS) }\end{array}$ & $\mathrm{X}$ \\
\hline $\begin{array}{l}\text { Rural Attachments Programme } \\
\text { Coordinator for Recruitment \& } \\
\text { Retention }\end{array}$ & Broken Hill & University of Sydney & $\mathrm{X}$ \\
\hline $\begin{array}{l}\text { Manager of Health Services of } \\
\text { PHC Aboriginal Health }\end{array}$ & Broken Hill & $\begin{array}{c}\text { Maari Ma } \\
\text { Aboriginal Health Corpora- } \\
\text { tion }\end{array}$ & $\mathrm{X}$ \\
\hline $\begin{array}{l}\text { Director of Nursing and } \\
\text { Executive Officer }\end{array}$ & Wilcannia & Wilcannia Health Service & $\mathrm{X}$ \\
\hline Registered Nurse & Wilcannia & Wilcannia Health Service & $\mathrm{X}$ \\
\hline
\end{tabular}


Table 1 -Continued- Overview of characteristics of interviewees of the 3 Cases $(n=17)$.

\begin{tabular}{|c|c|c|c|}
\hline Job Title & Residence & Work organization & $\begin{array}{c}\text { Member } \\
\text { Check }\end{array}$ \\
\hline \multicolumn{4}{|l|}{ Case 2 Australian Urban Area } \\
\hline $\begin{array}{l}\text { Medical Director of } \\
\text { Diving \& Hyperbaric Medicine }\end{array}$ & Sydney & $\begin{array}{c}\text { University of } \\
\text { New South Wales }\end{array}$ & - \\
\hline Prof of Neurology & Melbourne & University of Melbourne & $\mathrm{X}$ \\
\hline $\begin{array}{l}\text { Medical Director and } \\
\text { Prof of Paediatrics }\end{array}$ & Melbourne & Monash University & - \\
\hline \multicolumn{4}{|l|}{ Case 3 Non-Western countries } \\
\hline $\begin{array}{l}\text { Former Director of } \\
\text { Community Programme }\end{array}$ & $\begin{array}{l}\text { Monterrey/ } \\
\text { Mexico }\end{array}$ & $\begin{array}{l}\text { Universidad Autonoma } \\
\text { de Nuevo Leon }\end{array}$ & - \\
\hline $\begin{array}{l}\text { (past) Chair Dept. Preventive, } \\
\text { Family \& Community Medicine }\end{array}$ & $\begin{array}{l}\text { Manilla/ } \\
\text { Philippines }\end{array}$ & University of Santo Tomas & $X$ \\
\hline $\begin{array}{l}\text { Head of Dept. of Immunology } \\
\text { and } \\
\text { Senior Lecturer }\end{array}$ & $\begin{array}{l}\text { Eldoret/ } \\
\text { Kenya }\end{array}$ & Moi University & $\mathrm{X}$ \\
\hline Prof of Paediatrics & $\begin{array}{l}\text { Eldoret/ } \\
\text { Kenya }\end{array}$ & Moi University & $X$ \\
\hline
\end{tabular}

\section{Semi-structured interviews}

The semi-structured interviews commenced with short questions about factual data, like the type of elective supervised, job title, the number of Dutch students supervised. The subsequent topics were: the supervisor's motivation for supervising Dutch students, the actual supervisor role (activities undertaken with exchange students); critical incidents involving Dutch students, related to a learning situation during the elective; cultural differences that may have played a role in these incidents; overall evaluation of Dutch students' international electives. The supervisors were asked to describe the most positive and the most negative event involving Dutch students. For this part of the interview, the critical incidents technique was used, with interviewees being asked to describe incidents (events and behaviour) rather than their perceptions of them, which has the advantage of producing information that is less pre-interpreted. ${ }^{24}$ 
The principal author interviewed the supervisors in the period from SeptemberOctober 2003. The interviews lasted 40 minutes on average (range 25-75 minutes). The supervisors were interviewed at their work sites (cases 1 and 2) or in a quiet spot at the NetworkTUFH conference (case 3).

\section{Direct observations}

The principal author paid several field visits to elective sites and interviewed the Australian supervisors at their work sites. The field visits allowed to personally observing university departments, hospitals and their surroundings. She stayed one week at the Department of Rural Health, Sydney University, at Broken Hill. Financial constraints precluded field visits to case 3 sites.

The principal author's unstructured direct observations provided additional information about the topic under study. ${ }^{23}$ The conference posters in the corridors of the Department of Diving and Hyperbaric Medicine, in Sydney, for instance, bore witness to Dutch students' involvement in departmental research projects. Street life in Wilcannia (Australian outback) revealed the high percentage of Aboriginal people living there, as well as their poor living conditions. These observations provided context for the analyses of the interviews.

\section{Analyses}

\section{Analyses}

The interviews were tape-recorded and transcribed verbatim. Transcripts were analysed using Atlas-ti (Version 4.1) computer software package. (The Atlas-ti computer program is especially designed for qualitative analyses).

- Firstly, the interviews of each case were analysed separately. Analysis involved line by line scrutiny of the transcripts, with keywords being assigned to text fragments (open coding). For each interview, categories and themes were identified, tested and refined in a cyclic process, involving repeated analysis of both previous and following interviews (axial coding). This type of analysis resembles the open coding and axial coding phases of grounded theory. ${ }^{25,26}$ These analyses served as the basis for interview summaries, which were used for pattern matching and member checks.

Pattern matching involves comparing an empirical pattern with a predicted one. $^{25}$ It was used in two ways:

- (Pattern-matching involved) Categorising the learning processes described by the interviewees as guided, experiential or self-directed learning processes (within each of the three separate cases) in accordance with the definitions given in the introduction. The findings of our earlier study ${ }^{17}$ had led us to expect that most of the learning processes would be categorised as experiential learning. 
- (Pattern-matching involved) Making an inventory of the 'cultural differences' described during the interviews (within each of the three separate cases). Because of the relatively close resemblance between the Netherlands and Australia on three 'national culture' dimensions, i.e. individualism, power distance and avoidance of uncertainty, we expected case 2 to yield few instances of cultural differences. Case 1 was expected to reveal more effects of cultural differences, because of the likely encounters with indigenous (Aboriginal) patients. The likelihood of establishing an effect of cultural differences was considered greatest in case 3, because these electives were set in host countries that differed most from the Netherlands in 'national culture'.

- Finally, cross case analysis was conducted, involving comparison of the findings for the three different cases.

\section{Quality Checks}

To enhance the 'trustworthiness' of the results, i.e. to diminish subjectivity, several quality checks were performed. ${ }^{27}$

Member checks involved asking interviewees whether the summaries accurately reflected interview content. Of seventeen interviewees $(n=17)$, eleven responded and accepted the summaries as accurate. Five of them suggested minor corrections (e.g. spelling, subheadings). Six interviewees did not respond, even after two reminders (table 1).

Pattern matching was used for a quality check of the interview analyses. The principal author and one of the co-authors performed this independently for each of the three cases and discussed the results in bilateral meetings. Disagreements were few, particularly regarding the categorisation of learning processes. The pattern matching of the socio-cultural differences yielded a slightly higher number of differences between assessors. Consensus was easily reached after mutual adjustments.

\section{Results}

The results of the pattern matching of learning processes and socio-cultural differences will be described for each case. Illustrative citations from interviews will be given especially for socio-cultural differences, because these concepts were less clear-cut than the definitions of the learning processes. 


\section{Case 1 The Australian outback}

\section{Learning processes}

The six-week clinical elective at Broken Hill was undertaken by students in Years 3 through 6. Students spent some four weeks in different departments of Broken Hill Base Hospital (Emergency, Haematology, Surgery), approximately two weeks at Wilcannia Health Service and some days at Aboriginal Primary Healthcare Services (Broken Hill) or ambulance service. Ten different supervisors described learning processes that were all categorised as experiential learning. One supervisor, i.e. the programme coordinator, who was the only nonclinical supervisor, described a learning process that was categorised as guided learning. The programme coordinator played a key role in the socio-cultural integration of Dutch students. Some of the critical incidents mentioned by supervisors may have involved self-directed learning. Although supervisors were positive about how students had designed these learning processes, they gave no indication of having actively stimulated self-directed learning.

Supervisor 9

“. . A pair of Dutch students that have worked with me on the ward came back after two weeks of work in Wilcannia and presented a report on their experience. It was among the most professional assessments of the scene in Wilcannia that I've ever received. These people were able to prepare and present to a group of senior colleagues the results of their experiences within a culture which is so foreign to where they come from, that should have been a challenge to anybody."

\section{Socio-cultural differences}

All supervisors were very positive about the Dutch students. They said the students fitted in well with (ward) routine and had excellent diagnostic, communication and social skills. The lack of complaints from nurses and patients was mentioned as an indication of the Dutch students' excellent functioning. Supervisor 9

"They do the procedures we need them to do, quite competently, but there are many smaller examples of how the Dutch students fit in well, they have the right skills to be able to fit in well with the ward routine, good knowledge base and very good command of the English language."

Nine supervisors recalled no negative critical incidents involving Dutch students, although some of them recalled negative critical incidents with Australian students who were rude or did not treat nurses or patients with respect and cases of arrogant students from other countries. 
The supervisors mentioned that Dutch students picked up regional language differences with ease and experienced the same language problems as Australian students from non-English speaking backgrounds or from the Australian cities. The supervisors had noticed no substantial cultural differences between Australia and the Netherlands, but acknowledged that there were large socio-cultural differences in relation to indigenous Aboriginal people. However, the Dutch students showed a good understanding of Aboriginal culture and it was mentioned that they fitted in better with Aboriginal culture (and in Wilcannia) than a lot of Australian students from the cities.

Supervisor 7

"I think socio-cultural differences play a large role. There are lots of many different cultures in the Aboriginal communities and a lot of white, city born people don't appreciate or understand that. . . I think the Dutch people are probably much better on that road than a lot of Australian medical people, that's just my feelings."

Several supervisors mentioned the first two Dutch students who came for an elective, who had set a good example in many respects (language, integration, skills) and seemed to have cleared the way for the Dutch students after them.

Finally, two negative critical incidents were disclosed by the programme coordinator. One arrogant Dutch student had disrupted the ambulance elective by taking over from Australian students (who did not want to do the elective) and because the student failed to report the swap, insurance-related matters had caused considerable trouble for the coordinator afterwards. The other incident concerned a Dutch student from an Asian background, who had too much difficulty with the English language. (The fact that none of the other supervisors mentioned this as a negative incident may have been due to them not having realised that this student was Dutch, due to her Asian appearance.)

\section{Case 2 Australian urban areas}

\section{Learning processes}

The electives at Australian urban sites consisted of 3-month science projects in Diving and Hyperbaric Medicine in Sydney undertaken by students in Years 46, 6-week clinical electives in Neurology and Paediatrics, respectively, in Melbourne by students in Years 3-6. The learning processes during the science projects and the clinical electives were categorised as guided learning and experiential learning, respectively. The supervisors of the clinical electives mentioned critical incidents involving processes that might be described as self-directed learning, but, despite their clearly positive views of how students had designed these learning processes, the supervisors in no way indicated that they had encouraged these processes. 
Supervisor 3

"Many of our students can be very passive and these six Dutch students took a very active role in their learning . . These six were able to work so efficiently without much supervision, without any supervision really."

\section{Socio-cultural differences}

The three supervisors unanimously regarded the Dutch students as very active. They had not noticed substantial socio-cultural differences, although one supervisor mentioned that some Dutch students did not have a sufficient command of English to appreciate the subtleties of what patients were trying to tell them. Supervisor 1

"Let's say you have about twenty and you have two of them whose language wasn't good enough. . . We can have a conversation, but when they talk to patients they may miss the subtlety of what they are trying to say to them".

None of the supervisors recalled any negative critical incident involving Dutch (Maastricht) students.

\section{Case 3 Non-Western countries}

\section{Learning Processes}

The case 3 elective sites offered 6-week clinical orientation electives in community oriented Paediatrics and Tropical Diseases (Kenya), community oriented Public Health (Mexico) and community oriented Obstetrics and Gynaecology (Philippines).

The supervisors described learning processes that were categorised as experiential learning processes. Some critical incidents may have involved self-directed learning processes, but supervisors, despite taking a positive view of these learning processes, made no mention of having stimulated them.

Supervisor 18

"They informed me that they were coming to the hospital as well; they didn't only stay in the community. They did not abandon the Health Centre; they sometimes work 24 hours, because they were willing to do so."

\section{Socio-cultural differences}

The Kenyan supervisors said that, because of their many years of experience as students in Europe, they had no difficulty communicating with Dutch students. The supervisors acknowledged that Dutch students might experience culture shock, although this never caused serious problems. One supervisor tried to 
overcome culture shock by giving students a short introduction to socio-cultural differences, for example the use of drinking water supplies, and by introducing foreign students to indigenous students who had been abroad. Poverty could be a shock to students as well.

Supervisor 20

"The only social-cultural problems that I met with them, is that sometimes they are over-thrilled when they see patients. They get a shock because maybe three patients are sharing a bed and sometimes they would like to take a photograph."

Both Kenyan supervisors mentioned as a very positive quality of Dutch students that they were compassionate and committed to patients and people in general. Supervisor 20

"They are very compassionate; they also asked me to show them where the orphanage for children is so they come with a mind of human nature."

The Mexican supervisor saw the Dutch students as active students who behaved respectfully towards patients and had only occasional communication problems due to poor command of Spanish. To illustrate socio-cultural differences, he mentioned that Dutch students learned a lot from the much warmer and stronger family ties in his country.

Supervisor 18

"When she left she said that the first thing she would do when back home, was to tell her father how much she loved him, because seeing my secretary treating her father and seeing how the relationship was, so warm, she thought of herself being quite distant ..."

The Philippine supervisor illustrated socio-cultural differences with the example of the professor whose jocular style in talking about a gynaecology subject had been interpreted by Dutch students as sexual harassment.

Supervisor 19

"We did not think of sexual harassment as we knew the professor's joking style. While we are conservative too, we were not intimidated. Perhaps because we just don't pay attention to the particular professor when he jokes in class. We just keep quiet and so he stops joking."

All supervisors mentioned that Dutch students were very active. The Philippine supervisor mentioned additionally that international students seemed to belong to a special group of bright and strongly motivated students. The Mexican and Philippine supervisors both regarded Dutch students as very eager to get handson learning experiences. 
Again the supervisors did not recall any negative critical incidents involving Dutch (Maastricht) students.

\section{Cross cases}

We will now present a comparison of the findings from the three cases.

\section{Learning processes}

As expected, experiential learning proved to be the dominant learning process in each of the three cases. 'Guided learning' processes were described twice: for an elective involving science projects (case 2) and by a non-clinical supervisor (case 1). Interestingly, the other electives were all clinical electives described by clinician-supervisors.

Self-directed learning may have occurred in a few instances within each case, but it was never actively stimulated by supervisors.

\section{Socio-cultural differences}

Case 1 yielded the expected socio-cultural differences. Dutch students fitted in well with the organisational structure of Australian health care. Although relating to (Aboriginal) patients was mentioned as a potential difficulty, Dutch students managed to deal respectfully with (indigenous) patients.

As expected, there were almost no socio-cultural differences in case 2 .

Case 3 yielded the greatest number of socio-cultural differences, which was as expected. The potential danger of culture shock was mentioned and sociocultural differences were related to the organisational structure of medicine, medical education, student/teacher relationship and personal relationships. A good example of a difference on Hofstede's Power Distance dimension (1986) ${ }^{21}$ was given by the Philippine supervisor (no 19) to illustrate that teachers in the Philippines were never contradicted or publicly criticised, whereas in the Netherlands this is quite acceptable.

Language was mentioned as a source of socio-cultural differences in all cases. Case 1 and 3 yielded instances where language problems were explicitly mentioned as a cause of communication problems.

Supervisors in all cases recalled hardly any negative critical incidents involving Dutch students. Social desirability may have coloured supervisors' responses. There was, however, countervailing evidence that arose during the principal researcher's visit to Broken Hill where two Dutch Year 6 students were offered jobs in the Emergency Department. This clearly reflected the supervisor's appreciation of the students' work. 


\section{Discussion}

The aim of our study was triangulation using findings from earlier studies on learning from international electives and findings from another source, i.e. external supervisors. We explored the research questions: 'What is the nature of undergraduate medical students' learning processes from international electives?' and 'are socio-cultural differences experienced during these learning processes? Our findings showed that the vast majority of students' learning processes as described by external supervisors were best characterised as 'experiential learning'. The findings also suggest that the greater the cultural differences between elective site and the Netherlands, the higher the number of sociocultural differences reported by supervisors. Presumably, the greater the differences between national cultures, the greater the likelihood of such differences standing in the way of productive learning.

The results of this study were largely consistent with our earlier findings on learning processes from students self-reports. ${ }^{17}$ Students described slightly more learning processes as being self-directed. This is probably due to how we defined the learning processes, with self-directed learning requiring active stimulation by supervisors. Thus some students' learning processes which were categorised as experiential may actually have constituted self-directed learning that was not supported by the (external) supervisors. The point we wish to make in this respect is that not all students are capable of designing their own learning processes and many will need support from supervisors to achieve self-directed learning. ${ }^{18}$ Students and supervisors will need additional skills to facilitate selfdirected learning. Student strategies to effect a shift towards 'self-directed learning' include goal-directed learning, diagnostic learning and reflective learning. These strategies require process-oriented instruction focused on the development of processes like self-regulation of learning and thinking integrated in regular domain-specific instruction. In process-oriented instruction, processes and skills are modelled by teachers (and fellow students) with teachers also acting as external monitors of students' learning, thinking and regulatory activities. Gradually, teachers withdraw these monitoring activities and other kinds of teacher control, as students' abilities to work independently increase. This is referred to as scaffolding. ${ }^{18}$

The results of this study are largely consistent with our earlier findings from students' self-reported experiences of socio-cultural differences between them and their supervisors. ${ }^{17}$ The dimensions of national cultural differences as developed by Hofstede $(1986)^{21},(1996)^{22}$ were useful in predicting and explaining socio-cultural differences. 
So far there appears to be no consensus about any extras that international electives should deliver to undergraduate medical students. However, there is no denying that the socio-cultural dimension might potentially offer added educational value. Thus we recommend exploration of ways to transform sociocultural differences between students and supervisors from a potential barrier to the effectiveness of learning into an integral part of student learning experiences. This might be achieved by having students prepare, elaborate and reflect on critical events relating to socio-cultural differences between them and their supervisors.

The results of this study do not elucidate whether experiential learning processes are typical characteristics of international electives only. International electives might be seen as a comparable learning environment to regular clinical rotations. Recent Dutch and American studies concluded that learning during such rotations appeared to be an unstructured, rather haphazard process. ${ }^{28,30}$ An Australian study ${ }^{31}$ on learning in surgical clerkships showed that students reporting that they found theatres useful learning environments had (among other things) a measure of social competence, and opportunity, to negotiate an active part in the team as a legitimate learner in the training queue (behind the intern, the resident, the registrar and the surgical fellow). The importance of the supervisor role in regular clinical rotations is also stressed by students. ${ }^{32,33}$ Finally, it is also acknowledged that healthcare is rarely delivered in a mono-cultural context. ${ }^{34,35}$ Hence it seems safe to assume that a comparison between undergraduate international clinical electives and regular clinical rotations will reveal more similarities than differences.

In "New Learning", Simons et al. (2000) ${ }^{18}$ advocate a balance between 'experiential learning', 'self-directed learning' ànd 'guided learning'. We agree with them that students should be enabled to use all these learning processes in an iterative way. In a prior study, we recommended more self-directed learning, because students who used more self-structured learning processes were found to be more successful in achieving their learning goals. ${ }^{17}$ The results of the current study suggest that we should recommend also more 'guided learning', particularly in preparing students to cope with socio-cultural differences (during international electives) and to elaborate and reflect on these differences.

More research is needed to evaluate the effectiveness of international clinical electives. It will also be a challenge to control for the myriad of confounding factors that may play a role in this field. ${ }^{14,36} \mathrm{~A}$ worthwhile subject for further study might be indications from prior studies that students going on international electives may be a self-selected group. ${ }^{13,16}$ New insights into this subject may be obtained by comparing the characteristics of students who do and students who 
do not go on international electives. Such a study should focus on student learning styles and cultural sensitivity. In addition, it would be helpful to strive for consensus on the intended outcomes that international electives should deliver for undergraduate medical students.

The limitations of this study are the small numbers studied and a potential effect of social desirability on interviewees' statements. However, we included several quality checks in the study. The positive outcomes of pattern-matching may be taken as a measure of the study's internal validity. ${ }^{23}$

\section{References}

1. Van der Wende MC. Globalisation and access to higher education. Journal of studies in International Education 2003;7:193-206.

2. Eckhert NL. The global pipeline: too narrow, too wide or just right? Medical Education 2002;36:606-13.

3. Unwin E, Alberti G, Aspray T, Edwards R, Mbanya J, Sobngwi, Mugusi F, Rashid S, Setel P, Whiting D. Economic globalisation and its effect on health. British Medical Journal 1998;316:1401-2.

4. Bateman C, Baker T, Hoornenborg E, Ericsson U. Bringing global issues to medical teaching. Lancet 2001;358:1539-42.

5. Schwarz MR. Globalization and medical education. Medical Teacher 2001;23:533.

6. Edwards R, Rowson M, Piachaud J. Teaching international health issues to medical students. Medical Education 2001;35:807-8.

7. De Wit JWM. Internationalisation of higher education in the United States of America and Europe. Amsterdam: University of Amsterdam PhD Thesis, 2001.

8. Knight J. Monitoring the quality and progress of internationalisation. Journal of Studies in International Education 2001;5:228-43.

9. Majoor GD \& Willemstein SC. Internationalisering van het medisch onderwijs. (Internationalisation of medical education.) Nederlands Tijdschrift Geneeskunde (Dutch Journal of Medicine) 1996;140:100.

10. Van der Wende MC. Internationalising the Curriculum in Dutch Higher Education: an International Comparative Perspective. Utrecht: University of Utrecht PhD Thesis, 1996.

11. Teichler U. Changes of ERASMUS under the umbrella of SOCRATES. Journal of Studies in International Education 2001;5:201-227.

12. Niemantsverdriet S, Majoor GD, Scherpbier AJJA, van der Vleuten CPM Internationalisation of medical education in the Netherlands: state of affairs. Medical Teacher 2006a;28:187-89.

13. Godkin MA, Savageau JA. The effect of a global multiculturalism track on cultural competence of preclinical medical students. Family Medicine 2001;33:178-86.

14. Thompson MJ, Huntington MK, Hunt DD, Pinsky LE, Brodie JJ. Educational effects of international health electives on US and Canadian medical students and residents: A literature review. Academic Medicine 2003;78:342-7.

15. Azad N, Power B, Dollin J, Chery S. Cultural Sensitivity Training in Canadian Medical Schools, Academic Medicine 2002;77:222. 
16. Niemantsverdriet S, Majoor GD, Scherpbier AJJA, van der Vleuten CPM. I found myself a down-to-earth Dutch girl: a qualitative study into learning outcomes from internships abroad. Medical Education 2004;38:749-57.

17. Niemantsverdriet S, van der Vleuten CPM, Majoor GD, Scherpbier AJJA. An explorative study into learning on international internships; experiential learning processes dominate. Medical Education 2005;39:1236-42.

18. Simons PRJ, van der Linden J, Duffy T. New learning: three ways to learn in a new balance. In Simons PRJ, van der Linden J, Duffy T. (Eds), New Learning (pp 1-20). Dordrecht: Kluwer Academic Publishers, 2000.

19. Van Hout-Wolters B, Simons PRJ, Volet S. Active learning: self-directed learning and independent work. In Simons PRJ, van der Linden J, Duffy T. (Eds) New Learning (pp 21-36). Dordrecht: Kluwer Academic Publishers, 2000.

20. Volet SE. Learning and motivation in context: A multi-dimensional and multi-level cognitivesituative perspective. In: Volet, S.E., Järvelä, S. (Eds) Motivation in learning contexts: Theoretical advances and methodological implications. London: Elsevier, 2001.

21. Hofstede G. Cultural differences in teaching and learning. International Journal of Intercultural Relations 1986;10:301.

22. Hofstede G. Difference and danger: cultural profiles of nations and limits to tolerance, Higher Education in Europe 1996;XXI:73.

23. Yin RK. Case study research: Design and Methods. London: Sage, 1994.

24. Flanagan JC. (1954) The critical incident technique, Psychological Bulletin 1954;51:327.

25. Strauss AL. Qualitative Analysis for Social Scientists. Cambridge: Cambridge University Press, 1987.

26. Wester F. Strategieën voor kwalitatief onderzoek. (Strategies for qualitative inquiry.) Bussum: Coutinho, 1995.

27. Lincoln YS, Guba G. Naturalistic Inquiry. Newbury Park: Sage, 1985.

28. Van der Hem-Stokroos HH, Scherpbier AJJA, Van der Vleuten CPM, De Vries H, Haarman HJThM. How effective is a clerkship as a learning environment? Medical Teacher 2001;23:608.

29. Daelmans HEM, Hoogenboom RJI, Donker AJM, Scherpbier AJJA, Stehouwer CDA, Van der Vleuten CPM. Effectiveness of clinical rotations as a learning environment for achieving competences, Medical Teacher 2004;26:305.

30. Hoffman KG, Donaldson JF Contextual tensions of the clinical environment and their influence on teaching and learning. Medical Education 2004;38:448.

31. Lyon PMA. Making the most of learning in the operating theatre: student strategies and curricular initiatives. Medical Education 2003;37:680.

32. Dolmans DHJM, Wolfhagen HAP, Essed GGM, Scherpbier AJJA, Van der Vleuten CPM. Students' perceptions of relationships between some educational variables in the out-patient setting. Medical Education 2002a; 36:735.

33. Dolmans DHJM, Wolfhagen HAP, Essed GGM, Scherpbier AJJA, Van der Vleuten CPM. The impacts of supervision, patient mix, and numbers of students on the effectiveness of clinical rotations, Academic Medicine, 2002b;77:332.

34. Prideaux D. \& Edmondson W. (2001) Cultural identity and representing culture in medical education. Who does it? Medical Education 2001;35:186.

35. Wear D. Insurgent Multiculturalism: Rethinking how and why we teach culture in medical education, Academic Medicine 2003;78:549.

36. Edwards R, Piachaud J, Rowson M, Miranda J. Understanding global health issues: are international medical electives the answer? Commentary Medical Education 2004;38:688. 


\title{
Chapter 6
}

\section{What Should Be Learning Outcomes? ${ }^{1}$}

\begin{abstract}
Objective: In the introduction we review the empirical evidence that the learning of students in international internships may benefit when the learning processes of these students are better structured. A minimal requirement for structuring is having defined learning outcomes. This led to the research question: 'What are the desired learning outcomes of international internships of undergraduate medical students?'

Method: A Delphi procedure with international experts was conducted. Stability in the answers was reached after two rounds.

Results: The final framework of desired learning outcomes consisted of the following domains: Medical Knowledge, Clinical Skills, Communication Skills, Intercultural Skills, Academic Development, Health Care in the host country, Knowledge about Society and Culture of the host country, Personal Growth, Professional Development.

Conclusion: We recommend that students going abroad and their supervisors use the final framework as a guideline in developing learning outcomes. Obviously, there are more ways of structuring learning processes, such as tighter organisation of international internships programmes or instructions for supervisors. For a start, however, facilitating the structuring of learning processes by offering suggestions for learning outcomes seems to be a (cost) effective way.
\end{abstract}

\footnotetext{
${ }^{1}$ This chapter has been submitted as: Niemantsverdriet S, van der Vleuten CPM, Majoor GD \& Scherpbier AJJA. A Delphi procedure for desired learning outcomes of International Internships.
} 


\section{Introduction}

Internationalisation of education activities mainly consists of students going abroad for internships. ${ }^{1,2}$ International internships can be viewed as an excellent opportunity for students to learn in a primary learning context, where the learner engages in authentic tasks. ${ }^{3}$ However, real life contexts in themselves are no guarantee of good learning outcomes. International internships in higher education do not always appear to be all that effective. ${ }^{4}$ In one of our previous studies, some students reported having performed very advanced tasks during their international internships, whereas others recounted very limited (hands-on) learning experiences. ${ }^{5}$ In this introduction, we will argue that a good way of enhancing the effectiveness of learning processes during international internships is to structure students' learning processes by defining clear learning outcomes.

In previous studies concerning learning from internships abroad, we concluded that students' learning processes matched guided, self-directed, and experiential learning processes. These three types of processes differ in the way learning is structured. ${ }^{6}$ In 'guided learning', the teacher structures most of the learning functions (preparatory, executive and closing functions), in 'self-directed learning' it is the students who structure their learning, and in 'experiential learning', learning is an unstructured side effect of activities. With fully self-directed learning, supervisors still have different roles to play, such as those of coach, expert, consultant and role model. Table 1 presents an overview of learning processes and learning functions. Interviews with students ${ }^{7}$ and international supervisors ${ }^{8}$ revealed that the learning processes of the majority of the students in international internships matched the experiential learning process.

What students practised and learned proved to be unrelated to year of study, type of internship or country visited. ${ }^{5}$ The results suggest that students' learning processes may (at least partially) explain differences in learning outcomes. Where the learning processes of most students consist of experiential learning (learning as an unstructured side effect of activities), learning outcomes are likely to be diverse and unpredictable. However, students who adopted more structured learning processes (self-directed or guided) succeeded in reaching their intended outcomes.

Hence a balance in learning processes is advocated. ${ }^{9}$ Not only experiential, but also self-directed and guided learning processes should be stimulated in international internships. A minimal requirement for achieving more structured learning processes is to define learning outcomes. ${ }^{10}$ In problem-based learning environments students generate learning issues from different sources, such as discussions in tutorials, tutors, lectures and course objectives. ${ }^{11,12}$ However, students' learning during (international) internships differs from learning in settings 
like problem based group learning or classroom learning in that there are no direct sources of learning outcomes. ${ }^{13}$ Therefore in (international) internships sources of learning outcomes should be provided. Studies have shown that when students receive guidance from experts on entering a new learning area, they are likely to become more independent learners at later stages. ${ }^{11,12}$

To provide suggestions for learning outcomes and therewith foster more structured learning processes during internships abroad (self-directed and guided), we formulated the following research question: 'What are desired learning outcomes of international internships for undergraduate medical students?'

Table 1 An overview of learning processes and the way they are structured by learning functions.

\begin{tabular}{|c|c|c|c|}
\hline \multirow{2}{*}{$\begin{array}{l}\text { Learning } \\
\text { Processes }\end{array}$} & \multicolumn{3}{|c|}{ Learning Functions* } \\
\hline & Preparation & Execution & Closing \\
\hline Guided Learning & + & + & + \\
\hline Self Directed Learning & + & + & + \\
\hline Experiential Learning & - & + & - \\
\hline
\end{tabular}

*) ‘+' Indicates a learning function is fulfilled; '-' Indicates a learning function is unfulfilled

\section{Methods}

\section{Method}

Murry \& Hammons (1995) ${ }^{14}$ define a Delphi procedure as: "a method for the systematic solicitation and collection of judgements on a particular topic through a set of carefully designed sequential questionnaires interspersed with summarized information and feedback of opinions derived from earlier responses". The procedure continues until consensus or stability in panel members' responses is reached. Typical for the Delphi method is: (1) consultation of an emancipated research field; (2) in an anonymous way; (3) in different rounds (4) with feedback of results (5) and with the possibility for participants to change their points of view. ${ }^{15}$ A Delphi procedure seemed the most suitable method for this study, because it avoids the bias of dominant views in group discussions, which would play a role in for instance focus group research. An additional advantage of a Delphi procedure is that it is relatively easy to consult panel members who are spread out geographically. 


\section{Subjects}

Obviously the findings of a Delphi study will be affected by the composition of the panel. Selection criteria for the experts on the panel were:

- recently graduated or final year medical students who had experienced at least one international internship;

- (foreign) supervisors of undergraduate medical students on international internships;

- policy makers (international relations officers, deans of medical faculties, directors of educational programmes);

- researchers of student mobility.

It was expected that these different types of experts would all have ideas about outcomes of international student mobility because of their (in-)direct involvement in student in this field. Furthermore, with this selection of experts, different interests, viewpoints, contexts, expertise and field experiences would be represented. ${ }^{15}$

On the basis of these criteria a panel of experts was composed. It resulted in a rough list of 222 potential experts. It is likely that this list of experts also contained experts who did not meet the selection criteria, because data about their involvement in mobility were not always available. Therefore the selection of experts also depended on willingness of key persons to supply addresses.

\section{Delphi Procedure and Materials}

In Round 1, the design of the framework started from a framework developed in an earlier study. ${ }^{5}$ This framework comprised six domains of learning outcomes: medical knowledge, skills, international health care, international medical education, society and culture, and personal growth. This framework was extended to eight domains to make it suitable for the present study. The extension resulted from re-arranging the 'skills domain' into three different domains: clinical skills, intercultural skills, and academic development. The description of the domain of academic development was derived from the literature. ${ }^{16}$

In a pilot, an expert on methodology and an expert on competence assessment evaluated the Delphi questionnaire, including the adapted framework. On the basis of the comments of the two experts, the questionnaire was adapted in several ways. In the letter inviting participants to fill in the questionnaire, the instructions were expanded and the context of the study was described in greater detail. The open questions in the questionnaire were given more attention, with feedback being asked about each of the domains. The experts had to rate the relevance of the items and open questions in respect of the different types of international internships in medicine: electives (6 weeks), clinical clerkships (6 weeks) and research internships (12 weeks). Figure 1 shows the definitions of the different internships. 
Figure 1 The definitions of internships that were used in the questionnaires.

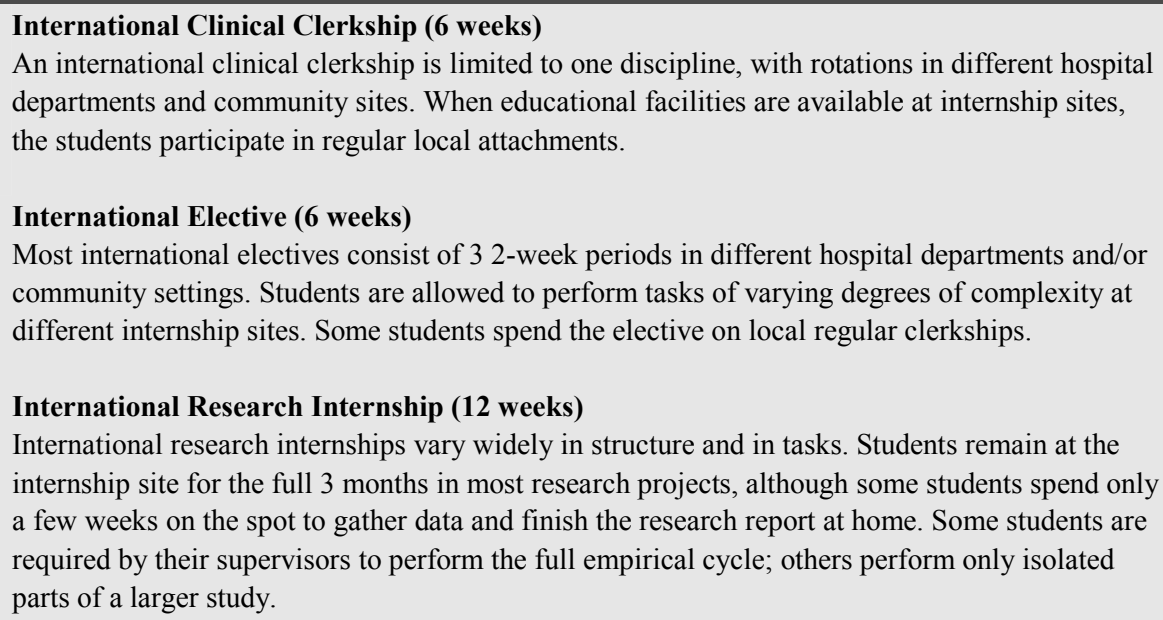
departments and community sites. When educational facilities are available at internship sites, the students participate in regular local attachments.

\section{International Elective (6 weeks)}

Most international electives consist of 32 -week periods in different hospital departments and/or community settings. Students are allowed to perform tasks of varying degrees of complexity at different internship sites. Some students spend the elective on local regular clerkships.

\section{International Research Internship (12 weeks)}

International research internships vary widely in structure and in tasks. Students remain at the internship site for the full 3 months in most research projects, although some students spend only a few weeks on the spot to gather data and finish the research report at home. Some students are required by their supervisors to perform the full empirical cycle; others perform only isolated parts of a larger study.

An electronic Delphi questionnaire was developed. It consisted of 24 items to be answered on a five-point Likert scale, four open questions and some questions about personal background. The introductory letter and the questionnaire were e-mailed to potential experts.

The results of Round 1 of the Delphi questionnaire were processed and presented in a new questionnaire and returned to the experts who had completed it. The Delphi-questionnaire for Round 2 contained an adapted version of the framework, the group scores for relevance of the different domains, the personal ratings and the possibility to re-rate the individual scores. In addition, it contained some open questions asking for comments on the changes. This Delphi procedure resembles the approach proposed by Murry \& Hammons $(1995)^{14}$ and by $\operatorname{Koster}(2001)^{15}$.

\section{Analysis}

The answers to the open questions of Round 1 were analysed using the computer software Atlas-ti (Version 4.1). Analysis involved line by line scrutiny of the full answer texts, with keywords being assigned to text fragments. Categories were identified on the basis of the keywords and tested and refined through repeated analysis. ${ }^{17}$ The answers to the open questions of Round 2 were analysed in the same way.

The answers to the closed questions and the Likert type questions were analysed using the computer software SPSS (Version 13.0). The scores (1-5) of the experts for the relevance of the domains in the framework in respect of the different types of internships (clinical clerkship, electives, and research internships) 
were calculated. The scores were summed by domain and scores 4 (relevant) and 5 (very relevant) were collapsed. Group scores of 75 percent or higher were considered as consensus, which resembles the approach used by Tigelaar et al. (2004). ${ }^{18}$

Table 2 Number of Experts participating in Round $1(\mathrm{n}=55)$ and Round $2(\mathrm{n}=36)$ by University and Position.

\begin{tabular}{|c|c|c|c|c|c|c|c|c|}
\hline \multirow[t]{2}{*}{$\begin{array}{l}\text { Type of } \\
\text { Expert }\end{array}$} & \multicolumn{2}{|c|}{$\begin{array}{c}\text { Universities } \\
\text { Outside } \\
\text { Europe* }\end{array}$} & \multicolumn{2}{|c|}{$\begin{array}{l}\text { Maastricht } \\
\text { University }\end{array}$} & \multicolumn{2}{|c|}{$\begin{array}{l}\text { Leiden } \\
\text { University }\end{array}$} & \multicolumn{2}{|c|}{$\begin{array}{l}\text { Other Dutch } \\
\text { Universities }\end{array}$} \\
\hline & $\begin{array}{c}\text { Round } \\
1 \\
\end{array}$ & $\begin{array}{c}\text { Round } \\
2\end{array}$ & $\begin{array}{c}\text { Round } \\
1\end{array}$ & $\begin{array}{c}\text { Round } \\
2\end{array}$ & $\begin{array}{c}\text { Round } \\
1\end{array}$ & $\begin{array}{c}\text { Round } \\
2\end{array}$ & $\begin{array}{c}\text { Round } \\
1 \\
\end{array}$ & $\begin{array}{c}\text { Round } \\
2\end{array}$ \\
\hline $\begin{array}{l}\text { (Recently } \\
\text { graduated) }\end{array}$ & & & & & & & & \\
\hline Student & - & - & 6 & 5 & 5 & 3 & 2 & 1 \\
\hline Supervisor & 3 & - & 13 & 8 & 14 & 11 & 2 & 2 \\
\hline Policymaker** & 2 & 2 & 3 & 2 & 3 & 0 & 2 & 2 \\
\hline Total & 5 & 2 & 22 & 15 & 22 & 14 & 6 & 5 \\
\hline
\end{tabular}

*) Mozambique, Canada, Ecuador, Australia, Philippines

**) Dean, International Officer, Director of Educational Programme

\section{Results}

\section{Response}

222 potential experts were invited to participate in the Delphi procedure. In Round 1, 55 of 69 respondents met the selection criteria and were invited to sit on the panel. Fifty experts were affiliated to Dutch universities (for the greater part Maastricht and Leiden). Five experts were from universities outside Europe. Unfortunately, student mobility researchers were too few to form a separate group of experts. In Round 2, 36 respondents filled out the questionnaire. Nonresponders (after one reminder) resided equally in all categories of universities and experts. More detailed information about the experts is shown in table 2.

\section{Open questions in Round 1}

The answers to the open questions in Round $1(n=55)$ were divided over the following seven categories in a bottom up process: clear (122x); no answer (92x); add something to the domain or sub-item (28x); comments on the objective of the framework $(11 \mathrm{x})$; comments on the framework of domains $(5 \mathrm{x})$; re- 
marks outside the scope of the Delphi study (5x); something not clear (12x). Illustrative excerpts from answers to the open questions are shown in table 3 . The adjustments proposed by the experts in Round 1 were incorporated into the framework of domains for Round 2. One new domain was added, i.e. 'professional development'. The 'clinical skills' domain was subdivided into 'clinical skills' and 'communication skills', and several sub-items were added to domains, such as ability to work with less/different diagnostic means, language skills and ability to co-operate.

Remarks referring to matters outside the scope of the Delphi procedure could not be integrated, although it should be acknowledged that these items were relevant to student mobility. They concerned for example: financial aspects, international administration, ECTS study points and broken love relationships.

Table 3 Categories of answers to open questions in Round $1(n=55)$.

\section{Categories Excerpts from answers to open questions}

Add something to domains or sub items (28x)

Something not clear

(12x)

Comments on the objective of the framework of domains (11x)

Comments on the framework of domains $(5 \mathrm{x})$

Remarks beyond the objective of the Delphi (5x)
"Being able to perform well clinically, even though you do not have the diagnostic tools you are used to or do not get a full history you are used to."

"The issue of language was not explicitly addressed and that might be important."

"Add reflection on the way healthcare works in different settings."

"In clinical skills, physical examination should be added, as (most of the times) one is able to perform more physical examinations than in an internship in the Netherlands."

“Academic skills were not completely clear to me."

"Students who want to study abroad must be motivated and meet demands; it will generate qualitatively different learning outcomes."

"There is a relationship between Culture \& Society on the one hand and Intercultural Skills on the other."

"I miss financial aspects, some of my students had to end their stay due to lack of money." 
Table 4 Percentages of experts giving ratings of $>3$ for the relevance of the domains for the different types of internships in Round 1 and Round $2(n=55$, respectively $n=36) .{ }^{1,2}$

\begin{tabular}{|c|c|c|c|c|c|c|}
\hline \multirow[t]{2}{*}{ Domains } & \multicolumn{2}{|c|}{$\begin{array}{c}\text { International } \\
\text { Clinical Clerkship }\end{array}$} & \multicolumn{2}{|c|}{$\begin{array}{l}\text { International } \\
\text { Elective }\end{array}$} & \multicolumn{2}{|c|}{$\begin{array}{c}\text { International } \\
\text { Research Intern- } \\
\text { ship }\end{array}$} \\
\hline & $\begin{array}{c}\text { Round } \\
1\end{array}$ & $\begin{array}{c}\text { Round } \\
2\end{array}$ & $\begin{array}{c}\text { Round } \\
1\end{array}$ & $\begin{array}{c}\text { Round } \\
2\end{array}$ & $\begin{array}{c}\text { Round } \\
1\end{array}$ & $\begin{array}{c}\text { Round } \\
2\end{array}$ \\
\hline Medical Knowledge & + & + & + & + & - & - \\
\hline Clinical Skills & + & + & + & + & - & - \\
\hline Communication Skills & + & + & + & + & - & - \\
\hline Intercultural Skills & + & + & + & + & - & - \\
\hline Academic Development & - & - & - & - & + & + \\
\hline $\begin{array}{l}\text { Health Care in the host } \\
\text { country }\end{array}$ & + & + & + & + & - & - \\
\hline $\begin{array}{l}\text { Medical Education in the } \\
\text { host country }\end{array}$ & - & - & - & - & - & - \\
\hline $\begin{array}{l}\text { Knowledge about Society } \\
\text { and Culture } \\
\text { of the host country }\end{array}$ & + & + & + & + & - & - \\
\hline Personal Growth & + & + & + & + & + & + \\
\hline Professional Development & new & + & new & + & new & + \\
\hline
\end{tabular}

$\left.{ }^{1}\right)+=\geq 75 \%$ of the experts scored 4 (relevant) or 5 (very relevant)

${ }^{2}$ ) $-=<75 \%$ of the experts scored 4 (relevant) or 5 (very relevant)

\section{Relevance of the framework of domains in Rounds $1+2$}

The adaptations of the framework, suggested in Round 1, were approved in Round 2. For example, the suggested subdivision of clinical skills into clinical skills and communication skills was accepted in Round 2. The proposed new domain 'professional development' was also accepted in Round 2. Other adaptations, such as adding sub-items to a domain or rephrasing sentences, were also accepted in Round 2. Thus the scores for the domain framework's relevance to the different internships (clinical internship, international electives, and research internships) were stable in Round 1 and Round 2, as is shown in table 4. The domain 'Medical Education in the host country' was considered irrelevant for all the internships. 'Academic Development' was considered irrelevant for clinical internships and electives. The only domains that were considered to be of relevance to Research Internships were: 'Academic Development', 'Personal Growth' and 'Professional Development.'

The final adapted and approved version of the framework is presented in Appendix 1 at the end of this chapter. 


\section{Answers to the open questions in Round 2}

The answers to the open questions in Round $2(n=36)$ were processed in the same way as in Round 1. The resulting categories were: 'clear aims of the framework' (33x); 'no general comments' $(24 \mathrm{x})$. The remaining categories are discussed below.

Six experts said they would like more information to be included in the questionnaire or in the introductory letter about the aims of the framework, the domains or the desired learning outcomes. Other experts commented on the 'Things to keep in mind' section of the framework (Appendix 1): 'study stage' might be rephrased as 'study phase' $(2 \mathrm{x})$; developmental stage of the country is not always easy to establish (1x).

In response to the question inviting 'general comments on the questionnaire in total' four experts indicated that they had problems with some of the group ratings for different internships. For example, it was said that intercultural skills should be a desired outcome for research internships as well; academic development and ethical development in particular should be desired learning outcomes for all international internships and not just for research internships. Two respondents indicated that they thought that more elaboration of the domains in respect of the research internships was desirable.

\section{Discussion and Conclusion}

\section{A framework of learning outcomes}

To arrive at a framework of desired learning outcomes, we addressed the research question: 'What are desired learning outcomes of international internships for undergraduate medical students?'

Surprisingly, 'Academic Development' was not considered relevant to clinical clerkships and electives. The same result was found for the generic skills of giving a presentation and ethical development (both sub-items of the domain 'Academic Development'). This may be due to the description of the domain and the presentation of the sub-items, with ethical development being at the bottom of the list. It may also be attributable to the definitions of the types of internships, which in practice may not be as distinct as our definitions suggest. In all, we are quite satisfied with the constructed framework; the validation procedure resulted in addition of a new domain ('Professional Development'), subdivision of the domain 'Clinical Skills' into 'Clinical Skills' and 'Communication Skills' and addition of several sub-items to domains (Appendix 1). 


\section{Structure the learning processes!}

We recommend that students and supervisors should use the framework in developing learning outcomes in order to make the learning processes during international internships more structured and more diverse. Of course there are more ways of structuring learning processes, such as more tightly organised international internship programmes or instructions for supervisors. Furthermore, as we argued in a previous study, ${ }^{8}$ not all of the students will be capable of designing their own learning processes and many will need support from supervisors to achieve self-directed learning. ${ }^{9,12}$ At the same time supervisors will need appropriate skills to be able to facilitate students' self-directed learning. Findings from empirical studies indicated that experienced supervisors did not manage a sudden, complete change from 'transmitters of content' to 'coaches of students' learning processes' ${ }^{19,20}$ Structuring learning processes by providing suggestions for learning outcomes, based on a framework of desired learning outcomes, seems to be a good (cost) effective first step.

Another interesting, (cost) effective approach might be to develop the learning outcomes of the framework into 'task-based learning,. 10,13,21

Task-based learning involves identification of tasks undertaken by 'a professional'. These tasks then become the focus of the learning process. Students are responsible for integrating their learning around the tasks; they are assisted in this process by study guides. In a further step, these study guides could be transformed into an instructional tool on the internet.

\section{Limitations}

A limitation of the study is the way the experts were recruited. It is not certain that we tracked down all the relevant experts in student mobility; although we did succeed in including a reasonable number of them in the panel. The high percentage of non-responders can probably be explained by the rough list, which must have contained a considerable number of people who did not meet the selection criteria. Another limitation is that the study was directed at Dutch undergraduate medical students. Further studies should explore the generalisability of the findings to other contexts.

\section{References}

1. Teichler U. Changes of ERASMUS under the umbrella of SOCRATES. Journal of Studies in International Education 2001;5:201-227.

2. Niemantsverdriet S, Majoor GD, Scherpbier AJJA, van der Vleuten CPM Internationalisation of medical education in the Netherlands: state of affairs. Medical Teacher 2006a;28:187-89.

3. Koens F, Mann KV, Custers EJFM \& Ten Cate OTJ. Analysing the concept of context in medical education. Medical Education 2005;39:1243-1249. 
4. Stronkhorst R. Learning Outcomes of International Mobility at Two Dutch Institutions of Higher Education. Journal of Studies in International Education, 2005;9:292-315.

5. Niemantsverdriet S, Majoor GD, Scherpbier AJJA, van der Vleuten CPM. I found myself a down-to-earth Dutch girl: a qualitative study into learning outcomes from internships abroad. Medical Education 2004;38:749-57.

6. Van Hout-Wolters B, Simons PRJ, Volet S. (2000). Active learning: self-directed learning and independent work. In Simons PRJ, van der Linden J, Duffy T. (Eds) New Learning (pp 21-36). Dordrecht: Kluwer Academic Publishers, 2000.

7. Niemantsverdriet S, van der Vleuten CPM, Majoor GD, Scherpbier AJJA. An explorative study into learning on international internships; experiential learning processes dominate. Medical Education 2005;39:1236-42.

8. Niemantsverdriet S, van der Vleuten CPM, Majoor GD, Scherpbier AJJA. The learning processes of international students through the eyes of foreign supervisors. Medical Teacher 2006b;28:e104-e111.

9. Simons PRJ, van der Linden J, Duffy T. New learning: three ways to learn in a new balance. In Simons PRJ, van der Linden J, Duffy T. (Eds), New Learning (pp 1-20). Dordrecht: Kluwer Academic Publishers, 2000.

10. Harden RM, Crosby J, Davis MH, Howie PW \& Struthers AD. Task-based learning: the answer to problem-based learning in the clinical years. Medical Education, 2000;34:391-397.

11. Dolmans HJM \& Schmidt HG. What drives the student in problem-based learning? Medical Education, 1994;28:372-380.

12. Miflin BM, Campbell GB \& Price DA. A conceptual framework to guide the development of self-directed, lifelong learning in problem-based medial curricula. Medical Education, 2000;34:299-306.

13. Dornan T, Hadfield J, Brown M, Boshuizen H \& Scherpbier AJJA. How can medical students learn in a self-directed way in the clinical environment? Design-based research. Medical Education 2005b;39(4):356-364.

14. Murry JWJ \& Hammons JO. Delphi: a versatile methodology for conducting qualitative research, The Review of Higher Education, 1995;18(4):423-436.

15. Koster B. Teacher educators under the microscope. The development of a professional profile for teacher educators and the effects of examining this profile on their self-diagnosis. Utrecht: $\mathrm{PhD}$ Thesis, 2001.

16. Holleman W, van den Berg I, Oost H, Thoolen B \& Admiraal W. (1998) Five definitions of Academic Development (Vijf definities van academische vorming.) THEMA, 1998;5:4-9.

17. Patton MC. Qualitative Evaluation and Research Methods. Newbury Park: Sage Publications, 1990.

18. Tigelaar DEH, Dolmans DHJM, Wolfhagen IHAP \& van der Vleuten CPM. The development and validation of a framework for teaching competencies in higher education. Higher Education, 2004;48:253-268.

19. Hoogveld, AWM, Paas F, Jochems WMG \& van Merrienboer JJG. Exploring teachers' instructional design practices from a systems design perspective. Instructional Science, 2002;30:291305.

20. Dornan T, Scherpbier A, King N, Boshuizen H. Clinical teachers and problem-based learning: A phenomenological study. Medical Education, 2005a;39(2):163-170.

21. Harden RM, Laidlaw JM, Ker JS \& Mitchell HE. AMEE Medical Education Guide No. 7. Task-based learning: an educational strategy for undergraduate, postgraduate and continuing medical education, Part 2. Medical Teacher, 1996;18:91-98. 


\section{Appendix 1}

Figure 2 A framework of domains of desired learning outcomes for different types of international internships.

\begin{tabular}{|c|c|c|c|}
\hline DOMAINS & $\begin{array}{l}\text { International } \\
\text { Clinical } \\
\text { Clerkship }\end{array}$ & $\begin{array}{l}\text { International } \\
\text { Elective }\end{array}$ & $\begin{array}{l}\text { International } \\
\text { Research } \\
\text { Internship }\end{array}$ \\
\hline $\begin{array}{l}\text { Medical Knowledge } \\
\text { (e.g. knowledge about syndromes, treatments, } \\
\text { drugs, diets) }\end{array}$ & + & + & - \\
\hline $\begin{array}{l}\text { Clinical Skills } \\
\text { (e.g. suturing and diagnostic skills, such as } \\
\text { differential diagnosis, physical examination, } \\
\text { ability to work with less/different diagnostic } \\
\text { means) }\end{array}$ & + & + & - \\
\hline $\begin{array}{l}\text { Communication Skills } \\
\text { (e.g. breaking bad news) }\end{array}$ & + & + & - \\
\hline $\begin{array}{l}\text { Intercultural Skills } \\
\text { (e.g. intercultural communication skills, sensi- } \\
\text { tivity to culturally determined presentation of } \\
\text { symptoms, sensitivity to context of patients, } \\
\text { reflection on cultural differences, language } \\
\text { skills) }\end{array}$ & + & + & - \\
\hline $\begin{array}{l}\text { Academic Development } \\
\text { (e.g. ability to conduct scientific research, } \\
\text { handle scientific knowledge, generic skills like } \\
\text { giving a presentation, general education, e.g. } \\
\text { ethical development) }\end{array}$ & - & - & + \\
\hline $\begin{array}{l}\text { Health Care in the host country } \\
\text { (e.g. health care organisation, hospital culture, } \\
\text { indigenous medicine, indigenous sick role, } \\
\text { reflection on the way healthcare works in } \\
\text { different settings, vision on development assis- } \\
\text { tance) }\end{array}$ & + & + & - \\
\hline $\begin{array}{l}\text { Knowledge about Society and Culture of the } \\
\text { host country } \\
\text { (e.g. culture, religion, poverty, inequity) }\end{array}$ & + & + & - \\
\hline $\begin{array}{l}\text { Personal Growth } \\
\text { (e.g. self-knowledge, self-efficacy, self man- } \\
\text { agement, widening of one's horizon, clarity } \\
\text { about preferences for specialisation, coping } \\
\text { with loneliness) }\end{array}$ & + & + & + \\
\hline $\begin{array}{l}\text { Professional Development } \\
\text { (e.g. ability to co-operate, flexibility in adapt- } \\
\text { ing to different circumstances, such as un- } \\
\text { known disease, very sick patients, little super- } \\
\text { vision) }\end{array}$ & + & + & + \\
\hline
\end{tabular}


Appendix 1 -continued-

\section{Aim of the framework of domains of learning outcomes}

The aim of the framework of domains of desired learning outcomes for Dutch undergraduate medical students is:

- To provide suggestions for learning objectives in advance of the international internship and to provide suggestions for evaluating them during or after the internship,

- The framework can be used by both students and supervisors,

- The framework follows the traditional knowledge / skills / attitudes distinction. Learning outcomes can be formulated in a 'competency like style', with integration of different domains.

\section{Things to keep in mind}

When using the framework for formulating learning outcomes one should keep in mind:

- Type of internship,

- Level of development of the host country (high/low),

- Study stage of student. 



\title{
Chapter 7
}

\section{Towards a Grounded Theory of Learning in International Internships ${ }^{1}$}

\begin{abstract}
Introduction: Globalisation has given internationalisation a place on the medical education agenda. Usually, internationalisation means outbound student mobility, especially in the form of international internships. The literature has paid little attention to student mobility or the educational effects of international internships. This study is aimed at providing a theory of learning in international internships by integrating empirical studies.

Methods: The reported study represents the phase of grounded theory research in which a 'core category' is identified and integrated with 'central categories' to construct a theory that is ready for testing by further research.

Participants and setting: The presented grounded theory is based on data from surveys of coordinators of internationalisation programmes and in-depth interviews with students at Dutch medical schools, interviews with supervisors at the sites of students' international internships, and a questionnaire administered to an international panel of experts on student mobility.

Results: The emerging 'core category' is 'sense of belonging'. Integrated with the 'central categories' of supervision, learning processes, and learning outcomes it provides an explanation of students' different learning outcomes. Experiential (unstructured) learning processes predominated. Students' learning was fostered by a 'sense of belonging' and hampered when this was weak, e.g. due to an unfavourable social climate.

Discussion and conclusions: The results suggest that active learning processes (self-directed or guided) improve the effectiveness of international internships.

\footnotetext{
${ }^{1}$ This chapter has been submitted as: Niemantsverdriet S, van der Vleuten CPM, Majoor GD \& Scherpbier AJJA. Towards a Grounded Theory of learning in International Internships.
} 
Structuring learning processes requires additional skills from both students and supervisors. The use of study guides as an instructional tool may enhance structure. Future research should focus on ways of improving students 'sense of belonging'.

\section{Introduction}

Globalisation is generally recognised as a factor that affects the health of populations and the delivery of health care all over the world. ${ }^{1,2}$ It is therefore important that medical education should pay attention to relevant globalisation issues. ${ }^{3,4}$ This can be done by internationalisation of education, which can take the form of internationalisation of the curriculum, student mobility and staff mobility. ${ }^{5}$ The most common approach to internationalisation in medical education today is student mobility, i.e. students going to another country for part of their training in international internships like clerkships or research electives. ${ }^{6,7}$

In the medical education literature international internships have not received a great deal of attention so far. Some publications have addressed the potential dangers of international internships, such as moral dilemmas ${ }^{8}$ and risks of infections. ${ }^{9,10}$ Thompson et al. $(2003)^{11}$ demonstrated, however, that learning from international internships needed further investigation. In their review of the scant literature on the educational effects of international internships, they found that the studies they reviewed examined for example only a limited number of variables. Because we wanted to present a completer picture, we chose a holistic and inductive approach to explore learning in international internships. We used a qualitative research method, grounded theory, because it is aimed at developing a theoretical explanation of social phenomena which is grounded in data from the field in question. Other qualitative approaches were considered to be less useful because they focus on understanding the essence of experiences about a phenomenon (phenomenology) or on describing and interpreting a cultural and social group (ethnography). ${ }^{12}$

The current study resembles the final phase of grounded theory research in which a set of concepts is integrated to provide a preliminary theoretical explanation of learning on international internships. ${ }^{13,14}$ 


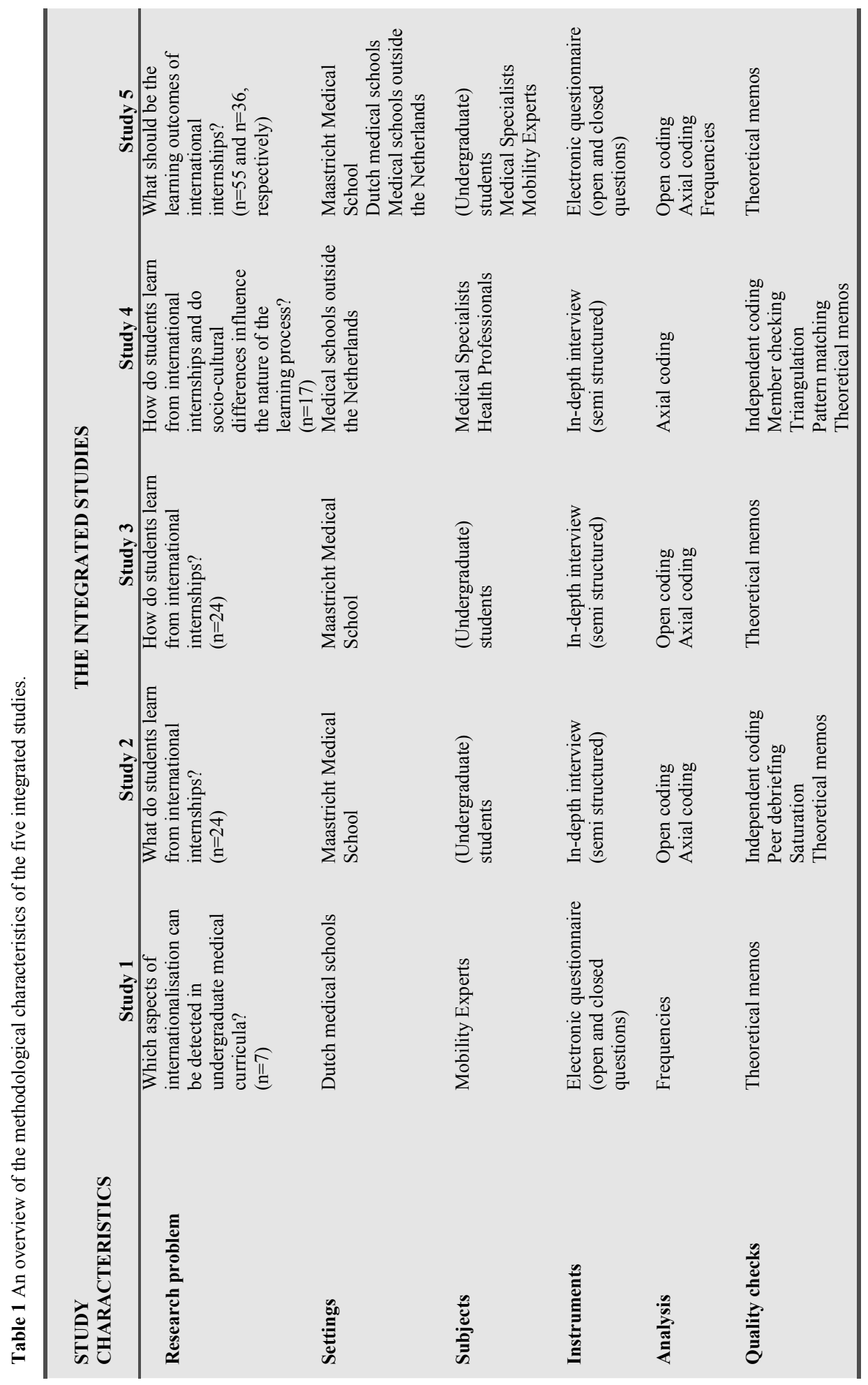




\section{Method}

\section{Research problem}

The grounded theory approach involves cycles of simultaneous data collection and analysis in which the results of the ongoing data analysis inform subsequent data collection. ${ }^{13,14}$ Table 1 presents an overview of the five studies that have been integrated in the present study and which research problems relating to learning in international internships were examined by the consecutive studies.

\section{Setting and subjects}

Table 1 shows that the first studies were conducted in medical schools in the Netherlands. These studies involved a survey of coordinators of internationalisation $^{7}$ and interviews with medical students. ${ }^{15,16}$ In a following study we interviewed foreign (local) supervisors of Dutch medical students during international internships. ${ }^{17}$ These interviews were conducted in departments of medical schools in Melbourne (University of Melbourne and Monash University), Sydney (University of New South Wales) and Broken Hill (Department of Rural Health, University of Sydney). Supervisors from the Philippines, Kenya and Mexico were selected from the participants of the 2003 'Network: TUFH' (Towards Unity for Health) conference in Australia and they were interviewed during the conference. In another study (table 1: study 5) international experts were recruited from medical schools in the Netherlands and universities outside the Netherlands (Mozambique, Canada, Ecuador, Australia, Philippines).

\section{Instruments}

Data collection in grounded theory is not restricted to specific modalities. ${ }^{13,14}$ In our studies we used electronic surveys and in-depth semi-structured interviews (table 1). The Australian supervisors were interviewed at their work sites. This format added the advantage of 'direct observation' as a context for data interpretation.

\section{Analysis}

The grounded theory approach starts with an exploration phase characterised by 'open coding' of the data to identify categories. A second level coding process, so-called 'axial coding', explores and defines the connections between the central categories. On a further level a 'core category' is identified which makes the other categories 'work'. In this final phase a grounded theory is elaborated. In the course of the grounded theory trajectory, the cycle of data collection- 
analysis-reflection is repeated in an iterative process. ${ }^{13,14}$ Table 1 gives an overview of the various phases that were part of the different studies.

In the study reported in this paper we identified one 'core category'. This 'core category' was integrated with the 'central categories' of the previous studies. In this way we constructed a grounded theory that was in line with the data we had collected. This resembles the final phase of the grounded theory approach. ${ }^{13,14}$

\section{Results}

We present a preliminary grounded theory concerning learning in international internships by focusing on the 'central categories' (learning processes, learning outcomes, supervision) and the 'core category' (sense of belonging). Figure 1 shows the integrated 'core' and 'central' categories of the grounded theory. The arrows indicate the direction of the relationships between the categories.

Boxes 1 and 2 show summaries of coded interviews with two students, Linda and Becky. They also show the fit of the data with the emerging grounded theory and the variability of students' learning in international internships, as explained by the grounded theory. The boxes serve as typical examples to illustrate the preliminary grounded theory.

\section{Learning processes (central category)}

The way learning processes were described by students and foreign supervisors ${ }^{16} 17$ closely matched the learning processes that are categorised in the educational literature as 'New Learning, ${ }^{18}$ In 'New learning' three types of learning processes can be distinguished: guided, experiential and self directed learning processes. These learning processes differ in the way the learning is structured. In 'guided learning', the teacher structures most of the learning functions (preparatory, executive and closing functions), whereas in 'self-directed learning', the student does so him/herself. In 'experiential learning', learning is an unstructured side effect of activities. ${ }^{19}$ The learning processes of most of the students in our studies appeared to match the experiential learning process. ${ }^{16,17}$ Box 1 outlines the self-directed and guided learning processes of a third-year medical student fictitiously named Becky; the coded learning functions (preparation, execution, closing) are given in brackets. Box 2 describes the experiential learning process of a third-year medical student fictitiously named Linda.

\section{Learning outcomes (central category)}

During the interviews the students described a wide range of learning outcomes. Some students reported that they had performed very advanced tasks, whereas others had had very limited (hands-on) learning experiences. What students did 
and learned proved to be unrelated to their year of study, type of elective or country visited. $^{15}$ The results suggest that students' learning processes may (at least partially) explain the differences between their learning outcomes. ${ }^{16}$ When the learning processes of most students match experiential learning (learning as an unstructured side effect of activities), learning outcomes are likely to be diverse and unpredictable. However, students who adopted more structured learning processes (self directed or guided learning) were found to be able to achieve their intended learning outcomes.

In a Delphi procedure the range of learning outcomes reported by the students was validated. This resulted in a framework of desired domains of learning outcomes (see: study 5 in table 1). A condensed version of this framework is shown in Figure 1.

\section{Supervision (central category)}

The information from the interviews with the supervisors about students' learning processes was largely consistent with findings from students' self reports. Students described their learning processes slightly more often as self directed processes. This was probably due to the definition of self-directed learning that we used. Self-directed learning was defined as learning that required active stimulation by supervisors. This means that some students may actually have had self-directed learning processes although not actively supported by their (external) supervisors. ${ }^{17}$

The observed differences between students in the quality of their learning outcomes may also be partly explained by experiences with incompetent and/or unwilling supervisors, which were reported by some students in connection with unfulfilled learning potential. ${ }^{15,16}$ Box 2 shows the relationship between Linda and her supervisors. Linda's supervisors did not pay much attention to her or her learning process. This resulted in an experiential (unstructured) learning process.

\section{Sense of 'belonging' (core category)}

Social cultural differences together with students' coping styles seemed to contribute to their sense of 'belonging' at the internship site. Findings from interviews with students and foreign supervisors suggest that more sociocultural differences were reported when the sociocultural difference between the elective site and the students' home country, in this case the Netherlands, was greater. Presumably, the greater the differences between national cultures, the greater the likelihood that productive learning was obstructed by such differences. ${ }^{16,17}$ Box 2 shows how sociocultural differences hampered Linda's learning process.

Despite the positive evaluation of their internships by the vast majority of the students, many also reported a variety of personal, cultural and political problems. Students also reported problems due to sickness (either of themselves or 
their supervisors), problems with their supervisor or problems due to the organisation of the internship programme. Coping style was found to be important in dealing adequately with these problems. ${ }^{15}$ Box 1 shows Becky's active coping behaviour by making her problems explicit and finding ways of dealing with them in the future. Box 2 shows Linda's avoiding coping strategy, which eventually resulted in her withdrawing from the problem area.

In cases where student and supervisor both acknowledged that there were differences and problems, they managed to work together and coped with these differences and problems. In cases where students felt the supervisor (or substitutes) was not really involved, students, depending on the students' coping style: coped successfully or avoided differences and problems, and even withdrew from differences and problems. Eventually, this could lead to withdrawal from the internship site (see Box 2).

The sense of 'belonging' at the international internship site seems similar to the concept of 'educational climate' or 'educational environment' of the clinical department in the hospital, as described by Hutchinson $(2003)^{20}$ and Dornan $(2006)^{21}$. These concepts describe how in clinical departments at home a positive social climate promotes involvement of students in practice and fosters their learning by 'supported participation' in the workplace environment. 
- Box 1 - Case of Becky; Self-directed and guided learning with strong 'sense of belonging'.

Becky undertook an orientation internship in Sweden in her third year. Before she went off, she contacted the gynaecologist in Sweden who was going to supervise her. She contacted the gynaecologist at the home university who was going to be her internal supervisor, as well. With the three of them they worked out a learning programme for the full six weeks of the internship. In addition they worked out a small research plan, which Becky would be able to complete within six weeks. She took a preliminary Swedish language course. [preparation]

During the six weeks of her internship in Sweden, Becky followed a rotation scheme of two weeks in the Delivery Room, the Operating theatre, and the Laboratory, respectively. The external supervisor was away on holiday for three weeks during the internship period, but he appointed others to look after her, which worked out quite well. During each of the three rotations she was supervised during all kinds of hands-on experience, such as holding babies just after delivery, suturing (even closing a womb after a Caesarean section), and examining chromosome material. Her basic Swedish improved during the six weeks, but she was happy that most of the times people helped her out by giving English translations. [execution] [sense of belonging]

She liked the Swedes very much; she saw them as somewhat more emancipated and a little less hierarchical than Dutch people. [sociocultural differences]

During the time of Becky's internship a fellow student of hers was on a internship in another department. In the evenings and weekends they spent a lot of time together. Helping each other to cope with their experiences in the hospital (like emotionally dealing with severely sick patients). Becky was left with the moral dilemma that as a third year student she had conducted examinations and activities which were above her status as third year student and of which patients were not always informed. She decided that in future clerkships she would be more assertive in asking that attention should be paid to those matters. [coping]

The evaluation of the internship was done together with her various Swedish supervisors, who filled out a form and gave verbal explanations. On her return to the Netherlands, Becky discussed her research report with her internal supervisor. With a number of additions the report was 'satisfactory'. Actually, the internal supervisor was pleasantly surprised by the findings of her research. [closing] 
- Box 2 - Case of Linda; experiential and guided learning with a weak 'sense of belonging'.

Linda undertook an orientation internship in Scotland, in her third year. At the time she was still living with her parents. The goal she had set herself for the international internship was to find out how she would cope without the support of her family. In addition, she wanted to experience what paediatrics was like. Together with three fellow students she decided to do an orientation internship in paediatrics in Scotland. She did not think that a great deal of preparation was necessary. She spoke with fellow students who had done the internship the year before. She did not prepare with respect to language because she was going to an English speaking country and she thought that language would not be a problem. She visited her internal supervisor before she left for Scotland. The supervisor gave them some instructions on writing a report about a patient while abroad. [preparation]

Linda and the other students saw their external supervisor (apparently from an Asian background) for less than 15 minutes each week. For the rest of the time the three Dutch students were assigned to different hospital departments. They were attached to different specialties, where sometimes they were the only student and sometimes they were part of groups of about five persons (nurses and students), who accompanied the specialists on their rounds or during consultations. She was afraid to speak up in the groups, because she was the only third year student. Her lack of basic medical knowledge meant that there were many times when she had no idea 'what the specialist was doing'. [execution]

In addition, she found herself faced with a rather hierarchical organisation, which made her hesitant to ask questions. [socio-cultural differences]

Because of the way the programme was organised, it seemed that no one missed her when she did not turn up. She attended mostly on the mornings and in the last week she did not attend at all. [sense of belonging] [coping]

On returning home she discussed her report with the internal supervisor. She received a 'good' mark, partly based on the evaluation of her external supervisor. She did not really feel that she had learned a great deal about Paediatrics. This was especially due to the language barrier between her and the Scottish health professionals and patients, whose language differed quite a lot from the English she was used to. It was not explained to her why her report received a lower mark than some of her fellow students' reports did (although the mark was quite high). Linda thought her internship was successful because she went to live on her own right after her return to the Netherlands. [closing] 


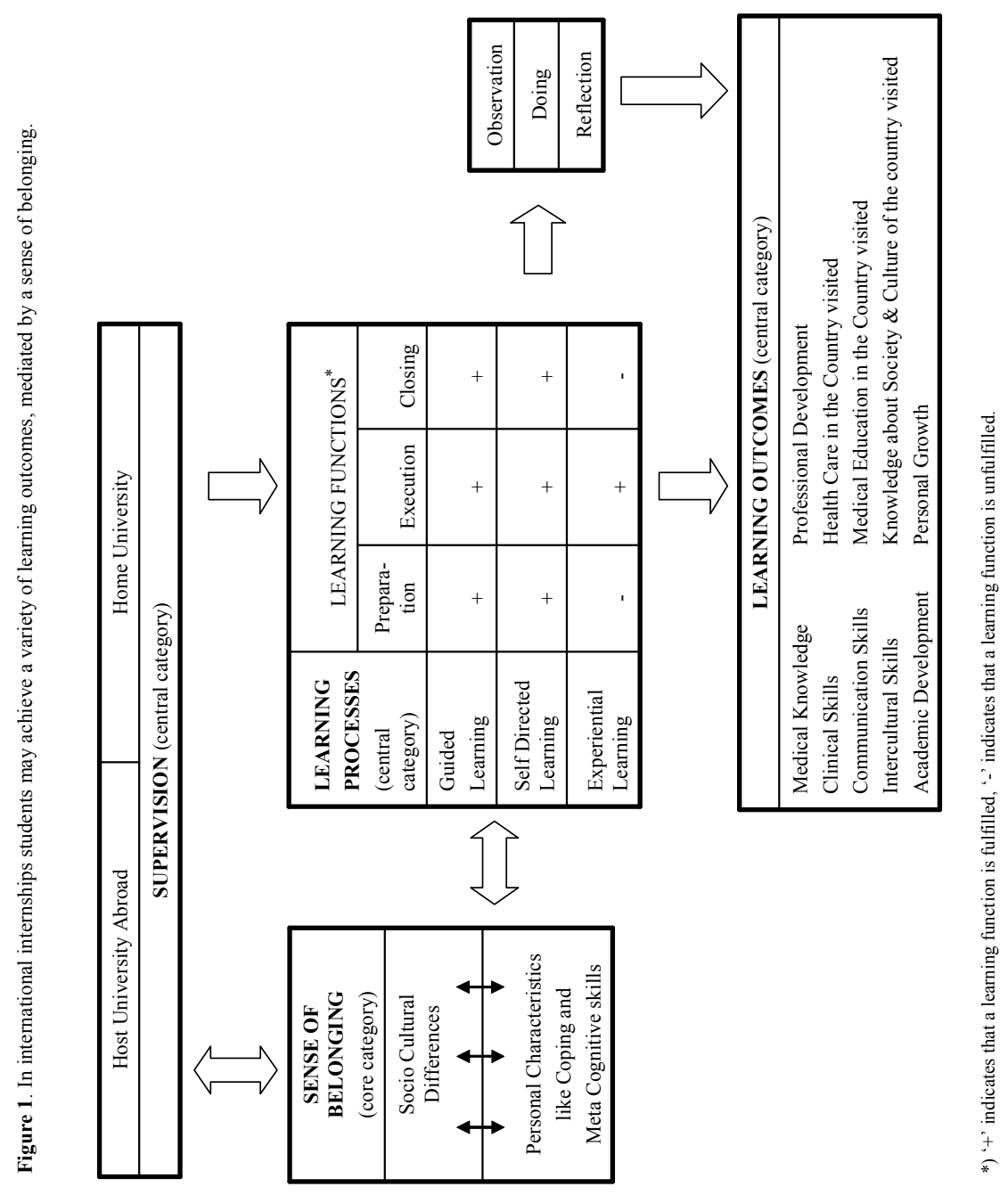




\section{Discussion and conclusion}

We have developed a grounded theory of learning in international internships. A 'core category' (sense of belonging) was identified and integrated with 'central categories' (supervision, learning outcomes, learning processes). The grounded theory serves to explain learning in international internships. We have tested this grounded theory against the data we have collected thus far. In order to add scope and go beyond the local context of the results, we have compared the categories of the theory to insights from the educational literature, such as 'Experience based learning' by Dornan $(2006)^{21}$. A final step in the development of the grounded theory would be to test it against newly collected data. ${ }^{13}$

The finding that the students whose learning processes were more active were more successful in achieving their learning outcomes suggests that these processes (guided or self-directed) in combination with unstructured learning processes, may be more effective. However, not all students are capable of designing their own learning processes and many will need support from supervisors to achieve self-directed learning. Strategies used by students to promote selfdirected learning include goal-directed learning, diagnostic learning and reflective learning. ${ }^{18}$ These strategies require process-oriented instruction. This means that supervisors should have the appropriate skills for facilitating self-directed learning. Findings from empirical studies have indicated how experienced (clinical) supervisors did not change abruptly from 'transmitters of content' to 'coaches of students' learning processes'. ${ }^{22,23}$

Another interesting as well as (cost) effective approach to structuring learning processes by making them more active (guided or self-directed) would be to develop the learning outcomes of the central category of 'learning outcomes' into 'task-based learning, ${ }^{24}$ In task-based learning a range of tasks undertaken by 'professionals' is identified. These tasks then become the focus for learning. Students are responsible for integrating their learning around these tasks; they are assisted in this process by study guides. These study guides could be made available as e-learning tools.

The sociocultural dimension of the learning processes on international internships may yield additional educational value. Thus, we recommend exploration of ways to transform sociocultural differences between students and supervisors from a potential barrier to learning into an integral part of student learning experiences. One way might be to ask students to prepare, elaborate and reflect on critical events relating to sociocultural differences between them and their supervisors, other healthcare professionals and patients. 
Future research should focus on the core category: 'sense of belonging' and how that could be improved. Students' characteristics, such as type of personality, metacognitive skills and motivation for undertaking an international internship, could be further investigated. Future research should also focus on preparation for and assessment of international internships and the role of the supervisor from the home institution therein. Finally, it would be worthwhile to quantitatively test the relationships presented in the preliminary grounded theory.

\section{References}

1. Unwin E, Alberti G, Aspray T, Edwards R, Mbanya J, Sobngwi, Mugusi F, Rashid S, Setel P, Whiting D. Economic globalisation and its effect on health. British Medical Journal 1998;316:1401-2.

2. Bateman C, Baker T, Hoornenborg E, Ericsson U. Bringing global issues to medical teaching. Lancet 2001;358:1539-42.

3. Edwards R, Rowson M, Piachaud J. Teaching international health issues to medical students. Medical Education 2001;35:807-8.

4. Eckhert NL. The global pipeline: too narrow, too wide or just right? Medical Education 2002;36:606-13.

5. Knight J. Monitoring the quality and progress of internationalisation. Journal of Studies International Education 2001;5:228-43.

6. Teichler U. Changes of ERASMUS: under the umbrella of SOCRATES. Journal of Studies International Education 2001:5;201-27.

7. Niemantsverdriet S, Majoor GD, Scherpbier AJJA, van der Vleuten CPM Internationalisation of medical education in the Netherlands: state of affairs. Medical Teacher, 2006a;28:187-89. [Study 1]

8. Banatvala N, Doyal L. Knowing when to say "no" on the student elective. British Medical Journal 1998;316:1404-05.

9. Wilkinson D, Symon B. Medical students, their electives, and HIV. British Medical Journal 1999;318:139-140.

10. Moss PJ \& Beeching NJ. Provision of health advice for UK medical students planning to travel overseas for their elective study period: questionnaire survey. British Medical Journal 1999;318:161-62.

11. Thompson MJ, Huntington MK, Hunt DD, Pinsky LE, Brodie JJ. Educational effects of international health electives on US and Canadian medical students and residents: A literature review. Academic Medicine 2003;78:342-7.

12. Creswell JW. Qualitative inquiry and Research Design: Choosing among Five traditions. Thousand Oaks, CA: Sage Publications, 1998.

13. Strauss A, Corbin J. Basics of Qualitative Research, Techniques and Procedures for Developing Grounded Theory, Second Edition, Newbury Park: Sage Publications, 1998.

14. Kennedy TJT, Lingard LA. (2006) Making sense of grounded theory in medical education. Medical Education 2006;40:101-08.

15. Niemantsverdriet S, Majoor GD, Scherpbier AJJA, van der Vleuten CPM. I found myself a down-to-earth Dutch girl: a qualitative study into learning outcomes from internships abroad. Medical Education 2004;38:749-57. [Study 2] 
16. Niemantsverdriet S, van der Vleuten CPM, Majoor GD, Scherpbier AJJA. An explorative study into learning on international internships; experiential learning processes dominate. Medical Education 2005;39:1236-42. [Study 3]

17. Niemantsverdriet S, van der Vleuten CPM, Majoor GD, Scherpbier AJJA. The learning processes of international students through the eyes of foreign supervisors. Medical Teacher 2006b;28:e104-e111. [Study 4]

18. Simons PRJ, van der Linden J, Duffy T. New learning: three ways to learn in a new balance. In Simons PRJ, van der Linden J, Duffy T. (Eds), New Learning (pp 1-20). Dordrecht: Kluwer Academic Publishers, 2000.

19. Van Hout-Wolters B, Simons PRJ, Volet S. (2000). Active learning: self-directed learning and independent work. In Simons PRJ, van der Linden J, Duffy T. (Eds) New Learning (pp 21-36). Dordrecht: Kluwer Academic Publishers, 2000.

20. Hutchinson L. Educational environment. In Cantillon P, Hutchinson L, Wood D. (Eds) ABC of teaching and learning in medicine (pp 39-41). London: British Medical Journal Publishing group, 2003.

21. Dornan T. Experience based learning. Learning clinical medicine in workplaces. Maastricht: PhD Thesis, 2006.

22. Hoogveld AWM, Paas F, Jochems WMG \& van Merriënboer JJG. Exploring teachers' instructional design practices from a systems design perspective. Instructional Science, 2002;30:291305.

23. Dornan T, Scherpbier A, King N, Boshuizen H. Clinical teachers and problem-based learning: A phenomenological study. Medical Education 2005(a);39:163-70.

24. Dornan T, Hadfield J, Brown M, Boshuizen H, Scherpbier AJJA. How can medical students learn in a self-directed way in the clinical environment? Design-based research. Medical Education 2005(b);39:356-64. 



\section{Chapter 8}

\section{Conclusion and Discussion}

In this chapter the conclusions of the research are summarised and discussed. The practical implications of the conclusions are presented and recommendations are made for future research. At the end of the chapter the limitations of the research are stated.

\section{General Conclusion and Discussion}

The aim of the research described in this thesis was to find answers to the general research question: What are the educational effects of internationalisation of education for learning in the undergraduate medical curriculum? The answer to this question that resulted from our research is based on a synthesis of the answers to the specific research questions that emerged as the research progressed.

Research question 1: 'Which aspects of internationalisation are present in the curricula of the Dutch medical schools?' All the curricula were found to comprise some of the features of internationalisation, such as courses in English, topics related to (imported) tropical diseases, topics related to international health care systems, and facilities for foreign language training. International programmes were frequently offered as electives. Four of the eight medical schools offered no educational component that formally prepared students for encounters with patients from different cultural backgrounds. In today's multicultural society this has to be considered a curricular shortcoming, also in relation to those students who do not undertake international educational activities. In all the medical schools, the numbers of students participating in outward mobility exceeded the numbers of students involved in inward mobility. 
The second research question arose from the first study, which showed that internationalisation most commonly took the form of outward mobility of students. Therefore we decided to focus our explorations on the learning of students who went abroad for part of their training. We formulated research question 2: 'What do undergraduate medical students learn from international internships?' Students reported a broad range of learning outcomes. International internships appeared to be suitable for meeting objectives of medical education. However, students reported a broad range of problems too, such as culture shock, moral dilemmas, sickness, and problems with supervisors. In part these problems resemble problems encountered by students during clerkships at home. However, the fact that during international internships students are far away from home without recourse to their usual sources of support may aggravate problems and make it harder for students to resolve them. It appeared that the coping style used by the students was an important determinant of the extent to which students were able to deal adequately with their problems.

Another interesting finding was that the different learning outcomes were not equally distributed among the students. It was remarkable that neither year of study, type of internship, nor the country visited appeared to account for the differences between students in the quality and nature of their learning outcomes.

In the next study we further explored the differences between students' learning outcomes. Our earlier findings seemed to rule out factors related to aspects of the learning environment, such as year of study, type of internship, country visited. We presumed that factors related to the learning process might shed more light on this issue. Thus we formulated research question 3: 'What is the nature of the learning process that takes place when undergraduate medical students undertake international internships?' We used a study design that enabled triangulation of the findings, i.e. we interviewed both the students and their foreign supervisors.

The findings from the interviews could be related to the educational theory of learning processes referred to as "new learning". In "new learning" three types of learning processes are distinguished: 'guided learning', 'self-directed learning' and 'experiential learning,. 1,2 In guided learning the supervisor prescribes the learning activities, i.e. preparation, execution, and evaluation. With selfdirected learning, it is the student who controls the learning activities. In experiential learning, learning occurs as a by-product of (other) activities. The way the students in our study learned during international internships is best classified as experiential learning. Only in a small minority of cases could the learning be characterised as guided learning or self-directed learning.

The predominance of experiential learning processes might explain the differences between students' learning outcomes. With unstructured learning proc- 
esses, which are characteristic of experiential learning, any learning outcome is possible. Students whose learning processes showed more structure appeared to be better able to achieve their intended outcomes.

Our categorisation of learning processes appeared to be more in line with the descriptions proposed by Simons et al. (2000) $)^{1}$ than with Kolb's well-known description of experiential learning (1984), ${ }^{3}$ because of the prominence of unintentional learning processes observed in our research. Generally, four global categories of workplace learning are distinguished: learning by experiencing; learning by social interaction; learning by elaborating theory; learning by reflection. ${ }^{4}$ Ideally, these types of learning interact with each other, although this does not always happen automatically. Learning by experience and social interaction are basic ways of learning, to which learners may be exposed unintentionally and unconsciously. This implies that learning by experience and social interaction does not necessarily lead to reflection and/or theoretical elaboration ${ }^{5}$; as seems to be suggested by Kolb's (1984) ${ }^{3}$ spiral model of 'experiential learning' as an ongoing iterative process. The majority of our findings were more consistent with unintentional and unconscious learning, which is why we think our data shows a better fit with the ideas of Simons et al. (2000) ${ }^{1}$ and Van HoutWolters et al. $(2000)^{2}$.

Another salient finding that emerged from the interviews with the students is that in some cases socio-cultural differences between student and supervisor stood in the way of fruitful learning. We could relate these findings to descriptions in the educational literature of 'socio-cultural mismatch in students' and supervisors' experiential interface'. ${ }^{6}$ In order to examine this concept further we formulated research question 4: 'Do socio-cultural differences influence the nature of the learning processes that take place when students undertake international internships?' This question was included in the interviews with the foreign supervisors.

The interviews with the supervisors yielded similar findings to those resulting from the interviews with the students. It became clear that productive learning could be difficult to achieve, especially when differences between the national cultures of the host country and the student's home country were extensive. To identify differences between cultures we relied on Hofstede's work (1986) ${ }^{7}$ and $(1996)^{8}$.

Next we examined the idea that better structuring of students' learning processes would improve the educational effectiveness of international internships. This idea was rooted in our finding that unstructured experiential learning processes dominated the internships. A balance between structured and unstructured learning processes has been advocated. ${ }^{1}$ Defining learning outcomes is the first step towards better structured learning processes. ${ }^{9}$ This line of argument led to research question 5: 'What should be the learning outcomes of international in- 
ternships for undergraduate medical students?' We put this question to stakeholders in the field of internationalisation of undergraduate medical education. With the help of their expert views we refined and validated the framework that we had developed earlier to answer research question 2 . This resulted in a framework of desired learning outcomes for international internships, containing the domains: Medical Knowledge, Clinical Skills, Communication Skills, Intercultural Skills, Academic Development, Health Care in the country visited, Knowledge about Society and Culture of the country visited, Personal Growth and Professional Development.

The aim of the final study of this thesis was: 'To integrate a set of concepts into a theoretical explanation for learning during international internships.' The findings of the studies conducted up to this point were synthesised in a preliminary Grounded Theory that clarified the learning of undergraduate medical students during international internships. Formulating a preliminary Grounded Theory is the phase of Grounded Theory methodology that immediately precedes the formulation of a definitive theory. Our preliminary theory consisted of a 'core category' ('sense of belonging') integrated with the 'central categories' of supervision, learning processes, and learning outcomes, which together accounted for the variance in students' learning.

With regard to the general research question we conclude that international internships offer a potentially powerful learning environment where students can acquire new knowledge, skills, and attitudes in the context of authentic complex task situations. The broad range of learning outcomes reported by students consisted of desired outcomes of medical education. However, it seems possible to make learning in international internships more effective. The key to improvement appears to be fostering students' 'sense of belonging' at the internship site. To improve the 'sense of belonging' we recommend striving for equilibrium in learning processes. Instead of mainly experiential learning processes, international internships should include self-directed and guided learning processes as well. To counterbalance the prevailing unstructured experiential learning processes, we advocate that students' learning during international internships should be structured in such a way that active learning is promoted. This balance between experiential and active learning has also been recommended in educational theory. ${ }^{1}$ Findings of an empirical study of learning in (clinical) practice also led to recommendation of more structure in students' learning in practice, as is reflected by the central concept of 'supported participation'. ${ }^{10}$ Furthermore, we recommend that attention should be given to students' personal coping styles and to the intercultural competence of students (and staff) because this might enhance students' 'sense of belonging' at international internship sites. 
In this thesis we mainly concentrated on the learning of students who went abroad for internships. As a consequence, we are only able to provide a partial answer to the general research question. A more comprehensive answer would require studying 'Internationalisation at Home' ${ }^{10,11}$ as well, including inward mobility of students (see also recommendations for future research).

\section{Improving the 'sense of belonging'}

The 'sense of belonging' that students experience at international internship sites was identified as the core category of the preliminary Grounded Theory (chapter 7). Sense of belonging seems to resemble the concept of 'educational climate' in clinical departments (at home). ${ }^{10,13}$ The key to increased effectiveness of learning during international internships appears to be improvement of the 'sense of belonging'. We will discuss some recommendations for steps to achieve this: fostering self-directed learning, independent work, 'good old' guided learning and training in the use of coping styles.

\section{Advancing Self-directed Learning}

Students' learning processes can be better structured by promoting self-directed learning. Nowadays self-directed learning is an important goal in higher education, because it is expected to contribute to active, meaningful (as opposed to rote) and lifelong learning. However, self-directed learning requires all kinds of (meta-cognitive) skills, such as goal setting, selecting learning resources, time management, reflective skills and diagnostic skills. It is therefore not surprising that not all students are capable of designing their own learning processes in a self-directed way. Many students need support from their supervisors to become effective self-directed learners. ${ }^{1,14}$

To help students develop skills for self-directed learning, supervisors should provide instruction that is oriented to the learning process. Some studies have shown that experienced (clinical) supervisors did not change all at once from 'transmitters of content' to 'coaches of students' learning processes'. ${ }^{15,16}$ Supervisors will need to develop skills for facilitating self-directed learning. This means that enhancing self-directed learning in students requires professional development of supervisors in this area.

In our opinion promoting students' self-directed learning during international internships should be the responsibility of the supervisors at the students' home university. Training foreign supervisors for this role would inevitably create organisational and financial problems. More importantly, it would be like throwing the baby out with the bath water, for students undertake international internships to gain 'different' learning experiences. 


\section{Using Independent Work}

Students' learning processes during international internships can also be structured by requiring students to do 'independent work', which is another form of active learning. 'Independent work' is characterised by asking students to work independently on assignments, of which, for example, the goals and kinds of activities, control and regulation as well as feedback are controlled by the supervisor. $^{2}$

'Independent work' could be organised in accordance with the framework of desired learning outcomes which we developed in a Delphi procedure in Chapter 6. In the framework, learning outcomes are formulated as isolated domains of knowledge, skills, and attitudes and they could be translated into assignments with an integrated, competency-like character.

An aid to competency formulation is the work of Stoof et al. (2002). ${ }^{17}$ Stoof et al. (2002). ${ }^{17}$ presented a 'boundary approach' as an aid to competency formulation. The 'boundary approach' emphasises the viability of competence: the proven adequacy of the context where it is used. An inspiring attempt to a substantial construction of 'intercultural competence' was made by Deardorff $(2006)^{18}$. In a Delphi-procedure consensus was reached on 22 essential elements of 'intercultural competence', such as flexibility, mindfulness, withholding judgement, and respect for other cultures.

A framework of competencies (for desired learning outcomes) might be used as a study guide, which students can take with them to their international internship sites. Alternatively, study guides could be made available via the Internet. ${ }^{19}$ An educational tool very similar to the type of study guide we propose, was developed by Dornan et al. $(2005 b)^{20}$ to structure learning during regular clerkship rotations (in the clinic at home). It was called task-based learning, which involved identifying a range of tasks undertaken by 'a professional', which students could use as the focus for their learning.

\section{Enhancing 'Good Old’ Guided Learning}

Naturally, guided learning can always be relied on to structure students' learning processes. In guided learning, the supervisor controls the learning functions: preparation, execution and evaluation. ${ }^{1,2}$ In our opinion, 'socio-cultural differences' is a topic that should be addressed in the curriculum and for which a guided learning approach would be suitable. As we argued in chapter 2, it should be considered a shortcoming that some medical schools offer no training to prepare students for contacts with patients with different cultural backgrounds. Moreover, in chapter 5 we suggested that socio-cultural differences between students and their foreign supervisors should be transformed from a potential barrier to learning to an integral part of students' learning experiences. 
In an instructive workshop by Logghe \& Suurmond at the 2005 NVMO (Dutch Association for Medical Education) conference, it was argued that the best way to implement 'Interculturalisation' of medical education would be to ensure that it is embedded in the organisation as a whole, ${ }^{21}$ i.e. in the medical schools' policy, research, educational activities, and in the curriculum. During this workshop inspiring video instruction material was shown which would be very appropriate for training in skills laboratories.

\section{Training Coping Styles}

Students' coping styles ${ }^{22,23}$ were shown to be important in learning in international internships. As we suggested in chapter 2, problems may seem more serious when one is far away from home and one's usual support network. Students might be helped by short courses that give them more insight into their own coping styles and introduce them to different constructive ways of handling problems. Of course, such courses would not have to be exclusively for students going abroad to do an internship.

\section{Recommendations for Future Research}

Future research might address the implementation and subsequent evaluation of all of the afore-mentioned recommendations to improve students' 'sense of belonging' at international internship sites.

Another research topic with regard to internationalisation of education might be assessment of students during international internships. The research showed that assessment of students' learning in international internships was rather arbitrary and accidental, depending on the (foreign) supervisors and the students themselves (chapters 4 \& 5). In general, students' attitudes towards learning are influenced by the assessment programme. Assessment programmes should be in line with the recommended student-centred learning processes and authentic task situations. ${ }^{24-26}$ Therefore it would be interesting to examine the use of portfolio in international internship assessment. Additionally, it would be interesting to examine the contribution of international internship assessment to educational quality assurance.

Because early in the research we decided to focus on the outward mobility of students, we were able to answer only a part of the general research question. To fully answer our general research question, it would be interesting to study 'Internationalisation at Home' as well, including inward mobility. The concept of 'Internationalisation at Home' functions as a new paradigm in the discourse about internationalisation. 'Internationalisation at Home' moves beyond (outbound) mobility and has a strong emphasis on teaching and learning in culturally 
diverse settings, which can also include the home university. ${ }^{112}$ The (traditional) view of internationalisation is challenged by questions like: What is done for international and intercultural dimensions in the work of faculty and administrative staff not involved in mobility? What is done for students who do not study abroad? What about diversity issues and access to international education? What are the educational effects of the international classroom? ${ }^{27}$ Given the implementation of Bachelor/Master programmes in medical education, it would be interesting to find out about the educational effects of these programmes.

\section{Limitations}

Grounded Theory methodology has been the guideline of the research reported in this thesis. It was a useful tool to guide us through the exploration and explanation of the social phenomenon of learning in international internships. It was an inspiring method which offered helpful directions for progressing through the different research stages.

However, the last stage we reached with our research was the preliminary Grounded Theory which we formulated on the basis of the results so far. As the qualification 'preliminary' indicates, this is not the actual final phase of the Grounded Theory trajectory. Proper completion of it would require testing our findings in a representative sample of different stakeholders in diverse national and cultural contexts.

Although we did our best to include all the stakeholders in the field in our studies and despite several quality checks, the conclusions based on the small-scale studies we conducted remain to be verified in a larger study.

\section{References}

1. Simons PRJ, van der Linden J, Duffy T. New learning: three ways to learn in a new balance. In Simons PRJ, van der Linden J, Duffy T. (Eds), New Learning (pp 1-20). Dordrecht: Kluwer Academic Publishers, 2000.

2. Van Hout-Wolters B, Simons PRJ, Volet S. (2000). Active learning: self-directed learning and independent work. In Simons PRJ, van der Linden J, Duffy T. (Eds) New Learning (pp 21-36). Dordrecht: Kluwer Academic Publishers, 2000.

3. Kolb DA. Experiential learning. Englewood Cliffs: Prentice-Hall, 1984.

4. Bolhuis $\mathrm{S} \&$ Doornbos A. Leren op de werkplek. (Workplace learning.) Zoetermeer: Ministerie van OC\&W, 2000.

5. Bolhuis S. Leren en veranderen bij volwassenen. Een nieuwe benadering. (Learning and change with adults. A new approach.) Bussum: Coutinhou, 2001.

6. Volet SE. (2001) Learning and motivation in context: A multi-dimensional and multi-level cognitive-situative perspective. In: Volet, S.E., Järvelä, S. (Eds) Motivation in learning contexts: Theoretical advances and methodological implications. London: Elsevier. 
7. Hofstede G. (1986) Cultural differences in teaching and learning, International Journal of Intercultural Relations, 10, p. 301.

8. Hofstede G. (1996) Difference and danger: cultural profiles of nations and limits to tolerance, Higher Education in Europe, XXI, p. 73.

9. Harden RM, Laidlaw JM, Ker JS, \& Mitchell HE. (1996) AMEE Medical Education Guide No. 7. Task-based learning: an educational strategy for undergraduate, postgraduate and continuing medical education, Part 2. Medical Teacher, 18, pp. 91-98.

10. Dornan T. Experience based learning. Learning clinical medicine in workplaces. Maastricht: Datawyse, 2006, PhD Thesis.

11. Wächter B. An introduction: Internationalization at Home in context, Journal of Studies in International Education, 2003;7:5.

12. Wächter B, Internationalisation at home - the context. In: Crowther P, Joris M, Otten M, Nilsson B, Teekens H, Wächter B. Internationalisation at Home: A Position Paper. Retrieved from: http://www.Nuffic.nl/netwerk/IAH-Booklet.pdf, 2005.

13. Hutchinson L. Educational environment. In Cantillon P, Hutchinson L, Wood D. (Eds) ABC of teaching and learning in medicine (pp 39-41). London: BMJ Publishing group, 2003.

14. Van Eekelen IM, Boshuizen HPA, Vermunt JD. Self-regulation in higher education teacher learning. Higher Education 2005;50:447-471.

15. Hoogveld, AWM, Paas F, Jochems WMG, Van Merriënboer JJG. (2002) Exploring teachers' instructional design practices from a systems design perspective. Instructional Science, 2002;30:291-305.

16. Dornan T, Scherpbier A, King N, Boshuizen H. Clinical teachers and problem-based learning: A phenomenological study. Medical Education 2005(a);39:163-70.

17. Stoof A, Martens RL, Van Merriëboer JJG, Bastiaens TJ. The Boundary approach of competence: a constructivist aid for understanding and using the concept of competence. Human Resource Development Review 2002;1:345-365.

18. Deardorff DK. Identification and assessment of intercultural competence as a student outcome of internationalisation. Journal of Studies in International Education, 10 (3) 241-266.

19. Van Merriënboer JJG. ID for competency-based learning: new directions for design, delivery and diagnosis. Interactive Educational Multimedia 2001;3:12-26.

20. Dornan T, Hadfield J, Brown M, Boshuizen H, Scherpbier AJJA. How can medical students learn in a self-directed way in the clinical environment? Design-based research. Medical Education 2005(b);39:356-64.

21. Logghe K, Suurmond J. Workshop interculturalisatie van het medisch onderwijs. (Workshop interculturalisation of medical education.) Egmond aan Zee: NVMO (Dutch Society for Medical Education), 2005.

22. Lazarus RS, Folkman S. Stress appraisal and coping. New York: Springer, 1984.

23. Compas BE, Connor-Smith JK, Saltzman H, Harding Thomsen A, Wadsworth ME. Coping with stress during Childhood and Adolescence: problems, progress, and potential in theory and research. Psychological Bulletin 2001;127:87-127.

24. Biggs JB Enhancing learning through constructive alignment. Higher Education 1996;32:347364.

25. Driessen E, Van der Vleuten CPM. Matching student assessment to problem-based learning: lessons from experience in a law faculty. Studies in Continuing Education, 2000;22:235-249.

26. Elshout-Mohr M, Oostdam F, Overmaat M. Student assessment within the context of constructivist educational settings. Studies in Educational Evaluation 2002;28:369-390.

27. Otten M. (2003) Intercultural learning and diversity in Higher Education, Journal of Studies in International Education, 7, p. 12. 
Chapter 8

28. Teekens H. Internationalization at Home: a background paper. International conference, 9-10 May 2005, Rotterdam, the Netherlands: Nuffic. Retrieved from: www.Nuffic.nl/pdf/netwerk/Background-paper-iah.pdf, 2005. 


\section{Summary}

\section{Chapter 1: Introduction}

In the framework of historical and political developments like globalisation, the unification of Europe and the Bologna process, medical educationalist started to take notice of Internationalisation of education. In the medical educational literature not much was published about internationalisation of education, however. The scarce published literature prohibited firm conclusions about learning in international internships, due to the methodological limitations of these reviewed studies. It was also not clear how and if current educational theories on learning in (the clinical) workplace could be applied to internationalisation of medical education. Hence we formulated a broad general research question: 'What are the educational effects of internationalisation of education for learning in the undergraduate curriculum in Medicine?'

To answer this general research question, more specific research questions were formulated. These specific research questions were based on the findings of our subsequent studies, which together form this thesis. The specific research questions were:

- Which aspects of internationalization can be detected in the Dutch undergraduate medical curricula?

- What do medical undergraduate students learn from international internships?

- What is the nature of the learning process that takes place when undergraduate medical students undertake international internships?

- Do socio-cultural differences influence the nature of the learning processes that takes place when undergraduate medical students undertake international internships?

- What should be learning outcomes of international internships for undergraduate medical students?

The nature of the study methodology could be characterised as Grounded Theory. 


\section{Chapter 2: State of Affairs}

This chapter reports a study which maps the state of affairs of internationalisation in the Dutch medical schools. Research questions were: 1. Which aspects of internationalisation can be detected in the Dutch undergraduate medical curricula? 2. What is the quantity and nature of student mobility at Dutch medical schools? 3.How is the quality of study programs abroad maintained?

An electronic questionnaire was filled out by 7 (out of 8 ) internationalisation coordinators of the Dutch medical schools. It turned out that all schools concentrate on some characteristics of internationalisation in their curriculum, although in many cases as electives. The number of outwards directed mobility exceeds the number of inwards directed mobility and all schools apply certain methods to ensure the quality of international internships. In four of the medical schools there was no training directed at dealing with patients from different sociocultural backgrounds, which we consider as a serious shortcoming. The findings of this study may be taken as representative for the Dutch situation.

\section{Chapter 3: What do students learn?}

In this study self-reports of students about their learning experiences from international internships were presented. In-depth interviews with 24 undergraduate students from Maastricht Medical School, who experienced at least one internship abroad, were conducted. Data were collected and analysed by a constant comparative method matching the 'open coding' and 'axial coding' phase of Grounded Theory methodology. Three types of internships were described by the students: orientation electives, research internships, elective/regular clerkships. Further a broad range of learning outcomes was described and a broad range of problems that students encountered during their internship was reported. These were: cultural problems, problems due to politics, problems with changes in the internship programme, problems with supervision, problems due to sickness of the supervisor or the student, and personal problems. Personal coping styles of students appeared to be important in dealing with these problems. Furthermore it seemed that students going for internships abroad are a special, internationally oriented group (among medical students). For example 17 out of 24 interviewees appeared to have prior international experience.

The unequal spread of learning outcomes over the students could not be explained by year of study, type of internship or the country visited. 


\section{Chapter 4: Students' perceptions of their learning processes}

In this study we hypothesised that the differences in the quantity and nature of learning outcomes of international internships between students, could be explained by the learning processes of the students. Therefore we again scrutinized the rich in-depth interview materials from the 24 undergraduate medical students of Maastricht Medical School (from our study described in chapter 3). The analysis resulted in 6 categories related to the learning processes: motivation, preparation, internal supervisor (home university), external supervisor (abroad), assessment, and positive (e.g. practising medical skills) and negative incidents (e.g. confrontation with corruption and slack behaviour towards and within health care) related to learning experiences. Our findings matched the learning processes described in the educational literature under 'New learning'. In 'New learning' three types of learning processes are described: 'guided learning', 'self-directed learning' and 'experiential learning'. In 'guided learning' the learning functions (or learning activities) preparation, execution and evaluation are controlled by a supervisor. In 'self-directed learning' the learning functions are controlled by the student. In 'experiential learning' there is no control over learning functions, learning occurs as by-product of other activities.

The learning process of the vast majority of the interviewed students matched 'experiential learning'. The unstructured character of 'experiential learning' seemed to explain the variance of learning outcomes between students, because these unstructured learning processes could lead to just any learning outcome.

Some students reported they were dissatisfied with their external supervisor or had mixed feelings about their supervision. We interpreted these experiences (at least for a part) as a mismatch in students and supervisor experiential interfaces, which are of course coloured by socio-cultural contexts (e.g. knowing that refusing a request is regarded as highly impolite in some cultures, may help to resolve mismatches).

\section{Chapter 5: Foreign supervisors' perceptions of students' learning processes}

In this study two research questions were dealt with: 1. What is the nature of undergraduate medical students' learning processes in international internships? 2.Are socio-cultural differences experienced during international internships? In fact this was a triangulation of our findings in a previous study (described in Chapter 4). Now we used another source for semi-structured interviews; instead of students we interviewed their foreign supervisors.

A multiple case-study, replication design was set up. The replication of the cases was focussed on the socio-cultural differences within the context of the intern- 
ship sites. Case 1 encompassed internships in the Outback of Australia $(\mathrm{n}=10)$; Case 2 encompassed internships in urban areas in Australia ( $n=3)$; Case 3 encompassed internships in Non-Western countries (Kenya, Mexico, Philippines) $(n=4)$.

The results of this study were largely consistent with the findings of the previous study with students: the learning processes of students' were dominantly described as 'experiential learning processes' and the greater the differences in national cultures between students and supervisors, the higher the number of socio-cultural differences reported by supervisors. These socio-cultural differences presumably were standing in the way of productive learning.

Based on the findings in this study it is advocated to explore ways to transform sociocultural differences from a potential barrier into a positive part of students' learning experiences. Besides it is advocated to stimulate 'self-directed' and 'guided learning processes', in addition to 'experiential learning' in international internships. In that way students could have more active, structured learning processes (leading to desired outcomes).

Of course the firmness of the conclusions in this study is limited by the small numbers studied and a potential effect of social desirability in the interviews with the supervisors.

\section{Chapter 6: What should be learning outcomes?}

To add structure to learning processes (to stimulate 'self-directed' and 'guided learning processes') a minimal requirement is to have defined learning outcomes. To establish desired learning outcomes of learning in international internships a Delphi procedure with an international panel of experts was conducted. Stability was attained in two rounds (round $1 n=55$; round $2 n=36$ ).

A framework of learning outcomes developed in a previous study (to categorize learning outcomes of international internships reported by students; see: chapter 3 ) was used as a starting point. With the advice of the panel of experts, it was developed further and validated into a framework of desired outcomes of international internships for Dutch undergraduate medical students. The framework encloses the domains: medical knowledge; clinical skills; communication skills; intercultural skills; academic development; health care in the country visited; knowledge about society and culture of the country visited; personal growth and professional development.

It was recommended to use the framework of domains by both students and supervisors to formulate learning outcomes, keeping in mind the type of internship, the level of development of the country visited and the study stage of the student. The framework was build according to the conventional subdivision of 
knowledge, skills and attitudes. It was recommended to convert these isolated domains into integrated competencies.

Although the panel of experts consisted of an impressive group of people, it is not sure that we have been able to include all relevant experts in the field. For example we could not motivate a group of mobility researchers to take place in our panel. Moreover the presented framework of desired learning outcomes applies to Dutch undergraduate medical students. The findings should be tested for other national cultures.

\section{Chapter 7: A preliminary Grounded Theory}

In this study findings of five empirical studies were integrated. These five studies all explored aspects of learning in international internships. They were conducted in the framework of this thesis and they were all described in detail in the former chapters. Together they form a preliminary grounded theory on learning in international internships by undergraduate medical students. The integration of these studies resembles the final phase of Grounded Theory methodology. A 'core category' (sense of belonging) was determined and integrated with the 'central categories' (supervision, learning processes, learning outcomes). Through the 'core category' (sense of belonging) it was shown how a positive social climate promoted involvement of students in practice and fostered their learning. At the same time a weak sense of belonging troubled the students' learning process and subsequent learning outcomes.

Based on the preliminary Grounded Theory it was recommended to improve students' sense of belonging at the internship site by adding more structure to their learning processes, which will require additional (meta-cognitive) skills from both students and supervisors. Another way to improve students' sense of belonging to the internship site by adding structure to students learning processes may be the implementation of study guides.

The study resembles the last phase of Grounded Theory methodology. To round it off the preliminary Grounded Theory should have to be tested against new collected data.

\section{Chapter 8: Conclusion and Discussion}

In this chapter the main conclusions are discussed. Subsequently recommendations for practice and future research are presented. The chapter is concluded with some remarks on the limitations of the studies which together form this thesis. 
In this thesis we sought to find an answer to the general research question: 'What are the educational effects of internationalisation of education for learning in the undergraduate curriculum in Medicine?'

Our answer to the general research question is: we conclude that learning in international internships is potentially learning in a powerful learning environment where students may acquire new knowledge and skills and attitudes in the context of authentic complex task situations. The broad range of learning outcomes which students reported comprised desired outcomes of medical education.

We recommend making learning in international internships altogether even more instructive by improvement of students' 'sense of belonging' at the internship site. To achieve this, we recommend adding structure to students' learning processes by: advancing self-directed learning, using independent work and enhancing guided learning. Finally we recommend improving personal characteristics of students' by training their coping styles.

Future research could evaluate all of the above mentioned recommendations for practice. Besides, future research could be directed at the assessment of students in international internship. It would also be interesting to explore how assessments of students could be used in quality care.

We are sorry to say that by concentrating on international internships we could only answer a part of the general research question. Therefore we also recommend future research to focus on 'Internationalisation at Home', including inwards-directed student mobility.

In spite of our efforts to check the quality of the study methodology and findings, a limitation of the conclusions presented is: the conclusions were based on small-scale studies and should be tested in representative samples of diverse national cultural contexts. 


\section{Samenvatting}

\section{Chapter 1: Introduction}

In het kielzog van historische en politieke ontwikkelingen, zoals globalisering, Europeanisering en het Bologna proces, kwam in het medisch onderwijs aandacht voor internationalisering van de opleiding. In de medisch onderwijskundige literatuur werd echter niet veel gepubliceerd over internationalisering van het onderwijs. De schaarse studies die er waren lieten niet toe er robuuste conclusies uit te trekken, vanwege de methodologische beperkingen van deze studies. Het was ook niet duidelijk hoe en of hedendaagse onderwijskundige theorieën over leren in de (klinische) werkplaats toegepast konden worden op internationalisering van het medisch onderwijs. Daarom formuleerden we een brede algemene onderzoeksvraag:

'Wat zijn de opleidingseffecten van internationalisering van de opleiding, voor het leren in de medische basis opleiding?'

Om deze algemene onderzoeksvraag te beantwoorden, zijn meer specifieke onderzoeksvragen geformuleerd. Deze specifieke onderzoeksvragen zijn gebaseerd op de bevindingen uit de studies, die tezamen dit proefschrift vormen. De specifieke onderzoeksvragen zijn:

- Welke aspecten van internationalisering kunnen worden onderscheiden aan de Nederlandse geneeskunde curricula?

- Wat leren studenten geneeskunde in de basisopleiding van buitenlandse stages?

- Wat is de aard van het leerproces van studenten geneeskunde in de basisopleiding, dat plaatsvindt wanneer deze studenten op een buitenlandse stage gaan?

- Beïnvloeden sociaal-culturele verschillen de aard van het leerproces, dat plaatsvindt wanneer studenten geneeskunde uit de basis opleiding op een buitenlandse stage gaan?

- Wat zouden leeruitkomsten moeten zijn van buitenlandse stages van studenten geneeskunde uit de basisopleiding?

De aard van de onderzoeksmethodologie die gehanteerd is bij de verschillende studies die tezamen dit proefschrift vormen kan gekarakteriseerd worden als Grounded Theory. 


\section{Chapter 2: State of Affairs}

In dit hoofdstuk wordt gerapporteerd over onderzoek dat poogt in kaart te brengen, wat de stand van zaken is met betrekking tot internationalisering van medisch basis onderwijs aan de Nederlandse geneeskunde opleidingen. De onderzoeksvragen waren: 1.Welke aspecten van internationalisering kunnen worden onderscheiden aan de Nederlandse geneeskunde curricula? 2.Wat is de omvang en de aard van studenten mobiliteit bij de Nederlandse geneeskunde opleidingen? 3.Hoe wordt de kwaliteit van buitenlandse studie onderdelen gewaarborgd? Een elektronische vragenlijst werd ingevuld door 7 (van de 8) coördinatoren van internationalisering van de Nederlandse geneeskunde opleidingen. Het bleek dat alle opleidingen aspecten van internationalisering van het onderwijs in het curriculum opgenomen hadden, in de meeste gevallen als keuzevak. Uitgaande studenten mobiliteit oversteeg in alle gevallen het aantal van inkomende mobiliteit en alle opleidingen besteden een zekere mate van aandacht het waarborgen van de kwaliteit van buitenlandse stages. In vier van de medische opleidingen werd geen aandacht besteed aan het trainen van vaardigheden in de omgang met patienten van verschillende sociaal-culturele achtergronden. Hetgeen beschouwd kan worden als een serieuze tekortkoming in de betreffende curricula. De bevindingen van dit onderzoek kunnen als representatief voor de Nederlandse situatie beschouwd worden.

\section{Chapter 3: What do students learn?}

In dit hoofdstuk worden aan de hand van zelfrapportages van studenten, leerervaringen van studenten van internationale stages gepresenteerd. Er zijn diepteinterviews gehouden met 24 studenten geneeskunde van de basisopleiding geneeskunde in Maastricht; deze studenten waren tenminste een maal op een buitenlandse stage geweest. De data werden verzameld en geanalyseerd met behulp van de 'constant vergelijkende methode' die overeenkomt met de 'open coding' en de 'axial coding' fase van de Grounded Theory methode.

Drie soorten stages werden beschreven door de studenten: oriënterende keuzevakken, onderzoeksstages en reguliere of keuze co-schappen. Verder beschreven studenten een brede reeks van leeruitkomsten en rapporteerden zij een brede reeks van problemen waar zij tegenaan liepen gedurende hun buitenlandse stage. Deze problemen waren: culturele problemen, politieke problemen, problemen met veranderingen in het stage programma, problemen met begeleiding, problemen ten gevolge van ziekte van de begeleider of de student, en persoonlijke problemen. De persoonlijke coping strategieën van de studenten bleken van belang in het omgaan met deze problemen. Verder lijken studenten die op een buitenlandse stage gaan een speciale, internationaal georiënteerde groep studen- 
ten te zijn (binnen de groep geneeskunde studenten). Bijvoorbeeld 17 van de 24 geïnterviewden bleek al eerdere buitenlandse ervaringen te hebben. De ongelijke verdeling van leeruitkomsten over de studenten kon niet verklaard worden door studiejaar, soort stage of het bezochte land.

\section{Chapter 4: Students' perceptions of their learning processes}

In dit onderzoek werd uitgegaan van de hypothese dat verschillen in de mate en aard van leeruitkomsten van buitenlandse stages tussen studenten, zou kunnen worden verklaard met het leerproces van studenten. Daarom analyseerden we opnieuw het rijke diepte-interview materiaal van de 24 studenten uit de Maastrichtse geneeskunde basis opleiding (van het onderzoek beschreven in hoofdstuk 3). De analyse resulteerde in een zestal categorieën gerelateerd aan het leerproces: motivatie, voorbereiding, interne begeleider (thuis universiteit), externe begeleider (buitenland), beoordeling, en positieve (bijvoorbeeld het oefenen van klinische vaardigheden) en negatieve incidenten (bijvoorbeeld de confrontatie met corruptie en laks gedrag binnen gezondheidszorg).

Onze bevindingen kwamen overeen met leerprocessen beschreven in de onderwijskundige literatuur onder 'New Learning'. Bij 'New Learning' worden een drietal leerprocessen onderscheiden: 'geleid leren'; 'zelf-gestuurd leren' en 'ervaringsleren'. Bij 'geleid leren' worden de leerfuncties: voorbereiding, uitvoering en evaluatie, gecontroleerd door de docent. Bij 'zelf-gestuurd leren' worden de leerfuncties gecontroleerd door de student. Bij 'ervaringsleren' is er geen controle over de leerfuncties, leren treedt op als een bijproduct van andere activiteiten. Het leerproces van de overgrote meerderheid van de geïnterviewde studenten kwam overeen met 'ervaringsleren'. Het ongestructureerde karakter van 'ervaringsleren' lijkt de variatie in leeruitkomsten tussen studenten te verklaren, omdat deze ongestructureerde leerprocessen tot welke leeruitkomst dan ook kunnen leiden.

Enkele studenten rapporteerden dat zij ontevreden waren over hun externe begeleider of zij hadden gemengde gevoelens over de externe begeleiding. We interpreteerden deze ervaringen (ten minste voor een deel) als het niet passen (mismatch) van de 'ervaringsinterface' tussen student en docent; deze zijn natuurlijk sterk gekleurd door sociaal-culturele contexten (bijvoorbeeld: weten dat binnen een bepaalde cultuur een verzoek weigeren als hoogst onbeleefd wordt ervaren, kan helpen de aansluiting te verbeteren.) 


\section{Chapter 5: Foreign supervisors' perceptions of students' learning processes}

In het hier beschreven onderzoek worden twee onderzoeksvragen behandeld: 1.Wat is de aard van het leerproces van geneeskunde studenten uit de basis opleiding tijdens buitenlandse stages? 2.Worden sociaal-culturele verschillen ervaren gedurende buitenlandse stages? Dit onderzoek is een triangulatie van onze bevindingen in een voorafgaand onderzoek (beschreven in hoofdstuk 4). In dit geval gebruiken we een andere bron voor de semi-gestructureerde interviews; in plaats van studenten interviewden we nu buitenlandse begeleiders.

Een 'multiple case-study, replication design' werd opgezet. De replicatie van de casus was gericht op de sociaal-culturele verschillen in de context van de stageplaatsen. Casus 1 omvat een stage plaats in de Outback van Australië $(\mathrm{n}=10)$; Casus 2 omvat stageplaatsen in stedelijk gebied van Australië $(n=3)$; casus 3 omvat stageplaatsen in Niet-Westerse landen (Kenia, Mexico, Filippijnen) $(\mathrm{n}=4)$.

De resultaten van dit onderzoek waren grotendeels consistent met de bevindingen uit het eerdere onderzoek met de studenten: de leerprocesen van de studenten werden voornamelijk beschreven als 'ervaringsleerprocessen' en hoe groter het verschil in nationale cultuur tussen student en begeleider, hoe hoger het aantal sociaal-culturele verschillen dat werd gerapporteerd door begeleiders. Het lijkt aannemelijk dat deze sociaal-culturele verschillen productief leren in de weg staan.

Gebaseerd op de onderzoeksresultaten bevelen we aan om te exploreren hoe de sociaal-culturele verschillen te transformeren van potentiële belemmeringen naar een positief onderdeel van de leerervaring van studenten. Bovendien wordt aanbevolen om 'zelf-gestuurde' en 'geleide leerprocessen' te bevorderen, als toevoeging op 'ervaringsleerprocessen' in buitenlandse stages.

De stevigheid van de conclusies in dit onderzoek is beperkt door een potentieel effect van sociale wenselijkheid in de interviews met de buitenlandse begeleiders.

\section{Chapter 6: What should be learning outcomes?}

Om structuur in leerprocessen aan te brengen (om 'zelf-gestuurde' en 'geleide leerprocessen' te stimuleren) is een minimale vereiste leeruitkomsten te hebben vastgesteld. Om gewenste leeruitkomsten voor leren in buitenlandse stages vast te stellen, werd een Delphi procedure uitgevoerd onder een panel van internationale experts. Stabiliteit werd bereikt na twee rondes (ronde $1 \mathrm{n}=55$; ronde 2 $\mathrm{n}=36$ ). 
Een raamwerk van leeruitkomsten dat werd ontwikkeld in een voorafgaand onderzoek (om leeruitkomsten gerapporteerd door studenten te categoriseren, zie hoofdstuk 3) werd als uitgangspunt gebruikt. Met behulp van het advies van een internationaal panel van experts werd het verder ontwikkeld en gevalideerd in een raamwerk van gewenste leeruitkomsten van buitenlandse stages voor Nederlandse studenten uit de basis opleiding geneeskunde. Het raamwerk omvat de volgende domeinen: medische kennis, klinische vaardigheden, communicatie vaardigheden, interculturele vaardigheden, academische ontwikkeling, gezondheidszorg in het bezochte land, kennis over cultuur en maatschappij van het bezochte land, persoonlijk groei en professionele ontwikkeling.

Het wordt aanbevolen om het raamwerk te gebruiken door zowel studenten als docenten om leerdoelen uit te formuleren. Het raamwerk is opgebouwd volgens de traditionele onderverdeling in kennis, vaardigheden en attitudes. Deze geïsoleerde domeinen zouden kunnen worden getransformeerd naar meer geïntegreerde competenties.

Hoewel het internationale panel bestaat uit een indrukwekkende groep mensen, is het niet zeker dat we in staat geweest zijn om alle relevante experts uit het veld te betrekken in het panel. Bijvoorbeeld zijn we niet in staat geweest om een groep mobiliteitsonderzoekers plaats te laten nemen in het panel.

\section{Chapter 7: A preliminary Grounded Theory}

In het hier gerapporteerde onderzoek worden de bevindingen van vijf empirische onderzoekingen geïntegreerd. Deze onderzoekingen werden alle uitgevoerd in het kader van dit proefschrift en zijn beschreven in voorafgaande hoofdstukken. Tezamen vormen ze een inleidende Grounded Theory over leren van buitenlandse stages door geneeskunde studenten in de basis opleiding. Het integreren van deze onderzoekingen preludeert op de finale fase van de Grounded Theory methode.

Een 'kern categorie' (het gevoel erbij te horen) werd vastgesteld en geïntegreerd met de 'centrale categorieën' (begeleiding, leerprocessen, leeruitkomsten). De 'kern categorie' (het gevoel erbij te horen) laat zien hoe een positief sociaal klimaat door de betrokkenheid in de praktijk het leren van studenten stimuleert. Tegelijkertijd verstoort het gevoel 'er maar matig bij te horen' het leren van studenten. Gebaseerd op de inleidende Grounded Theory wordt aanbevolen om het gevoel erbij te horen op de stage plaats van studenten te versterken, door meer structuur aan te brengen in hun leerprocessen. Dit vraagt om additionele (meta-cognitieve) vaardigheden van zowel studenten als docenten. Een andere manier om het gevoel van erbij te horen te verstevigen door het aanbrengen van structuur in hun leerprocessen, is het invoeren van studiegidsen. 
Het hier gepresenteerde onderzoek komt overeen met de laatste fase van Grounded Theory. Om het volledig af te ronden zou de theorie getest moeten worden met behulp van nieuwe data.

\section{Chapter 8: Conclusion and Discussion}

In dit hoofdstuk worden de belangrijkste conclusies bediscussieerd. Vervolgens worden aanbevelingen voor de praktijk en verder onderzoek gepresenteerd. Het hoofdstuk wordt afgesloten met een bespreking van de beperkingen van het in het kader van dit proefschrift uitgevoerde onderzoek.

In dit proefschrift hebben we geprobeerd een antwoord te formuleren op de algemene onderzoeksvraag:

'Wat zijn de opleidingseffecten van internationalisering van de opleiding, voor het leren in de medische basis opleiding?'

Ons antwoord op deze algemene onderzoeksvraag is: we concluderen dat leren van buitenlandse stages in potentie leren is in een krachtige leeromgeving, waar studenten nieuwe kennis, vaardigheden en attitudes kunnen verwerven in een context met authentieke complexe taken. De brede reeks van door studenten gerapporteerde leeruitkomsten omvat gewenste leeruitkomsten van de medische basis opleiding.

We bevelen aan om het leren van buitenlandse stages nog productiever te maker door een verbetering van het gevoel erbij te horen op de stageplaats van de student. Om dit te bereiken, raden we aan meer structuur te brengen in de leerprocessen van de studenten door: verhogen van 'zelf-gestuurd leren', door gebruik te maken van 'independent work' en door het verhogen van 'geleide leerprocessen' en door het trainen van coping stijlen van studenten.

Vervolg onderzoek zou al de hierboven aangegeven aanbevelingen voor de praktijk kunnen evalueren. Verder zou vervolg onderzoek zich kunnen richten op het exploreren van mogelijkheden om het leren van studenten in buitenlandse stages te beoordelen. Het is ook interessant om te onderzoeken hoe deze beoordelingen een rol zouden kunnen spelen in kwaliteitszorg.

Doordat het in dit proefschrift beschreven onderzoek zich geconcentreerd heeft op buitenlandse stages, kunnen we slechts een deel van de algemene onderzoeksvraag beantwoorden. Daarom bevelen we aan om vervolgonderzoek te richten op 'Internationalisation at Home', met inbegrip van inwaarts gerichte mobiliteit. Ondanks onze pogingen om de kwaliteit van de onderzoeksmethodologie en de onderzoeksbevindingen te waarborgen, zijn er toch beperkingen aan de conclusies uit dit kleinschalige onderzoek. We bevelen aan de hier gepresenteerde bevindingen te testen in representatieve steekproeven in verschillende nationale culturele contexten. 


\section{Dankwoord}

Aan het begin van mijn promotie traject kon ik niet voorzien waar ik aan begon. Gelukkig maar! Uiteindelijk ligt hier dan toch een boekje; het beschrijft echter slechts een deel van alle opgedane ervaringen. Op deze plaats wil ik iedereen bedanken die met mij het traject geheel of voor een gedeelte meegelopen is!

Ik had het voorrecht bij het schrijven van mijn proefschrift van begin tot eind vergezeld te worden door een illuster driemanschap: Cees van der Vleuten, Albert Scherpbier en Gerard Majoor. Cees ik dank je dat ik in jouw schaduw heb mogen leren en dat ik van jou 'de kunst heb mogen afkijken'. Gerard ik bewonder je om het enthousiasme waarmee je al zovele jaren strijd voert voor internationalisering, en ik dank je voor de humor waarmee je altijd alles relativeert. Albert, dank voor je geruststellende gemoedelijkheid en de zekerheid dat alles goed zal komen en je vermogen om altijd weer vanuit een nieuw perspectief naar iets te kijken.

Ik bedank iedereen die aan mijn onderzoek heeft meegewerkt door het geven van interviews en het invullen van vragenlijsten. Zonder jullie was het onderzoek niet tot stand gekomen!

Aan het begin van mijn AIOschap in 2001 heb ik een jaar onderdak gehad bij het Bureau Internationale Betrekkingen. Ik dank alle medewerkers van het $\mathrm{Bu}$ reau voor de gezellige werksfeer. In het bijzonder bedank ik Marion Aarts en Astrid Peters voor jullie belangstelling voor het onderzoek en jullie hulp bij het aanleveren van gegevens voor het samenstellen van steekproeven.

Vanuit het Bureau Internationale Betrekkingen verhuisde ik naar de capaciteitsgroep Onderwijsontwikkeling \& Research. Ik bedank alle medewerkers van de capaciteitsgroep voor de stimulerende werksfeer. In het bijzonder bedank ik Diana Dolmans, Mereke Gorsira, Lilian Swaen en Ineke Wolfhagen voor jullie interesse en de raad en daad waarmee jullie mij altijd bijstonden.

Door mijn verhuizing naar de capaciteitsgroep Onderwijsontwikkeling \& Research participeerde ik (nog meer) in het promovendi netwerk. Ik heb mooie herinneringen aan de constructieve contacten met alle onderwijskunde AIO's, AIOTHO's en andere promovendi die tezamen dit netwerk vormden. In het bijzonder bedank ik Wemke Veldhuijzen, Renée Stalmeijer, Theo Niessen, Dineke Tigelaar en Astrid Visschers-Pleijers.

Een gedeelte van mijn onderzoek heb ik in Australië gedaan. 
I thank all international respondents for giving their time for interviews. I thank the people from the Department for Rural Health, University of Sydney at Broken Hill, NSW Australia for their kind help with the organization of the interviews and their warm welcome. Especially I would like to thank Jocelyn Morris and Professor David Lyle for their help and kind attention.

Mijn vader en moeder bedank ik omdat zij er altijd voor mij zijn en omdat zij mij altijd gestimuleerd hebben me te ontwikkelen.

Last but not least: dit proefschrift is mede tot stand gekomen dankzij de levensvreugde van mijn dwergpinscher Jamie. Zijn glimlach maakt altijd alles de moeite waard. 


\section{Curriculum Vitae}

Susan Niemantsverdriet was born on the $28^{\text {th }}$ of November, 1960, in Rotterdam, the Netherlands. In 1977 she finished secondary education. In 1981 she completed her in-service training as a psychiatric nurse, in The Hague, the Netherlands. Subsequently she spent six months in Crete, Greece, where she gained a vast amount of experience in dishwashing. In 1983 she completed the first year in Social Work Studies, University of Applied Sciences, Breda, the Netherlands. Susan obtained a Master's Degree in Sociology in 1990, from Utrecht University, the Netherlands. Subsequently she lived several years near Aachen, Germany, where she amongst other things supported her Dutch husband building up a dental praxis.

In the middle of the nineties (after her divorce) she moved back to the Netherlands, where she had a teaching appointment in the Department of Medical Sociology, Faculty of Health Sciences, Maastricht University from 1991 till 1998, and where she was immersed in problem-based learning. Between 1993 and 2001 she also participated in several research projects at Maastricht University, in the areas of home care, palliative care, gender studies, international education and special education (Vrije School). From 1998 to 2000 she coordinated an international education project on 'Public Health for Primary Health Care Physicians of Egypt' at Mundo Bureau, Maastricht University, the Netherlands.

Since 2001, Susan has worked on a project for her PhD thesis, entitled 'Learning from international internships: A reconstruction in the medical domain', at the Department of Educational Development and Research at the Maastricht University. Currently she works as a Project Leader of Internationalisation in the University of Applied Sciences, Leiden, the Netherlands. 


\section{ICO Dissertation Series}

In the ICO Dissertation Series dissertations are published of graduate students from faculties and institutes on educational research within the following universities: University of Twente, University of Groningen, Maastricht University, University of Amsterdam, Utrecht University, Open University, Leiden University, Wageningen University, Technical University of Eindhoven, and Free University (and formerly University of Nijmegen and University of Tilburg). Over one hundred dissertations have been published in this series. The most recent ones are listed below.

114. Kuijpers, M.A.C.T. (21-03-2003). Loopbaanontwikkeling: onderzoek naar 'Competenties'. Enschede: University of 'Twente.

115. Jepma, IJ. (01-07-2003). De schoolloopbaan van risico-leerlingen in het primair onderwijs. Amsterdam: University of Amsterdam.

116. Sotaridona, L.S. (05-09-2003). Statistical Methods for the Detection of Answer Copying on Achievement Tests. Enschede: University of Twente.

117. Kester, L. (05-09-2003). Timing of Information Presentation and the Acquisition of Complex Skills. Heerlen: Open University.

118. Waterreus, J.M. (05-09-2003). Lessons in Teacher Pay: Studies on Incentives and the Labor Market for Teachers. Amsterdam: University of Amsterdam.

119. Toolsema, B. (23-10-2003). Werken met competenties. Enschede: University of Twente.

120. Taks, M.M.M.A. (20-11-2003). Zelfsturing in leerpraktijken: Een curriculumonderzoek naar nieuwe rollen van studenten en docenten in de lerarenopleiding. Enschede: University of Twente.

121. Driessen, C.M.M. (21-11-2003). Analyzing Textbook Tasks and the Professional Development of Foreign Language Teachers. Utrecht: Utrecht University.

122. Hubers, S.T.T. (24-11-2003). Individuele leertheorieën en het leren onderzoeken in de tweede fase. Eindhoven: Technical University of Eindhoven.

123. Sun, H. (04-12-2003). National Contexts and Effective School Improvement: An Exploratory Study in Eight European Countries. Groningen: University of Groningen.

124. Bruinsma, M. (09-12-2003). Effectiveness of Higher Education: Factors that Determine Outcomes of University Education. Groningen: University of Groningen. 
125. Veneman, H. (01-07-2004). Het gewicht van De Rugzak: Evaluatie van het beleid voor leerlinggebonden financiering. Groningen: University of Groningen.

126. Annevelink, E. (27-08-2004). Class Size: Linking Teaching and Learning. Enschede: University of Twente.

127. Emmerik, M.L. van (22-09-2004). Beyond the Simulator: Instruction for High Performance Tasks. Enschede: University of Twente.

128. Vries, B. de (15-10-2004). Opportunities for Reflection: E-mail and the Web in the Primary Classroom. Enschede: University of Twente.

129. Veenhoven, J. (05-11-2004). Begeleiden en beoordelen van leerlingonderzoek: Een interventiestudie naar het leren ontwerpen van onderzoek in de tweede fase van het voortgezet onderwijs. Utrecht: Utrecht University.

130. Strijbos, J.W. (12-11-2004). The Effect of Roles on Computer-Supported Collaborative Learning. Heerlen: Open University.

131. Hamstra, D.G. (22-11-2004). Gewoon en Anders: Integratie van leerlingen met beperkingen in het regulier onderwijs in Almere. Groningen: University of Groningen.

132. Lubbers, M.J. (09-12-2004). The Social Fabric of the Classroom: Peer Relations in Secondary Education. Groningen: University of Groningen.

133. Nijman, D.J.J.M. (10-12-2004). Supporting Transfer of Training: Effects of the Supervisor. Enschede: University of Twente.

134. Dewiyanti, S. (25-02-2005). Learning Together: A positive experience. The effect of reflection on group processes in an asynchronous computer-supported collaborative learning environment. Heerlen: Open University.

135. Stoof, A. (04-03-2005). Tools for the identification and description of competencies. Heerlen: Open University.

136. Groot, R.W.A. de (10-03-2005). Onderwijsdecentralisatie en lokaal beleid. Amsterdam: Universiteit van Amsterdam.

137. Salden, R.J.C.M. (22-04-2005). Dynamic Task Selection in Aviation Training. Heerlen: Open University.

138. Huong, N.T. (23-05-2005). Vietnamese learners mastering English articles. Groningen: University of Groningen.

139. Gijlers, A.H. (23-09-2005). Confrontation and co-construction: Exploring and supporting collaborative scientific discovery learning with computer simulations. Enschede: University of Twente.

140. Stevenson, M.M.C. (27-09-2005). Reading and writing in a foreign language: A comparison of conceptual and linguistic processes in Dutch and English. Amsterdam: University of Amsterdam.

141. Saab, N. (14-10-2005). Chat and explore: The role of support and motivation in collaborative scientific discovery learning. Amsterdam: University of Amsterdam. 
142. Löhner, S. (11-11-2005). Computer-based modeling tasks: The role of external representation. Amsterdam: University of Amsterdam.

143. Beers, P.J. (25-11-2005). Negotiating common ground: Tools for multidisciplinary teams. Heerlen: Open University.

144. Tigelaar, E.H. (07-12-2005). Design and evaluation of a teaching portfolio. Maastricht: University of Maastricht

145. Van Drie, J.P., (20-12-2005). Learning about the past with new technologies. Fostering historical reasoning in computer-supported collaborative learning. Utrecht: Utrecht University.

146. Walrecht, E.S. (09-01-2006). Brede innovatie, passende strategie?: De Groninger Vensterschool als casus van onderzoek naar strategie en invoering: Groningen University of Groningen

147. De Laat, M. (03-02-2006). Networked learning. Utrecht: University of Utrecht.

148. Prince, C.J.A.H. (21-04-2006). Problem-based learning as a preparation for professional practice. Maastricht: University of Maastricht.

149. Van Gog, T. (28-04-2006). Uncovering the problem-solving process to design effective worked examples. Heerlen: Open University.

150. Sins, P.H.M. (18-05-2006). Students' reasoning during computer-based scientific modeling. Amsterdam: University of Amsterdam.

151. Mathijsen, I.C.H. (24-05-2006). Denken en handelen van docenten. Utrecht: Utrecht University.

152. Akkerman, S.F. (23-06-2006). Strangers in dialogue: Academic collaboration across organizational boundaries. Utrecht: Utrecht University.

153. Willemse, T.M. (21-08-2006). Waardenvol opleiden: Een onderzoek naar de voorbereiding van aanstaande leraren op hun pedagogische opdracht. Amsterdam: Free University of Amsterdam.

154. Kieft, M. (19-09-2006). The effects of adapting writing instruction to students' writing strategies. Amsterdam: University of Amsterdam.

155. Vreman-de Olde, G.C. (27-09-2006). Look Experiment Design: Learning by designing instruction. Enschede: University of Twente.

156. Van Amelsvoort, M. (13-10-2006). A space for debate: How diagrams support collaborative argumentation-based learning. Utrecht: Utrecht University.

157. Oolbekking-Marchand, H. (9-11-2006). Teachers' perspectives on selfregulated learning: An exploratory study in secondary and university education. Leiden: Leiden University.

158. Gulikers, J. (10-11-2006). Authenticity is in the eye of the beholder: Beliefs and perceptions of authentic assessment and the influence on student learning. Heerlen: Open University of the Netherlands.

159. Henze, I. (21-11-2006). Science teachers' knowledge development in the context of educational innovation. Leiden: Leiden University. 
160. Van den Bossche, P. (29-11-2006). Minds in teams: The influence of social and cognitive factors on team learning: Maastricht: University of Maastricht.

161. Mansvelder-Longayroux, D.D. (06-12-2006). The learning portfolio as a tool for stimulating reflection by student teachers. Leiden: Leiden University.

162. Visschers-Pleijers, A.J.S.F. (19-01-2007). Tutorial group discussion in problem-based learning: Studies on the measurement and nature of learning-oriented student interactions. Maastricht: University of Maastricht.

163. Poortman, C.L. (16-02-2007). Workplace learning processes in senior secondary vocational education. Enschede: University of Twente. 